\title{
RESPOSTA DO MARACUJAZEIRO AMARELO (Passiflora edulis Sins var. flavicarpa Deg) A LÂMINAS DE IRRIGAÇÃ̃O E DOSES DE ADUBAÇÃO POTÁSSICA
}

\author{
ARIOVALDO ANTONIO TADEU LUCAS
}

Dissertação apresentada à Escola Superior de Agricultura "Luiz de Queiroz”, Universidade de São Paulo, para obtenção do título de Mestre em Agronomia, Área de concentração: Irrigação e Drenagem.

PIRACICABA

Estado de São Paulo - Brasil

Março - 2002 


\title{
RESPOSTA DO MARACUJAZEIRO AMARELO (Passiflora edulis Sins var. flavicarpa Deg) A LÂMINAS DE IRRIGAÇÃ̃O E DOSES DE ADUBAÇÃO POTÁSSICA
}

\section{ARIOVALDO ANTONIO TADEU LUCAS}

Engenheiro Agrônomo

\author{
Orientador: Prof. Dr. JOSÉ ANTONIO FRIZZONE
}

Dissertação apresentada à Escola Superior de Agricultura "Luiz de Queiroz", Universidade de São Paulo, para obtenção do título de Mestre em Agronomia, Área de concentração: Irrigação e Drenagem.

PIRACICABA

Estado de São Paulo - Brasil

Março - 2002 


\section{Dados I nternaci onai s de Catal ogação na Publ i cação ( CI P) DI VI SÃo DE BI BLI OTECA E DOCUMENTAÇÃO - ESALQ/ USP}

Lucas, Ariovaldo Antonio Tadeu

Resposta do maracujazeiro amarelo (Passiflora edulis Sins var. flavicarpa Deg) a

lâminas de irrigação e doses de adubação potássica / Ariovaldo Antonio Tadeu Lucas.

- - Piracicaba, 2002.

$84 \mathrm{p}$.

Dissertação (mestrado) - - Escola Superior de Agricultura Luiz de Queiroz, 2002.

Bibliografia.

1. Fertilizantes potássicos 2. Fertirrigação 3. Irrigação por gotejamento 4.

Maracujá I. Título

CDD 634.425

"Permitida a cópia total ou parcial deste documento, desde que citada a fonte - O autor" 
A Deus, pela vida, saúde e paz, por sua presença em todos os momentos de minha existência.

AGRADEÇO

\author{
A meus pais Orlando Lucas e Maria Bicudo Lucas \\ que sempre me apoiaram e pelo sacrifício e \\ dificuldades que passaram em prol da educação e \\ formação de seus filhos; \\ Aos meus irmãos, sobrinhos e cunhadas \\ pelo apoio e alegria que proporcionam.
}

DEDICO

A todos que acreditaram em mim. OFEREÇO. 


\section{AGRADECIMENTOS}

Ao Departamento de Engenharia Rural da Escola Superior de Agricultura "Luiz de Queiroz"/USP, pela oportunidade concedida para a realização do curso;

À Fundação de Amparo à Pesquisa do Estado de São Paulo/FAPESP, pela concessão da bolsa de estudos;

Ao Prof. Dr. José Antonio Frizzone pela orientação e estímulo dado para desenvolver este trabalho e pelo convívio amistoso durante o curso;

Aos Professores do curso de Pós-graduação em Irrigação e Drenagem pelos ensinamentos;

Aos professores Dr. Rubens Duarte Coelho, Dr. Sergio Nascimento Duarte, Dr. Tarlei Arriel Botrel e ao Dr. Anderson Soares Pereira pelas valiosas sugestões na execução do experimento, nas análises dos dados e na elaboração da dissertação;

Ao Prof. Dr. José Geanini Peres do Departamento de Recursos Naturais e Proteção Ambiental do Centro de Ciências Agrárias da UFSCar, Araras, SP, pelo incentivo e apoio moral no início da minha vida científica;

Ao colega Flávio Favaro Blanco pelo auxílio na elaboração do SUMMARY;

Aos colegas do Curso de Pós-Graduação em Irrigação e Drenagem: Adriano José Soares, Maurício A. Coelho Filho, Wellington Farias de Araújo, Leonardo Duarte Batista da Silva, Carmello Crisafulli Machado, Jocelito Saccol de Sá, Luis Fernando Faria, Rodrigo Otávio Rodrigues de Melo Souza e Olívio José Soccol pelas valiosas idéias e colaborações na execução do experimento e análise dos dados;

Aos demais Colegas do Curso de Pós-Graduação em Irrigação e Drenagem, pela amizade e apoio durante o curso; 
Ao Colega de profissão Eng. Agr. Rodrigo Alessandro de Lima Corrêa e ao Dr. Valdemício Ferreira de Sousa, da Embrapa Meio-Norte, pela colaboração durante a condução do experimento e coleta dos dados experimentais;

Aos funcionários do Departamento de Engenharia Rural, pelo apoio durante a realização do curso e na execução do experimento;

Aos estudantes do curso de graduação em Engenharia Agronômica da ESALQ/USP, Estagiários do Grupo de Práticas em Irrigação e Drenagem (GPID), pela colaboração na condução do experimento;

A todos aqueles que de alguma forma contribuíram para que esse trabalho fosse realizado. 


\section{SUMÁRIO}

Página

LISTA DE FIGURAS …......................................................................... viii

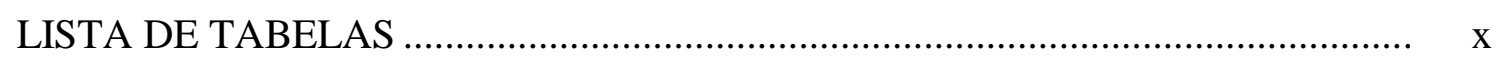

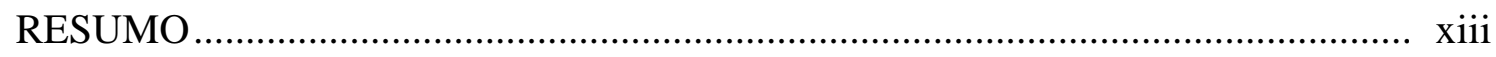

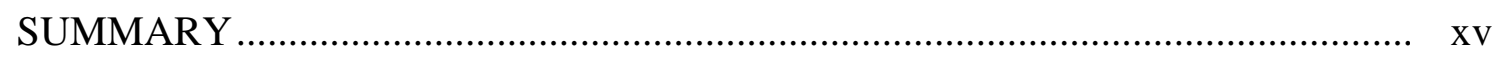

1 INTRODUÇÃ

2 REVISÃO DE LITERATURA ..................................................................... 4

2.1 Características agronômicas da cultura do maracujazeiro ................................... 4

2.2 Irrigação e fertirrigação ............................................................................. 13

3 MATERIAL E MÉTODOS ............................................................................ 19

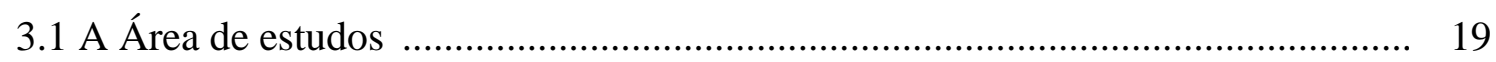

3.2 Delineamento experimental .................................................................... 23

3.3 Principais características do experimento ..................................................... 26

3.3.1 Histórico do experimento ................................................................... 26

3.4 Irrigação e fertilização.............................................................................. 27

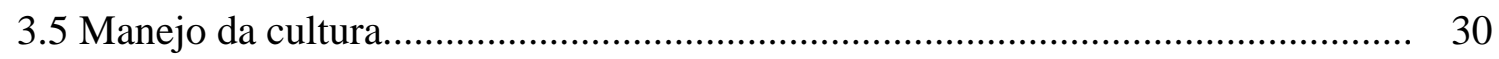

3.6 Parâmetros avaliados..................................................................................... 32

3.6.1 Estado nutricional das plantas ................................................................ 33

3.6.2 Colheita, produtividade e classificação de frutos........................................... 33

3.6.3 Parâmetros de qualidade de frutos ............................................................ 34

3.6.4 Parâmetros de desenvolvimento das plantas ............................................. 35

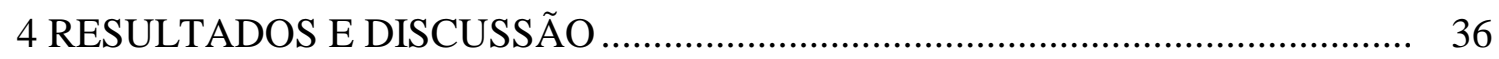


4.1 Manejo da irrigação .............................................................................. 36

4.2 Condutividade elétrica da solução do solo.......................................................... 38

4.3 Concentração de potássio no solo ..................................................................... 40

4.4 Diâmetro de caule e comprimento de internós....................................................... 42

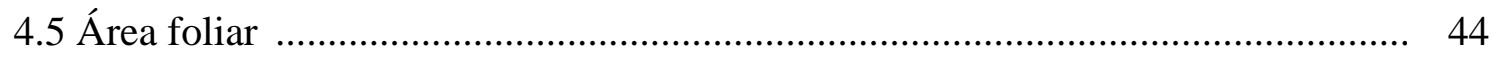

4.6 Sistema radicular ............................................................................. 45

4.7 Características químicas dos frutos ............................................................... 46

4.8 Características físicas dos frutos ................................................................. 51

4.9 Estado nutricional ........................................................................... 58

4.9.1 Concentrações foliares de macronutrientes....................................................... 58

4.9.2 Concentrações foliares de micronutrientes ................................................... 65

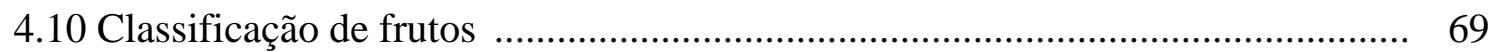

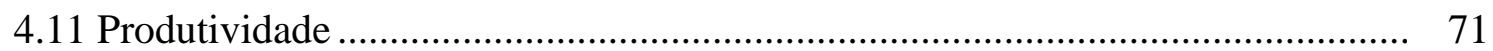

4.11.1 Produtividade comercial ........................................................................ 72

4.11.2 Produtividade não comercial..................................................................... 74

4.11.3 Produtividade total ............................................................................... 76

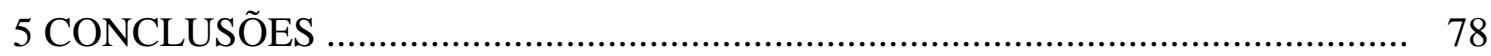

REFERÊNCIAS BIBLIOGRÁFICAS _................................................................ 80 


\section{LISTA DE FIGURAS}

Página

1 Curvas de retenção de água no solo da área experimental para a camada (a) $0,00-0,10 \mathrm{~m}$; (b) $0,10-0,30 \mathrm{~m}$; (c) $0,30-0,50 \mathrm{~m} \mathrm{e}$ (d) $0,50-0,70 \mathrm{~m} \ldots \ldots \ldots .$.

2 Detalhe do sistema de irrigação (ao redor da planta) e fertirrigação (linha longitudinal)

3 Vista das plantas antes da poda aos 410 DAT (a) e plantas aos 500 DAT após a poda de renovação (b)

4 Condutividade elétrica da solução do solo nos tratamentos

5 Concentração de potássio na solução do solo

6 Efeito de doses de potássio e lâminas de irrigação na concentração de nitrogênio nas folhas do maracujazeiro amarelo

7 Efeito de doses de potássio e lâminas de irrigação na concentração de fósforo nas folhas do maracujazeiro amarelo

8 Efeito de doses de potássio e lâminas de irrigação na concentração de potássio nas folhas do maracujazeiro amarelo

9 Efeito de doses de potássio e lâminas de irrigação na concentração de cálcio nas folhas do maracujazeiro amarelo.

10 Efeito de doses de potássio e lâminas de irrigação na concentração de magnésio nas folhas do maracujazeiro amarelo

11 Efeito de doses de potássio e lâminas de irrigação na concentração de enxofre nas folhas do maracujazeiro amarelo 
12 Efeito de doses de potássio e lâminas de irrigação na concentração de boro nas folhas do maracujazeiro amarelo

13 Efeito de doses de potássio e lâminas de irrigação na concentração de cobre nas folhas do maracujazeiro amarelo

14 Efeito de doses de potássio e lâminas de irrigação na concentração de ferro nas folhas do maracujazeiro amarelo

15 Efeito de doses de potássio e lâminas de irrigação na concentração de manganês nas folhas do maracujazeiro amarelo.

16 Efeito de doses de potássio e lâminas de irrigação na concentração de zinco nas folhas do maracujazeiro amarelo....

17 Curva de produtividade não comercial média do maracujazeiro amarelo em função das doses de potássio 


\section{LISTA DE TABELAS}

Página

1 Resultados de análises químicas do solo da área experimental: $\mathrm{pH}$, matéria orgânica (M.O), macronutrientes, soma de base (SB), capacidade de troca de cátions (T) e saturação por bases $(\mathrm{V})$.

2 Resultados de análises químicas de micronutrientes do solo da área experimental: Boro (B), cobre $(\mathrm{Cu})$, ferro $(\mathrm{Fe})$, manganês $(\mathrm{Mn})$ e zinco $(\mathrm{Zn})$.. 20

3 Valores de densidade global, teores de argila, silte e areia de amostras de solo da área experimental

4 Resultados das análises químicas de água da barragem localizada na Fazenda Areão, utilizada para a irrigação.

5 Valores médios mensais de radiação global (RG), número de horas de insolação, precipitação pluviométrica $(\mathrm{P})$, umidade relativa do ar (UR), velocidade média do vento a $2 \mathrm{~m}$ de altura $\left(\mathrm{U}_{2}\right)$ e temperatura média do ar (T) no período de maio de 2000 a abril de 2001

6 Valores percentuais de acúmulo de nitrogênio $(\mathrm{N})$ e potássio $\left(\mathrm{K}_{2} \mathrm{O}\right)$ pelo maracujazeiro na fase de produção

7 Esquema da análise de variância para o delineamento experimental de blocos ao acaso com parcelas subdivididas.

8 Quantidades de nutrientes aplicados de acordo com a análise de solo

9 Pulverizações realizadas durante a condução do experimento para o controle de pragas e doenças.

10 Lâminas mensais de irrigação $(\mathrm{mm})$ aplicadas durante o experimento

11 Valores médios de umidade do solo 
12 Resumo da análise de variância para características morfológicas: diâmetro de caule e comprimento de internós do maracujazeiro amarelo ...................... 42

13 Valores médios de diâmetro de caule do maracujazeiro amarelo $(\mathrm{mm})$............. 43

14 Valores médios de comprimento de internós $(\mathrm{mm})$....................................... 43

15 Resumo da análise de variância para a característica morfológica área foliar do maracujazeiro amarelo .................................................................. 44

16 Valores médios de área foliar do maracujazeiro amarelo $\left(\mathrm{m}^{2}\right.$ planta $\left.^{-1}\right) \ldots \ldots \ldots \ldots \ldots . .45$

17 Distribuição percentual do sistema radicular do maracujazeiro amarelo .......... 46

18 Resumo da análise de variância para as características químicas do

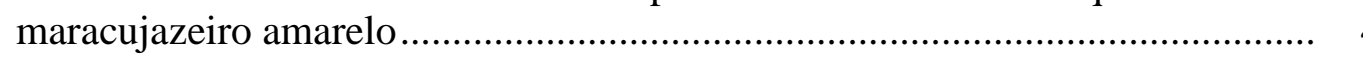

19 Valores médios de teores de sólidos solúveis totais (SS, \%de ${ }^{\circ}$ Brix) em frutos de maracujazeiro amarelo ........................................................ 48

20 Valores médios da acidez total titulável dos frutos de maracujá amarelo ........ 49

21 Valores médios do pH para frutos de maracujá amarelo .............................. 50

22 Resumo da análise de variância para as características físicas do maracujazeiro amarelo (densidade do suco ,espessura da casca e rendimento de suco)

23 Resumo da análise de variância para as características físicas do fruto do maracujazeiro amarelo (peso de fruto, diâmetro e comprimento de fruto)......... 52

24 Valores médios da densidade do suco $\left(\mathrm{g} \cdot \mathrm{cm}^{-3}\right)$ de maracujá amarelo ................ 53

25 Valores médios da espessura da casca $(\mathrm{mm})$ de frutos de maracujá amarelo..... 54

26 Valores médios de rendimento de suco de frutos (\%) de maracujá amarelo .... 54

27 Valores médios do peso de fruto $(\mathrm{g})$ de maracujazeiro amarelo....................... 55

28 Valores médios do diâmetro de fruto $(\mathrm{mm})$ de maracujazeiro amarelo.............. 56 
29 Valores médios de comprimento do fruto $(\mathrm{mm})$ de maracujazeiro amarelo .......

30 Resumo da análise de variância para concentração de macronutrientes (N, P e K)

31 Resumo da análise de variância para concentração de macronutrientes $(\mathrm{Ca}$, $\mathrm{Mg}$ e S.

32 Resumo da análise de variância para concentração de micronutrientes $(\mathrm{B}, \mathrm{Cu}$ $\mathrm{e} \mathrm{Fe})$

33 Resumo da análise de variância para concentração de micronutrientes (Mn, e $\mathrm{Zn})$

34 Classificação dos frutos comerciais colhidos

35 Distribuição mensal da produtividade comercial $\left(\mathrm{kg} \cdot \mathrm{ha}^{-1}\right)$ do maracujazeiro durante o período de colheita

36 Resumo da análise de variância para produtividade comercial (PC), produtividade não comercial (PNC) e produtividade total (PT) do maracujazeiro amarelo cultivado sob diferentes níveis de irrigação com doses de potássio aplicadas via fertirrigação

37 Produtividade comercial $\left(\mathrm{kg} \mathrm{ha}^{-1}\right)$ do maracujazeiro cultivado sob diferentes níveis de irrigação e doses de potássio aplicadas via fertirrigação

38 Produtividade não comercial $\left(\mathrm{kg} \mathrm{ha}^{-1}\right)$ do maracujazeiro cultivado sob diferentes níveis de irrigação e doses de potássio via fertirrigação .

39 Produtividade total $\left(\mathrm{kg} \mathrm{ha}^{-1}\right)$ do maracujazeiro amarelo cultivado sob diferentes níveis de irrigação e doses de potássio aplicadas via fertirrigação .... 


\title{
RESPOSTA DO MARACUJAZEIRO AMARELO (Passiflora edulis Sins var. flavicarpa Deg.) A LÂMINAS DE IRRIGAÇÃO E DOSES DE ADUBAÇÃO POTÁSSICA
}

\author{
Autor: ARIOVALDO ANTONIO TADEU LUCAS \\ Orientador: Prof. Dr. JOSÉ ANTONIO FRIZZONE
}

\section{RESUMO}

Com o objetivo de estudar o efeito de lâminas de irrigação e doses de potássio aplicadas via fertirrigação por gotejamento no desenvolvimento, na produtividade e na qualidade de frutos do maracujazeiro amarelo (Passiflora edulis Sins var. flavicarpa Deg) conduziu-se um experimento no período de maio de 2000 a maio de 2001, segundo ciclo da cultura, no campo experimental pertencente ao Departamento de Engenharia Rural da ESALQ/USP, Piracicaba, São Paulo. O experimento foi conduzido em 3 blocos casualizados com parcelas subdivididas em 5 tratamentos de adubação potássica, com doses de $\mathrm{K}_{2} \mathrm{O}$ variando de zero (testemunha) até $0,800 \mathrm{~kg}$ de $\mathrm{K}_{2} \mathrm{O}$ por planta, aplicados fracionadamente via fertirrigação por gotejamento e 4 lâminas de irrigação, que variaram de 63,3 a 220,5 mm, definidas como frações da lâmina média evapotranspirada 
medida em quatro lisímetros de drenagem. Concluiu-se que houve efeito significativo das lâminas de irrigação sobre o diâmetro do caule e a área foliar do maracujazeiro amarelo. Não houve efeito dos tratamentos nos comprimentos de internós. O peso do fruto, a densidade do suco, a espessura da casca e o rendimento do suco foram influenciados significativamente pelas lâminas de irrigação, pelas doses de potássio e pela interação entre esses fatores. Não houve efeito significativo dos tratamentos sobre os sólidos solúveis totais, $\mathrm{pH}$ e acidez total titulável do suco. O comprimento de fruto foi afetado significativamente pela interação entre lâminas de irrigação e doses de potássio e não houve efeito significativo dos tratamentos no diâmetro de fruto. As concentrações foliares de potássio, magnésio e manganês foram influenciadas significativamente pelas lâminas de irrigação e pelas doses de potássio e as concentrações foliares de boro e ferro sofreram efeito significativo apenas da interação entre as lâminas de água e as doses de potássio. Não houve efeito significativo dos tratamentos sobre as concentrações foliares de nitrogênio, fósforo, cálcio, enxofre, cobre e zinco. Houve efeito significativo dos tratamentos na produção comercial, apresentando um valor máximo de $14102 \mathrm{~kg} \cdot \mathrm{ha}^{-1}$ obtido com a aplicação de 118,5 mm de água combinada com dose nula de potássio e um valor mínimo de $8734 \mathrm{~kg} \cdot \mathrm{ha}^{-1}$ obtido com a aplicação de 171,5 mm de água e 0,400 $\mathrm{kg}$ de $\mathrm{K}_{2} \mathrm{O}$ por planta. A produção não comercial apresentou uma tendência quadrática de redução com o aumento das doses de potássio. A produção total de frutos foi influenciada significativamente pelos tratamentos, obtendo-se um valor máximo de $14806 \mathrm{~kg} \cdot \mathrm{ha}^{-1}$ com a combinação de 118,5 mm de água com dose nula de potássio e um valor mínimo de $8879 \mathrm{~kg} \cdot \mathrm{ha}^{-1}$ obtido com a aplicação de $171,5 \mathrm{~mm}$ de água e $0,400 \mathrm{~kg}$ de $\mathrm{K}_{2} \mathrm{O}$ por planta. 


\title{
PASSION FRUIT (Passiflora edulis Sins var. flavicarpa Deg.) RESPONSE TO IRRIGATION WATER DEPTHS AND POTASSIUM LEVELS
}

\author{
Author: ARIOVALDO ANTONIO TADEU LUCAS \\ Adviser: Prof. Dr. JOSÉ ANTONIO FRIZZONE
}

\section{SUMMARY}

To study the effects of irrigation water depths and potassium levels applied by drip fertigation on the development, yield and fruit quality of yellow passion fruit (Passiflora edulis Sins var. flavicarpa Deg) a trial was carried out from May 2000 to May 2001 in the experimental area of the Department of Rural Engineering of ESALQ/USP, Piracicaba, São Paulo. Experiment was conducted in a split-plot scheme with 3 randomized blocks and 5 treatments with levels of potassium, where $\mathrm{K}_{2} \mathrm{O}$ varied from zero (control) to $0.800 \mathrm{~kg}$ per plant, applied fractionally by drip fertigation and 4 irrigation water depths, which varied from 63.3 to $220.5 \mathrm{~mm}$ and were defined as fractions of the average evapotranspiration measured in four drainage lysimeters. There was a significant effect of the water depths over stem diameter and leaf area of the yellow passion fruit. There was not effects of the treatments on the internodes length. 
Fruit weight, juice density, skin thickness and the juice yield were significantly affected by irrigation water depths, potassium levels and by the interaction between these factors. Treatments did not significantly affect the total soluble solids, $\mathrm{pH}$ and total titratable acidity of the juice. Fruit length was significantly affected by the interaction between the water depths and potassium levels and there was not significant effect of the treatments on the fruit diameter. Concentrations of potassium, magnesium and manganese in leaves were significantly influenced by the irrigation water depths and potassium levels. Boron and iron concentrations were affected only by the interaction between the water depths and potassium levels. Treatments also did not affect the nitrogen, phosphorus, calcium, sulphur, cooper and zinc concentrations in leaves. Significant effect was observed on the marketable yield, with a maximum value of $14102 \mathrm{~kg} \cdot \mathrm{ha}^{-1}$, which was obtained when $118.5 \mathrm{~mm}$ of water and zero potassium was applied. Minimum value, $8734 \mathrm{~kg} \cdot \mathrm{ha}^{-1}$, was reached when $171.5 \mathrm{~mm}$ of water and $0.400 \mathrm{~kg} \mathrm{~K}_{2} \mathrm{O}$ per plant were applied. Nonmarketable yield showed a quadratic reduction tendency with potassium levels increasing. Total yield of fruits was significantly influenced by treatments and the maximum, $14806 \mathrm{~kg} \cdot \mathrm{ha}^{-1}$, was obtained by applying $118.5 \mathrm{~mm}$ of water and zero potassium and the minimum, $8879 \mathrm{~kg} \mathrm{ha}^{-1}$, with $171.5 \mathrm{~mm}$ of water and $0.400 \mathrm{~kg} \mathrm{~K}_{2} \mathrm{O}$ per plant. 


\section{INTRODUÇÃ̃O}

A cultura do maracujá é explorada comercialmente de norte a sul do território brasileiro, envolvendo regiões tropicais e subtropicais com condições que favorecem seu bom desenvolvimento. Para uma boa produção há necessidade de uma precipitação pluviométrica alta e bem distribuída, já que a cultura produz quase que o ano todo.

No Brasil a cultura apresenta-se como uma boa alternativa aos pequenos produtores, propiciando um bom retorno econômico. O crescimento da indústria de processamento, adquirindo frutos para a produção de suco, vem contribuindo para o crescimento da cultura do maracujazeiro amarelo (Teixeira, 1989).

Em termos de trabalhos realizados com a cultura do maracujá, atualmente há um grande número que se concentra na área fitossanitária e em manejo (podas, adubações e enxertia). Porém, ainda, há muitas divergências sobre o melhor manejo da adubação da poda e da irrigação. Sabe-se que o maracujazeiro é exigente em nutrientes especialmente em nitrogênio e potássio, e também em água. Há necessidade de irrigação na cultura do maracujá nos períodos de baixa precipitação, principalmente na fase de florescimento e pegamento dos frutos.

O Brasil é o principal produtor mundial de maracujá, tendo o estado de São Paulo a maior expansão da área cultivada (Meletti, 1996; Souza \& Meletti, 1997). Os 
maiores mercados consumidores brasileiros estão nos estados de São Paulo, Rio de Janeiro, Minas Gerais, Bahia e Pernambuco.

O maracujá-amarelo é o mais conhecido, amplamente comercializado de norte a sul do país, sendo a época de maior oferta e menores preços de fevereiro a abril, quando se dá o pico da safra em todo o país. Sua utilização na forma de suco é muito apreciada, representando pelo menos 90\% do mercado (Souza \& Meletti, 1997).

Um dos problemas da cultura no país é a falta de padronização das frutas quanto ao aspecto, sabor, coloração, uniformidade de tamanho e formato (Lima, 1994; Pizzol et al., 2000).

O potássio tem papel fundamental na translocação de assimilados das folhas para as diversas partes da planta, principalmente para os frutos. Portanto, deficiência de potássio no maracujazeiro provoca atraso na floração, redução no tamanho dos frutos e na área foliar, afetando, conseqüentemente, a fotossíntese e o conteúdo de sólidos solúveis nos frutos (Manica, 1981; Kliemann et al., 1986; Baumgartner, 1987; Ruggiero et al., 1996).

Alguns autores como Ruggiero et al. (1996), Martins (1998) e Sousa (2000) relatam que o uso da irrigação no maracujazeiro promove o aumento da produtividade, permite a obtenção de produção de forma contínua e uniforme, com frutos de boa qualidade. Entretanto, ainda há necessidade de informações sobre as necessidades hídricas dessa cultura, de forma a possibilitar uma programação racional das irrigações. Como bem destacam os autores, há necessidade de pesquisas para melhor definir as tecnologias de irrigação, adubação e manejo da cultura, capazes de proporcionar o aumento da produtividade e qualidade dos frutos. 
O objetivo deste trabalho foi estudar o efeito de lâminas de irrigação e doses de potássio aplicadas via fertirrigação por gotejamento no desenvolvimento, na produtividade e na qualidade de frutos do maracujazeiro amarelo em uma cultura implantada desde maio de 1999. Este estudo visou o segundo ciclo da cultura que abrangeu o período de maio de 2000 a maio de 2001. 


\section{REVISÃO DE LITERATURA}

\subsection{Características agronômicas da cultura do maracujazeiro}

Das 400 espécies do gênero Passiflora, cerca de 50 ou 60 produzem frutos com valor comercial. Provavelmente são originários dos trópicos americanos. O gênero Passiflora possui cerca de 530 espécies tropicais e subtropicais, das quais 150 são originárias do Brasil. Entretanto poucas espécies foram introduzidas em regiões tropicais e subtropicais tornando-se base para a industria local (Martin \& Nakasone, 1970; Schultz, 1968; Medina et al., 1980). O maracujá amarelo é o mais conhecido, amplamente comercializado de norte a sul do país (Souza \& Meletti, 1997).

A planta do maracujazeiro apresenta-se como trepadeira herbácea ou lenhosa de grande porte, podendo atingir além de $10 \mathrm{~m}$ de comprimento. O caule na base é lenhoso e bastante lignificado, diminuindo o teor de lignina à medida que se aproxima o ápice da planta, podendo apresentar-se como ervas e arbustos de hastes cilíndricas ou quadrangulares, angulosa, suberificadas, glabras ou pilosas dependendo da espécie botânica, no geral apresenta-se como sendo semiflexível. A partir do caule surgem as gavinhas, folhas, gemas e brácteas (Teixeira, 1994; Silva \& São José, 1994).

O sistema radicular apresenta uma raiz central pivotante ou axial mais grossa que as demais. $\mathrm{O}$ volume da maioria das raízes finas concentra-se num raio de $0,50 \mathrm{~m}$ do 
tronco da planta e na profundidade de $0,30 \mathrm{~m}$ a $0,45 \mathrm{~m}$ de profundidade no solo (Manica, 1981; Silva \& São José, 1994; Souza \& Meletti, 1997). De acordo com Kliemann et al., (1986), o sistema radicular do maracujazeiro apresenta 3 fases de crescimento. Do plantio até os 210 dias, o crescimento é lento, com reduzida produção de matéria seca. Dos 210 aos 300 dias, há uma rápida expansão das raízes e, a partir dos 300 dias, o crescimento praticamente se estabiliza.

As folhas são simples, alternadas, comumente ovadas, elípticas, lobadas ou digitadas. Na sua base as folhas apresentam brácteas foliáceas bem desenvolvidas e gavinhas que sustentam a planta (Silva \& São José, 1994; Ruggiero et al., 1996). As flores do maracujazeiro, são hermafroditas, os estames aparecem em número de cinco, presos a um androginóforo colunar, bem desenvolvido. As anteras são grandes e mostram o grande número de grãos de pólen de coloração amarelada e pesados, o que dificulta a polinização pelo vento. A parte feminina representada por três estigmas, que variam com relação a sua curvatura, determinam a ocorrência de diferentes tipos de flores, com reflexos diferentes na polinização. As flores abrem-se uma única vez por volta das $12 \mathrm{~h}$ permanecendo assim até o início da noite, devendo ser polinizada neste período ou não haverá formação de frutos (Manica, 1981; Ruggiero et al., 1996).

O maracujazeiro amarelo é dependente da polinização cruzada realizada por agentes polinizadores para produzir frutos, devendo ser polinizada por flores de outras plantas da mesma espécie. Assim, há necessidade de polinização artificial na ausência de insetos polinizadores, cujo benefício à frutificação é inquestionável (Souza \& Meletti, 1997; Manica, 1981). 
Por ser uma planta trepadeira de crescimento vigoroso, com inúmeras brotações laterais, o maracujazeiro forma uma densa massa vegetativa, sobrecarregando o sistema de condução, dificultando a alimentação dos frutos em desenvolvimento e reduzindo a eficiência dos tratamentos fitossanitários. Para a eliminação da massa vegetativa improdutiva existente no interior da planta, pode-se realizar a poda de limpeza e renovação, contribuindo para melhorar o estado sanitário da cultura e para se obter colheita de maior quantidade e frutos de melhor qualidade. Com ela é possível renovar os ramos, promover a limpeza e aeração do pomar. A poda deve ser realizada no início da brotação na primavera, com disponibilidade de água no solo. Plantas de pomares saudáveis podem ser podadas, cortando-se os ramos da cortina produtiva cerca de $40 \mathrm{~cm}$ a $60 \mathrm{~cm}$ abaixo do arame de sustentação (Souza \& Meletti, 1997).

Os frutos do maracujazeiro são produzidos em ramos do ano, são do tipo baga com tamanho e forma variados, geralmente ovais ou subglobosos com 6-12 cm de comprimento e 4-7 cm de diâmetro. A casca do fruto é dura e tem de 3 a $10 \mathrm{~mm}$ de espessura (Martin \& Nakazone, 1970). O fruto apresenta rápido desenvolvimento nos primeiros dias após a polinização, reduzindo a seguir o crescimento até que se estabiliza, o que acontece em torno dos 18 dias, ocasião em que atingem o máximo crescimento e aos 80 dias após a polinização, inicia-se o amadurecimento dos frutos.

Por suas características de sabor e suco serem bastante apreciadas no mundo inteiro, o maracujá tem o cultivo em expansão contínua há vários anos. No período de 1990 a 1998 a produção brasileira cresceu cerca de 60\%. Em 1990, a área plantada com maracujazeiro girava em torno de 25 mil ha; em 1995, essa área chegou a 39 mil ha, 
sendo que nesse período, a área plantada na Região Sudeste aumentou 11\% (Pizzol et al., 1998; FNP CONSULTORIA \& COMÉRCIO, 2000).

Atualmente o Brasil com uma área plantada de 35637 ha, apresenta-se como o principal produtor mundial de maracujá, tendo apresentado uma evolução técnica nesta cultura ao longo dos últimos 20 anos. Dentre as regiões produtoras destacam-se a Sudeste e a Nordeste, sendo os principais estados produtores: Pará, São Paulo, Sergipe, Bahia e Ceará (FNP CONSULTORIA \& COMÉRCIO, 2002). O estado de São Paulo aparece com a maior expansão da área cultivada, por ser uma atividade bastante atrativa para pequenos produtores, uma vez que oferece um retorno econômico rápido com receitas distribuídas quase o ano inteiro (Meletti, 1996 e Souza \& Meletti, 1997).

A colheita do maracujá, no Estado de São Paulo, estende-se de meados de novembro até agosto. Conforme a região esse período é menor, considerando-se as diferenças climáticas regionais. A colheita é efetuada duas vezes por semana, recolhendo os frutos do chão. A ausência de calor, umidade e dias longos determinam a entressafra, tanto maior quanto mais ameno o clima (Souza \& Meletti, 1997).

A safra da Região Sudeste pode ser destinada para o mercado interno de frutas frescas ou para a indústria de sucos e polpas congeladas. Basicamente a produção brasileira de maracujá destina $50 \%$ para o mercado de frutas frescas e $50 \%$ para a indústria de sucos (Pizzol et al., 1998).

As maiores limitações da cultura do maracujazeiro são climáticas (Martin \& Nakasone, 1970), sendo responsáveis por grandes variações no ciclo produtivo do maracujá em diferentes localidades e épocas do ano (Veras, 1997). 
Considerada uma espécie tropical, o maracujá pode apresentar boa produtividade mesmo em temperaturas relativamente baixas em níveis de altitude de até $3200 \mathrm{~m}$ ou em áreas tropicais de até $35^{\circ}$ de latitude nas áreas subtropicais (Menzel \& Simpson, 1989 e Menzel \& Simpson, 1994).

Em relação aos efeitos dos fatores climáticos Menzel et al. (1987), relatam que durante o inverno possivelmente o fotoperíodo curto, o déficit hídrico e a baixa temperatura do ar são fatores responsáveis pelo baixo crescimento vegetativo e pela baixa produtividade do maracujá. Matsumoto \& São José (1991) estudando fatores que afetam a frutificação do maracujazeiro ácido observaram, que nos meses mais frios ocorreu à presença de botões florais em maracujazeiros, no entanto os mesmos desenvolveram-se, mas não produziram frutos, afirmando os autores que a baixa qualidade da fecundação observada, dentre outros fatores, ocorreu devido às baixas temperaturas em conjunto com ventos frios. Por outro lado, temperaturas mais elevadas podem provocar a queda de frutos pela inibição da fertilidade do óvulo, ou mais tarde, por ocasião do desenvolvimento da semente, resultando em um menor número de sementes por fruto.

Veras (1997) estudando a fenologia, produção e caracterização físico-química dos maracujazeiros ácido e doce para as condições de cerrado, verificou que apesar do desenvolvimento vegetativo vigoroso, temperaturas superiores a $33^{\circ} \mathrm{C}$ levam à formação de frutos pequenos afetando negativamente seu crescimento, peso do fruto e rendimento em termos de peso do suco. O peso do fruto foi significativamente maior com temperaturas variando entre $13^{\circ}$ e $28^{\circ} \mathrm{C}$ do que a $33^{\circ} \mathrm{C}$ com pequena diferença entre $23^{\circ}$ e $28^{\circ} \mathrm{C}$. O peso da casca foi maior sob baixas temperaturas, enquanto o peso do suco foi 
maior com temperatura de $28^{\circ} \mathrm{C}$. O efeito no florescimento é intensificado em períodos de temperaturas moderadamente altas, devido à interação entre temperatura e radiação (Menzel et al., 1987).

Gurnah \& Gachanja (1984), confirmaram o marcante papel da temperatura na flutuação sazonal da produção mesmo em plantios irrigados e Müller (1977) considerou a variação da temperatura mais importante que a fertilização na qualidade do fruto.

Menzel \& Simpson (1989), em experimento desenvolvido em casa de vegetação com 5 regimes de radiação obtidos com tela de sombreamento, verificaram que todos os tratamentos causaram aumento significativo no crescimento do ramo principal quando comparado com a testemunha. Não observaram efeito no número de internós. Os maiores níveis de sombreamento reduziram a área foliar total e o número de flores abertas diminuiu com a redução da radiação. Verificaram também que o desenvolvimento e o crescimento de diferentes órgãos variaram sensivelmente para pequenas mudanças na radiação, fase vegetativa (crescimento de raiz e área foliar) e produtiva (abertura de flores).

As informações na literatura sobre nutrição mineral do maracujazeiro são muito restritas, principalmente com relação às exigências em potássio, época e modo de aplicação, marcha de absorção, sintomatologia das deficiências, diagnose foliar e respostas à aplicação de macro e micronutrientes (Medina et al., 1980). Todavia, autores como Haag et al. (1973), Menzel et al. (1987), Menzel \& Simpson (1988) e Baumgartner et al. (1978) apresentaram alguns resultados referentes à nutrição, acumulação de nutrientes nos órgãos da planta e sua translocação para os frutos. 
O nitrogênio e o potássio são os macronutrientes exigidos em maior proporção pelo maracujazeiro, seguido por cálcio, enxofre, fósforo e magnésio (Haag et al. 1973). Para os autores, as quantidades absorvidas desses elementos são pequenas até os 190 dias de idade. A partir daí, a absorção de nitrogênio, potássio e cálcio são crescentes e, para os demais elementos, o aumento só se verifica a partir dos 250 dias. Já Aguirre (1977) observou que a planta mostra-se mais exigente em nitrogênio e potássio, relativamente exigente em cálcio e menos exigente em fósforo, magnésio e enxofre, até 262 dias de idade e, com relação aos micronutrientes, o ferro é o mais exigido, seguido do boro, manganês, zinco, cobre e molibdênio. Kliemann et al. (1986) afirmam que a absorção de nutrientes pela planta de maracujazeiro intensifica-se a partir de 210 dias de idade, que corresponde ao estádio de pré-frutificação.

Fatores climáticos afetam a absorção e acumulação de nutrientes pelo maracujazeiro. A máxima acumulação de nutrientes na parte aérea das plantas ocorre com temperaturas diurna e noturna de $25^{\circ}$ e $20^{\circ} \mathrm{C}$, respectivamente. Os níveis de potássio na planta aumentam com a temperatura enquanto que o nitrogênio, enxofre e magnésio tem seus níveis reduzidos (Menzel et al., 1987).

Müller et al. (1979) avaliando os efeitos de doses de nitrogênio e de potássio no maracujazeiro em diferentes épocas, observou que na ausência de adubação nitrogenada a aplicação de potássio proporcionou maior peso médio de frutos e induziu a antecipação na maturação dos mesmos. Já com doses elevadas de nitrogênio houve tendência de encerramento mais tardio da colheita, enquanto que Aguirre (1977), relata que a deficiência de nitrogênio na solução nutritiva acarretou uma diminuição no desenvolvimento da raiz, do caule e da planta toda, evidenciando o efeito do elemento 
no crescimento vegetativo das plantas. A omissão de nitrogênio na solução nutritiva causou um aumento no teor de boro do caule, quando comparado com solução completa, sem deficiência de qualquer nutriente, que possivelmente seja devido a uma concentração desse elemento pela redução do crescimento da planta.

De acordo com Baumgartner (1987) e Primavesi \& Malavolta (1980) o maracujazeiro amarelo apresenta as seguintes exigências nutricionais até os 262 dias após plantio: $\mathrm{N}>\mathrm{K}>\mathrm{Ca}>\mathrm{S}>\mathrm{Mg}>\mathrm{P}>\mathrm{B}>\mathrm{Mn}>\mathrm{Zn}>\mathrm{Cu}>\mathrm{Mo}$, sendo que somente as deficiências de $\mathrm{N}, \mathrm{S}, \mathrm{Ca}$ e $\mathrm{Cu}$ mostraram um efeito acentuado no desenvolvimento das plantas de maracujá. Contudo, é importante salientar que o maior aumento na absorção de $\mathrm{N}, \mathrm{P}$ e Ca ocorre no período da pré-frutificação, sendo que o acúmulo de nitrogênio e de potássio é mais intenso nos frutos, estabilizando-se no amadurecimento (Kliemann et al., 1986).

Com relação às interações entre os nutrientes, vários trabalhos desenvolvidos com diversas plantas, mostram claramente estas ocorrências. O teor de um dado nutriente na planta pode ser influenciado pela presença de outro e três casos principais de interações podem ocorrer de acordo com Malavolta (1980): 1) antagonismo: quando a presença de um nutriente no meio, diminui a absorção do outro, isto é comum entre o $\mathrm{Ca}$ e $\mathrm{Cu}$; 2) inibição: trata-se da diminuição, na quantidade de um nutriente absorvido devido à presença do outro, pode ser tanto competitiva, caso entre o $\mathrm{K}$ e o $\mathrm{Ca}$, como não competitiva, como ocorre entre o $\mathrm{P}$ e o $\mathrm{Zn}$; 3) sinergismo: refere-se a um aumento da absorção de um nutriente, devido à presença de outro, caso entre o K e o Ca quando o Ca se encontra em baixas concentrações. 
O potássio participa em diversas fases do metabolismo, como na reação de fosforilação, síntese de carboidratos e proteínas, respiração e regulação da abertura e fechamento de estômatos. Ele é importante no desenvolvimento das raízes e essencial na frutificação e maturação dos frutos, pois é responsável pela conversão do amido em açucares (Ferri 1979). Pode funcionar como ativador de enzimas, cerca de 46 enzimas exigem K para sua atividade (Malavolta et al., 1974).

O potássio se apresenta sob as formas trocável e não trocável, sendo absorvido sob a forma de $\mathrm{K}^{+}$. Sua redistribuição pelo floema é muito boa, uma vez que está presente no vegetal em grande quantidade. Quando se encontra em fase de carência é translocado dos órgãos mais novos.

A maior parte do potássio de que a planta necessita, chega às raízes através de mecanismos de fluxo de massa e difusão. Vários fatores podem afetar absorção de potássio pelas plantas, tais como: concentração de $\mathrm{K}^{+}$na solução do solo, temperatura e umidade do solo, espécie e cultivares, idade da planta, morfologia radicular e transpiração (Babear, 1982).

Segundo Rodriguez (1982), as ações do potássio e do nitrogênio se complementam nas plantas, devendo manter um certo equilíbrio. $\mathrm{O}$ excesso de potássio interfere negativamente na absorção de $\mathrm{Ca}, \mathrm{Mg}, \mathrm{P}, \mathrm{S}$ e $\mathrm{Cl}$. Sua falta induz um maior acúmulo de N, Mg, Ca e B na planta.

De acordo com Aguirre (1977), as partes da planta de maracujá amarelo que melhor refletem o seu estado nutricional, para cada elemento, são: $\mathrm{N}$ - folhas da haste madura; $\mathrm{P}$ - folhas da haste madura; $\mathrm{K}$ - folhas do caule e gavinha; $\mathrm{Ca}$ - folhas da haste nova; $\mathrm{Mg}$ - folhas da haste madura; $\mathrm{S}$ - folhas da haste madura; $\mathrm{B}$ - folhas da haste 
nova; $\mathrm{Cu}$ - folhas da haste madura e gavinhas; Fe - gavinhas; $\mathrm{Mn}$ - folhas da haste madura; Mo - folhas da haste nova e $\mathrm{Zn}$ - gavinhas.

Os resultados de pesquisas para adubação de produção e recomendações de adubação para o maracujazeiro são divergentes. Meletti (1996); Souza \& Meletti (1997) recomendam a adubação de acordo com a produtividade esperada e deve-se obedecer ao parcelamento. Já Rizzi et al. (1998) consideram as condições em que a cultura está sendo conduzida, recomendando a adubação através da interpretação dos resultados da análise de solo ou por produtividade esperada. Baumgartner (1987) recomenda aplicar por planta $295 \mathrm{~g}$ de $\mathrm{N}, 293 \mathrm{~g}$ de $\mathrm{K}_{2} \mathrm{O}, 60 \mathrm{~g}$ de $\mathrm{P}_{2} \mathrm{O}_{5}$ e 15 a $30 \mathrm{~g}$ de boro sem considerar a capacidade do solo em fornecer o nutriente na produção de primeiro ano do maracujazeiro.

Em pesquisa realizada com doses de nitrogênio e potássio no maracujazeiro, Martins (1998) verificou efeito linear de diferentes doses de potássio sobre sólidos solúveis e rendimento de suco, obtendo-se a maior produtividade com a aplicação de $429 \mathrm{~g}$ de $\mathrm{K}_{2} \mathrm{O}$ por planta.

\subsection{Irrigação e fertirrigação}

A irrigação tem sido reconhecida como parte fundamental do manejo da cultura do maracujazeiro, não só como condição essencial, principalmente em regiões subúmidas e semi-áridas, mas também como alternativa de produção na entressafra em regiões onde a precipitação é considerada razoável, como é o caso da região sudeste, onde no período de setembro a dezembro, quando os preços atingem valores mais 
elevados, ocorre um período de déficit hídrico no solo, que antecede a estação chuvosa. Nesse caso, a irrigação permite ao produtor antecipar a produção colocando frutos no mercado ainda no período de entressafra (Coelho, 1999).

Autores como Manica, (1981) e Ruggiero et al. (1996), relatam que a irrigação é indispensável para o maracujazeiro, pois aumenta a produtividade, permite a obtenção de produção de forma contínua e uniforme, com frutos de boa qualidade. A falta de água no solo provoca a queda das folhas e dos frutos, principalmente no início de seu desenvolvimento e, quando se forma, podem crescer com enrugamento, prejudicando a qualidade da produção.

Neto et al. (1983) no vale do Rio Moxotó em Pernambuco, observaram que além da maior produtividade alcançada, o período frutífero atinge de 9 a 10 meses, permitindo a oferta de frutas durante quase todo o ano, concordando com outros autores como Manica (1981) e Ruggiero (1987) que também afirmam que a irrigação aumenta o período produtivo e a produção de frutos do maracujazeiro. Coelho e Cordeiro (1979) estudaram diferentes freqüências de irrigação na cultura do maracujazeiro, irrigado por sulcos (freqüência de 5, 9 e 13 dias) e por gotejamento (freqüências de 2 e 5 dias). Concluíram que não houve diferença significativa na produção de frutos entre os tratamentos.

Sousa (2000) pesquisando os efeitos de níveis de irrigação e doses de potássio na cultura do maracujazeiro, observou que a aplicação de $75 \%$ da evapotranspiração medida em lisímetro de drenagem combinado com uma dose de $0,675 \mathrm{~kg}$ de $\mathrm{K}_{2} \mathrm{O}$ por planta, favoreceu maior produtividade comercial. 
Vasconcelos (1994) destaca que o maracujazeiro responde bem a irrigação e que o teor de água no solo é um dos fatores que mais afeta o florescimento da cultura. Menzel et al. (1986b) submetendo o maracujazeiro, durante o crescimento em estufa, a quatro níveis de estresse hídrico, irrigando-os quando o potencial da água no solo atingia 0,$0025 ; 0,01 ; 0,14$ e 1,5MPa, verificaram que a produção de matéria seca é afetada antes dos sintomas visíveis de déficit de água na planta se manifestarem, limitando acentuadamente o crescimento vegetativo e a produção, concluindo que a irrigação em pomares de maracujá deveria manter a umidade do solo próximo à capacidade de campo durante a floração.

O efeito da umidade do solo para o maracujazeiro relaciona-se com a absorção de nutrientes. O estresse hídrico reduz o acúmulo de nutrientes na parte aérea (Malavolta, 1994). Como efeito da redução do teor de água no solo, o maracujazeiro produz ramos menores, com menor número de nós e comprimento de internós, refletindo conseqüentemente no número de botões florais e flores abertas (Menzel et al., 1986a).

O método de irrigação mais utilizado para o maracujazeiro é o gotejamento, pois proporciona a aplicação de água e nutrientes próximos ao tronco da planta, onde há maior concentração das raízes, permitindo melhor controle da umidade, como também não molha a parte aérea das plantas, reduzindo a incidência de doenças (Ruggiero et al. 1996).

Segundo Coelho (1999) o sistema de irrigação por gotejamento tem sido bem aceito entre os produtores, sendo que seu uso adequado proporciona condições de umidade e aeração do solo que favorecem o desenvolvimento e produção da cultura. É um sistema que não proporciona microclima úmido transitório durante o ciclo de 
irrigação, dada sua característica de aplicar água diretamente no solo. Os gotejadores, em número de um a dois por planta, devem ser instalados distantes da fileira de plantas de 0,2 $\mathrm{m}$ (solos arenosos) a 0,4 m (solos argilosos).

Olitta (1984) em estudos sobre irrigação por gotejamento, verificou que esse sistema permite um bom controle da irrigação e economia de água em várias culturas e, em algumas condições, tem propiciado produções superiores aos obtidos com o uso de outros métodos. A irrigação por gotejamento oferece um grande potencial de benefícios no uso eficiente da água, resposta das plantas e manejo da irrigação. Algumas dessas vantagens não são exclusivas desse sistema de irrigação, pois com outros também é possível alcançar resultados semelhantes.

Contudo, independente do método ou sistema de irrigação utilizado, cuidados devem ser tomados para não permitir que as plantas sejam submetidas a estresse hídrico e nem a excesso de umidade. A umidade do solo deve ser mantida próximo da capacidade de campo (Ruggiero et al. 1996).

Para cada situação de solo deve-se observar os teores de água: para solos arenosos os teores de água devem corresponder a valores de potencial matricial próximos de $6 \mathrm{kPa}$, e superior a $20 \mathrm{kPa}$ para solo de textura média a argilosa. Stavely \& Wolstenholme (1990) concluíram que o potencial mátrico do solo para a cultura do maracujá não deve ser inferior a 20kPa durante aos períodos críticos de diferenciação de flores e pegamento de frutos.

Embora a literatura evidencie que o maracujá responde bem a irrigação, Ruggiero et al. (1996) destacam que a irrigação no maracujazeiro ainda é pouco pesquisada, todavia, vários autores concordam que seu uso pode prolongar o período de 
produção, aumentar a produtividade e melhorar a qualidade dos frutos. Por essas razões, há necessidade de pesquisas nessa área visando determinar o manejo adequado de irrigação para a cultura, envolvendo principalmente necessidades hídricas, tensão ótima de umidade no solo, valores ótimos de lâminas e freqüências de irrigação.

A fertirrigação no Brasil vem sendo utilizada na fruticultura, principalmente nas Regiões Nordeste e Sudeste, com as culturas de citros, manga, mamão, banana, coco, caju, maracujá, uva, abacaxi e acerola (Carrijo et al., 1999).

Segundo Vivancos (1993) entende-se por fertirrigação a aplicação dos fertilizantes que necessitam os cultivos, junto com a água de irrigação, aproveitando-se os sistemas de irrigação como meio para distribuição dos elementos nutritivos. Para isso, utiliza-se a água como veículo, com os elementos dissolvidos na mesma. Com essa prática o que se faz é irrigar com uma solução nutritiva, de forma continua ou intermitente. Naturalmente, nem todos os tipos de irrigação permitem realizar a fertirrigação, já que a exigência principal é obter a máxima uniformidade na aplicação. Desse feito, a fertirrigação se associa basicamente com a irrigação localizada de alta freqüência, como o gotejamento e a microaspersão, sem prejuízo de sua possível aplicação em outros sistemas, como a aspersão.

De acordo com Coelho (1999) fertirrigação é a aplicação de fertilizantes via água de irrigação, consistindo no uso racional dos fertilizantes em agricultura irrigada, uma vez que aumenta a eficiência dos mesmos, reduz a mão-de-obra e o custo do sistema de irrigação. Além disso, permite flexibilizar a época de aplicação dos nutrientes, que pode ser fracionada conforme a necessidade da cultura nas suas diversas fases de desenvolvimento resultando em máxima eficiência na fertilização, uma vez que a 
aplicação dos adubos é feita diretamente na zona de maior concentração de raízes, onde conseqüentemente o sistema radicular é mais ativo.

Papadopoulos (1999) relata que na fertirrigação os fertilizantes solúveis nas concentrações exigidas pelas culturas são transmitidos através da água de irrigação para o volume molhado do solo. Nesse sentido Coelho (1999) informa que a aplicação de fertilizantes via água de irrigação deve obedecer a alguns critérios: os fertilizantes devem possuir alta solubilidade em água; os fertilizantes devem ser compatíveis com os sais existentes na água de irrigação e não devem haver reações químicas entre fertilizantes nas misturas, de modo a formar precipitados na solução. 


\section{MATERIAL E MÉTODOS}

\subsection{A área de estudos}

O experimento foi realizado na Fazenda Areão, pertencente à Escola Superior de Agricultura "Luiz de Queiroz", localizada no município de Piracicaba, estado de São Paulo, com latitude $22^{\circ} 42^{\prime} 30^{\prime \prime} \mathrm{S}$, longitude $47^{\circ} 38^{\prime} 00^{\prime}$ "e altitude $576 \mathrm{~m}$, cujo solo é classificado como Terra Roxa Estruturada.

O clima, segundo a classificação de Köeppen, é do tipo Cwa, ou seja, subtropical úmido com estiagem no inverno, precipitação pluviométrica média de $1247 \mathrm{~mm}$, temperatura média de $21,1^{\circ} \mathrm{C}$, umidade relativa média de $74 \%$ e velocidade média do vento de $2,2 \mathrm{~m} \mathrm{~s}^{-1}$.

O experimento com a cultura do maracujá amarelo foi conduzido de maio de 2000 a maio de 2001, correspondendo ao segundo ciclo de desenvolvimento da cultura, ou seja: dos 430 aos 670 dias após o transplantio das mudas. A área experimental foi implantada em 1999 por Sousa (2000), que realizou o plantio das mudas e instalação do sistema de irrigação por gotejamento.

A caracterização física e química do solo, na época de implantação, foi realizada com amostras de solo retiradas nas camadas de 0,00-0,20 m, 0,20-0,40 m e 0,40-0,60 m. 
Foram realizadas análises de $\mathrm{pH}$, matéria orgânica, macro e micronutrientes, soma de bases, capacidade de troca de cátions e saturação por bases (Tabelas 1 e 2), densidade global, teores de argila, silte e areia (Tabela 3) e curva de retenção de água no solo (Figura 1).

Tabela 1. Resultados de análises químicas do solo da área experimental: pH, matéria orgânica (M.O), macronutrientes, soma de base (SB), capacidade de troca de cátions $(\mathrm{T})$ e saturação por bases $(\mathrm{V})$.

\begin{tabular}{|c|c|c|c|c|c|c|c|c|c|c|c|c|}
\hline $\begin{array}{c}\text { Camada } \\
\text { M }\end{array}$ & $\begin{array}{r}\mathrm{pH} \\
\mathrm{CaCl}_{2}\end{array}$ & $\begin{array}{c}\text { M.O } \\
\text { g.dm }\end{array}$ & $\begin{array}{l}\mathrm{P} \\
\mathrm{m}\end{array}$ & $\begin{array}{l}{\mathrm{S}-\mathrm{SO}_{4}} \\
\mathrm{dcm}^{-3}\end{array}$ & $\mathrm{~K}$ & $\mathrm{Ca}$ & & $\mathrm{Al}$ & $\begin{array}{l}\mathrm{H}+\mathrm{Al} \\
\mathrm{dm}^{-3}\end{array}$ & SB & $\mathrm{T}$ & $\begin{array}{l}\mathrm{V} \\
\%\end{array}$ \\
\hline $0,00-0,20$ & 5,2 & 14 , & 4 & 54 & 1,5 & 33 & 13 & 0 & 28 & 47,5 & 75,5 & 63 \\
\hline $0,20-0,40$ & 5,0 & 17 & 4 & 52 & 1,6 & 28 & 12 & 0 & 31 & 41,6 & 72,6 & 57 \\
\hline $0,40-0,60$ & 5,3 & 9 & 9 & 44 & 0,5 & 32 & 6 & 0 & 22 & 38,5 & 60,5 & 64 \\
\hline
\end{tabular}

Tabela 2. Resultados de análises químicas de micronutrientes do solo da área experimental: Boro $(\mathrm{B})$, cobre $(\mathrm{Cu})$, ferro $(\mathrm{Fe})$ manganês $(\mathrm{Mn})$ e zinco $(\mathrm{Zn})$.

\begin{tabular}{cccccc}
\hline $\begin{array}{c}\text { Camada } \\
\mathrm{m}\end{array}$ & $\mathrm{B}$ & $\mathrm{Cu}$ & $\begin{array}{c}\mathrm{Fe} \\
\mathrm{mg} . \mathrm{dm}^{-3}\end{array}$ & $\mathrm{Mn}$ & $\mathrm{Zn}$ \\
\hline $0,00-0,20$ & 0,09 & 2,70 & 13,60 & 27,40 & 0,70 \\
$0,20-0,40$ & 0,22 & 3,40 & 17,60 & 44,00 & 0,80 \\
$0,40-0,60$ & 0,10 & 0,90 & 5,20 & 4,60 & 0,20 \\
\hline
\end{tabular}


Tabela 3. Valores de densidade global, teores de argila, silte e areia de amostras de solo da área experimental.

\begin{tabular}{ccccccc}
\hline $\begin{array}{c}\text { Camada } \\
\mathrm{m}\end{array}$ & \multicolumn{2}{c}{$\begin{array}{c}\text { PC } \\
\mathrm{cm}^{3} \mathrm{~cm}^{-3}\end{array}$} & $\begin{array}{c}\text { Densidade } \\
\mathrm{kg} \mathrm{dm}^{-3}\end{array}$ & Argila & $\begin{array}{c}\text { Silte } \\
\mathrm{g} \mathrm{kg}^{-1}\end{array}$ & Areia \\
\hline $0,00-0,20$ & 0,4148 & 0,3472 & 1,49 & 624,0 & 172,0 & 204,0 \\
$0,20-0,40$ & 0,4193 & 0,3491 & 1,46 & 694,3 & 138,3 & 167,4 \\
$0,40-0,60$ & 0,4500 & 0,3808 & 1,43 & 688,9 & 136,3 & 174,8 \\
\hline
\end{tabular}
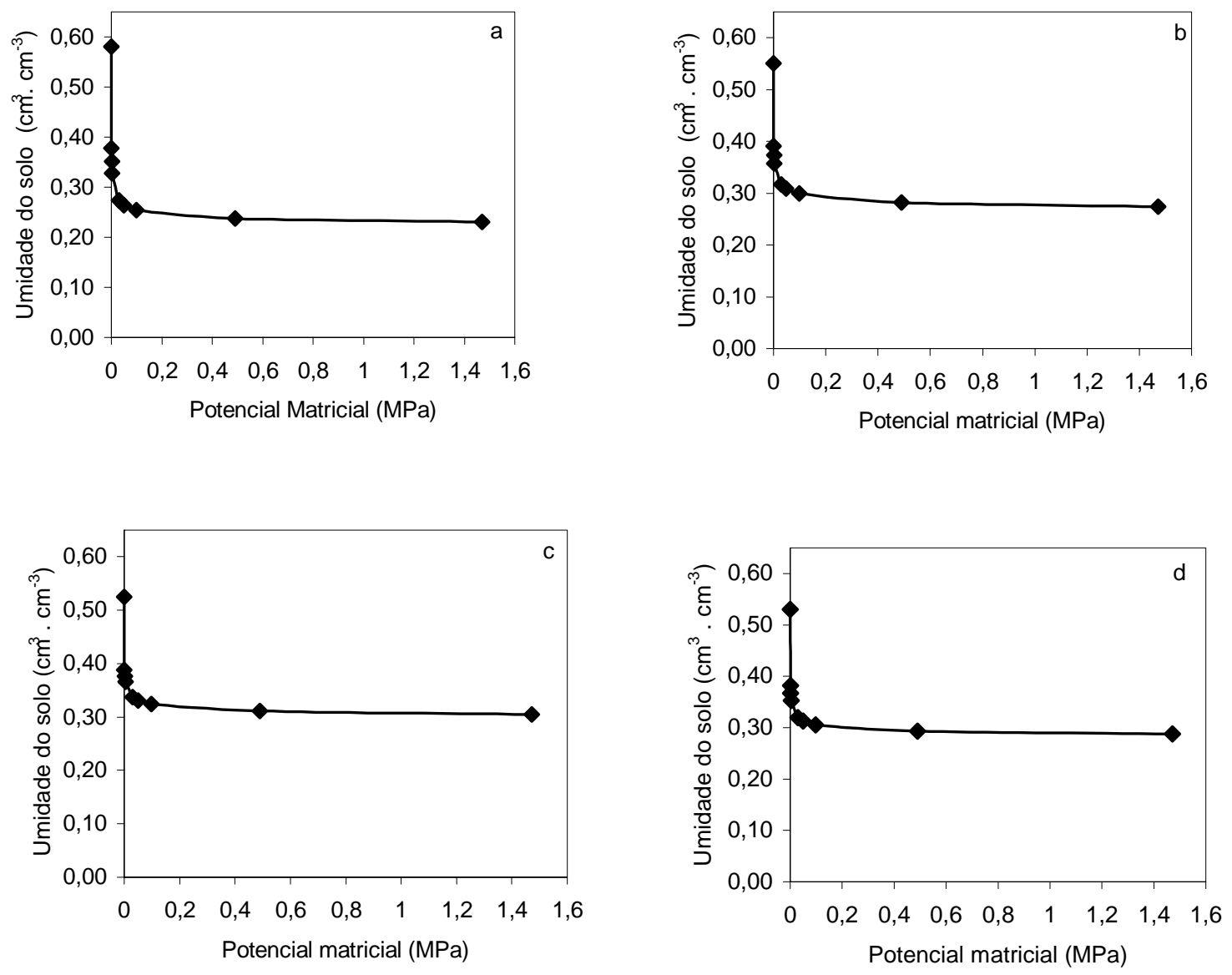

Figura 1 - Curvas de retenção de água no solo da área experimental para camada (a) 0,0 - 0,10m; (b) $0,10-0,30 \mathrm{~m}$; (c) $0,30-0,50 \mathrm{~m}$ e (d) $0,50-0,70 \mathrm{~m}$. 
A água para irrigação foi proveniente de uma barragem próxima da área experimental. O conjunto moto-bomba recalcava água da barragem até o cabeçal de controle situado na área. As características químicas da água utilizada para a irrigação encontram-se na Tabela 4. As amostras de água foram coletadas após o sistema de filtragem, em três períodos: março, maio e outubro de 2000.

Tabela 4. Resultados das análises químicas de água da barragem localizada na Fazenda Areão, utilizada para a irrigação.

\begin{tabular}{|c|c|c|c|c|}
\hline \multirow[t]{2}{*}{ Parâmetros } & \multirow[t]{2}{*}{ Unidade } & \multicolumn{2}{|c|}{ Resultados } & \multirow[b]{2}{*}{ Outubro } \\
\hline & & Março & Maio & \\
\hline Alcalinidade $\left(\mathrm{CO}_{3}{ }^{2-}+\mathrm{HCO}_{3}\right)$ & $\mathrm{mg} \mathrm{L}^{-1}$ & 21,0 & 13,8 & 40,8 \\
\hline Cloreto $\left(\mathrm{Cl}^{-}\right)$ & $\mathrm{mg} \mathrm{L}^{-1}$ & 3,5 & 5,8 & 20,2 \\
\hline Nitrato $\left(\mathrm{N}-\mathrm{NO}_{3}\right)$ & $\mathrm{mg} \mathrm{L}^{-1}$ & 1,4 & 1,2 & 0,4 \\
\hline Sulfato $\left(\mathrm{SO}_{4}{ }^{2-}\right)$ & $\mathrm{mg} \mathrm{L}^{-1}$ & 9,5 & 10,4 & 31,4 \\
\hline Fósforo $(\mathrm{P})$ & $\mathrm{mg} \mathrm{L}^{-1}$ & 0,05 & 0,14 & 0,10 \\
\hline Nitrogênio Amoniacal $\left(\mathrm{N}-\mathrm{NH}_{3}\right)$ & $\mathrm{mg} \mathrm{L}^{-1}$ & 0,3 & 0,2 & 0,1 \\
\hline Sódio $\left(\mathrm{Na}^{+}\right)$ & $\mathrm{mg} \mathrm{L}^{-1}$ & 2,3 & 0,9 & 31,5 \\
\hline Potássio $\left(\mathrm{K}^{+}\right)$ & $\mathrm{mg} \mathrm{L}^{-1}$ & 3,0 & 2,3 & 5,0 \\
\hline Cálcio $\left(\mathrm{Ca}^{2+}\right)$ & $\mathrm{mg} \mathrm{L}^{-1}$ & 4,6 & 4,0 & 7,1 \\
\hline Magnésio $\left(\mathrm{Mg}^{2+}\right)$ & $\mathrm{mg} \mathrm{L}^{-1}$ & 1,9 & 1,8 & 2,0 \\
\hline Ferro $(\mathrm{Fe})$ & $\mathrm{mg} \mathrm{L}^{-1}$ & 0,03 & 0,24 & 0,28 \\
\hline Cobre $(\mathrm{Cu})$ & $\mathrm{mg} \mathrm{L}^{-1}$ & 0,01 & 0,04 & 0,01 \\
\hline Manganês (Mn) & $\mathrm{mg} \mathrm{L}^{-1}$ & 0,01 & 0,02 & 0,01 \\
\hline Zinco & $\mathrm{mg} \mathrm{L}^{-1}$ & 0,07 & 0,02 & 0,01 \\
\hline Condutividade elétrica & $\mathrm{mS} \mathrm{cm} \mathrm{cm}^{-1}$ & 0,10 & 0,10 & 0,18 \\
\hline $\mathrm{PH}$ & & 7,6 & 7,3 & 7,3 \\
\hline Acidez & $\mathrm{mg} \mathrm{L}^{-1}$ & 2,5 & 1,5 & 3,0 \\
\hline Gás Carbônico $\left(\mathrm{CO}_{2}\right)$ & $\mathrm{mg} \mathrm{L}^{-1}$ & 1,0 & 1,0 & 3,5 \\
\hline Sedimentos & $\mathrm{mg} \mathrm{L}^{-1}$ & 21,3 & 15,0 & 57,0 \\
\hline
\end{tabular}

Os dados meteorológicos apresentados na Tabela 5 foram obtidos na estação meteorológica do Departamento de Ciências Exatas da ESALQ/USP, abrangendo o período de maio de 2000 a abril de 2001, fase de desenvolvimento da pesquisa. 
Tabela 5. Valores médios mensais de radiação solar global (RG), número de horas de insolação, precipitação pluviométrica (P), umidade relativa do ar (UR), velocidade média do vento a $2 \mathrm{~m}$ de altura $\left(\mathrm{U}_{2}\right)$ e temperatura média do ar $(\mathrm{T})$ no período de maio de 2000 a abril de 2001.

\begin{tabular}{ccccccc}
\hline Meses & $\begin{array}{c}\mathrm{RG} \\
\mathrm{cal} \mathrm{cm} \mathrm{d}^{-1}\end{array}$ & $\begin{array}{c}\text { Insolação- } \\
\mathrm{h} \mathrm{d}^{-1}\end{array}$ & $\begin{array}{c}\mathrm{P} \\
\mathrm{mm}\end{array}$ & $\begin{array}{c}\mathrm{UR} \\
\%\end{array}$ & $\begin{array}{c}\mathrm{U}_{2} \\
\mathrm{~m} \mathrm{~s}^{-1}\end{array}$ & $\begin{array}{c}\mathrm{T} \\
{ }^{\circ} \mathrm{C}\end{array}$ \\
\hline Maio & 347 & 7,4 & 5,3 & 74 & 1,94 & 18,9 \\
Junho & 304 & 6,7 & 5,2 & 71 & 1,88 & 19,3 \\
Julho & 320 & 6,5 & 60,4 & 72 & 2,00 & 16,8 \\
Agosto & 324 & 5,7 & 84,4 & 68 & 2,33 & 19,5 \\
Setembro & 396 & 6,2 & 91,2 & 73 & 2,52 & 21,2 \\
Outubro & 480 & 7,2 & 114,2 & 69 & 2,19 & 25,0 \\
Novembro & 465 & 6,8 & 239,2 & 77 & 2,11 & 23,8 \\
Dezembro & 448 & 5,6 & 174,5 & 81 & 1,91 & 24,4 \\
Janeiro & 509 & 7,4 & 229,96 & 75 & 1,91 & 25,8 \\
Fevereiro & 457 & 6,2 & 92,7 & 82 & 1,58 & 26,0 \\
Março & 450 & 7,0 & 164,2 & 77 & 1,66 & 25,4 \\
Abril & 420 & 8,2 & 24,1 & 73 & 1,75 & 23,9
\end{tabular}

\subsection{Delineamento experimental}

O delineamento experimental empregado foi o de blocos ao acaso com parcelas subdivididas. Foram utilizados 3 blocos com 5 tratamentos de adubação potássica (K) aplicados às parcelas e 4 tratamentos de irrigação (W) aplicados às subparcelas.

Os tratamentos de adubação potássica foram: $\mathrm{K}_{0}-$ sem adição de $\mathrm{K}_{2} \mathrm{O}$ (testemunha); $\mathrm{K}_{1}$ - adição de $0,200 \mathrm{~kg}$ de $\mathrm{K}_{2} \mathrm{O}$ por planta; $\mathrm{K}_{2}$ - adição de $0,400 \mathrm{~kg}$ de 
$\mathrm{K}_{2} \mathrm{O}$ por planta; $\mathrm{K}_{3}$ - adição de $0,600 \mathrm{~kg}$ de $\mathrm{K}_{2} \mathrm{O}$ por planta e $\mathrm{K}_{4}$ - adição de $0,800 \mathrm{~kg}$ de $\mathrm{K}_{2} \mathrm{O}$ por planta.

As doses de $\mathrm{K}_{2} \mathrm{O}$ foram aplicadas parceladamente, com intervalos de sete dias entre aplicações, durante a segunda fase de produção da cultura (dos 430 dias aos 670 dias após o transplantio). O fertilizante utilizado foi o nitrato de potássio $\left(\mathrm{KNO}_{3}\right)$, em quantidades proporcionalizadas segundo a curva de acúmulo de nutriente apresentada na Tabela 6 (adaptada de Haag et al.,1973), perfazendo 32 aplicações.

Tabela 6. Valores percentuais de acúmulo de nitrogênio $(\mathrm{N})$ e potássio $\left(\mathrm{K}_{2} \mathrm{O}\right)$ pelo maracujazeiro na fase de produção.

\begin{tabular}{ccc}
\hline Períodos & $\mathrm{N}$ & $\mathrm{K}_{2} \mathrm{O}$ \\
& $\%$ & $\%$ \\
\hline $430-460$ & 5 & 4,5 \\
$460-490$ & 5,7 & 4,8 \\
$490-520$ & 6,0 & 5,7 \\
$520-550$ & 7,3 & 6,3 \\
$550-580$ & 10,0 & 10,2 \\
$580-610$ & 17,0 & 17,5 \\
$610-640$ & 22,0 & 23,0 \\
$640-670$ & 37,0 & 28,0 \\
\hline
\end{tabular}

Adaptado de Haag et al. (1973).

Os tratamentos de irrigação, aplicados nas subparcelas, constaram da aplicação de 4 lâminas de água (W), definidas em função da lâmina média evapotranspirada (ET), 
medida em 4 lisímetros de drenagem contendo plantas de maracujazeiro, localizados no centro da área experimental: $\mathrm{W}_{1}: 0,29 \mathrm{ET} ; \mathrm{W}_{2}$ : 0,54 ET; $\mathrm{W}_{3}: 0,78 \mathrm{ET}_{\text {e }} \mathrm{W}_{4}:$ 1,00 ET.

A Tabela 7 apresenta o esquema da análise de variância utilizado. O valor de $\mathrm{F}$ testou a hipótese $\mathrm{H}_{0}$, ou seja, de que não existe diferença significativa entre as médias dos tratamentos. O nível mínimo de significância considerado para a rejeição dessa hipótese foi $5 \%$, ou seja, sempre que o valor da probabilidade do teste $\mathrm{F}$ for menor ou igual a 0,05 $(\alpha \leq 0,05)$ aceitou-se que há diferença entre pelo menos duas médias de tratamento e procedeu-se então o detalhamento da análise.

Tabela 7. Esquema da análise de variância para o delineamento experimental de blocos ao acaso com parcelas subdivididas.

\begin{tabular}{lccc}
\hline Causa de Variação & Graus de Liberdade & Quadrado médio & Valor F \\
\hline Blocos (B) & 2 & QMB & \\
Doses de $\mathrm{K}_{2} \mathrm{O}(\mathrm{K})$ & 4 & QMK & QMK/QMR(a) \\
Resíduo (a) & 8 & QMR(a) & \\
Parcelas & 14 & & \\
Lâminas de Irrigação (W) & 3 & QMW & QMW/QMR(b) \\
Interação K x W & 12 & QMWxK & QMWxK/QMR(b) \\
Resíduo (b) & 30 & QMR(b) & \\
Subparcelas & 59 & & \\
\hline
\end{tabular}




\subsection{Principais características do experimento}

\subsubsection{Histórico do experimento}

O preparo do solo para implantação do experimento relatado por Sousa (2000) consistiu de duas gradagens e incorporação de 2,0 t ha ${ }^{-1}$ de calcário dolomítico em quantidade recomendada pela análise de solo 60 dias antes do transplantio das mudas para elevação da saturação por base a 80\% (Rizzi et al., 1998).

As covas foram abertas no espaçamento de $4,0 \mathrm{~m} \times 3,5 \mathrm{~m}$ e nas dimensões de $0,50 \mathrm{~m}$ de raio e $0,5 \mathrm{~m}$ de profundidade.

Fez-se a adubação de fundação à base de esterco de curral (40L.cova- $\left.{ }^{1}\right) ; \mathrm{P}_{2} \mathrm{O}_{5}$ $\left(200 \mathrm{~g} \cdot \operatorname{cova}^{-1}\right)$, utilizando como fonte superfosfato simples e micronutrientes $\left(4 \mathrm{~g} \cdot \mathrm{cova}^{-1}\right.$ zinco e 1 g.cova ${ }^{-1}$ de boro), segundo a recomendação da análise do solo. O término do plantio ocorreu em 5 de maio de 1999, 15 dias após o preparo das covas, utilizando mudas de maracujazeiro, variedade amarela (Passiflora edulis Sins var. flagicarpa Deg.), preparada em bandejas de polietileno expandido.

A adubação de formação foi realizada à base de nitrogênio e potássio, aplicadas via água de irrigação. A adubação nitrogenada, à base de uréia, consistiu da aplicação, por planta, de $100 \mathrm{~g}$ de $\mathrm{N}$ no período de 0 a 120 dias após o transplantio (DAT), sendo esta quantidade parcelada em 15 aplicações iguais. A adubação potássica foi realizada com cloreto de potássio e consistiu das aplicações: $K_{1}=0,025 \mathrm{~kg}$ por planta; $K_{2}=0,050$ $\mathrm{kg}$ por planta; $\mathrm{K}_{3}=0,075 \mathrm{~kg}$ por planta e $\mathrm{K}_{4}=0,100 \mathrm{~kg}$ por planta no período de 0 a 120 dias após o transplantio (DAT), parcelando-se assim a dose total de $\mathrm{K}$, de cada tratamento, em 15 aplicações iguais. 
A adubação de produção realizada dos 430 dias aos 670 dias após o transplantio de mudas (DAT), segundo ano da cultura, aplicando-se por planta $380 \mathrm{~g}$ de $\mathrm{N}$ e as quantidades de $\mathrm{K}_{2} \mathrm{O}$, com de nitrato de potássio, definidas no item 3.2.

A quantidade de $\mathrm{N}$ e de $\mathrm{K}_{2} \mathrm{O}$ foram definidas a partir da recomendação de adubação de produção apresentada por Melletti \& Maia (1999) e proporcionalizadas conforme a curva de acúmulo de nutriente apresentada por Haag (1973), conforme a Tabela 6. Anteriormente realizou-se uma adubação corretiva de acordo com a Tabela 8.

Tabela 8. Quantidades de nutrientes aplicados de acordo com a análise de solo.

\begin{tabular}{lcc}
\hline Data & Produto & Quantidade \\
\hline $13 / 07 / 2000$ & Calcário dolomítico & $0,460 \mathrm{~kg} \mathrm{planta}{ }^{-1}$ \\
$20 / 07 / 2000$ & Super simples & $0,078 \mathrm{~kg} \mathrm{planta}{ }^{-1}$ \\
& Adubação Foliar* & Concentração \\
$28 / 07 / 2000$ & Ácido bórico & $1 \mathrm{ml} . \mathrm{L}^{-1}$ \\
& Molibdato de sódio & $0,1 \mathrm{ml} \cdot \mathrm{L}^{-1}$ \\
& Sulfato de zinco & $3 \mathrm{ml} \cdot \mathrm{L}^{-1}$ \\
& Sulfato de magnésio & $20 \mathrm{ml} \cdot \mathrm{L}^{-1}$ \\
& Sulfato de cobre & $5 \mathrm{ml} \cdot \mathrm{L}^{-1}$ \\
\hline
\end{tabular}

*a adubação foliar foi realizada com base na análise foliar e de acordo com as recomendações descritas por Ruggiero et al. (1996).

\subsection{Irrigação e fertilização}

Utilizou-se o sistema de irrigação por gotejamento para aplicação de água e fertilizantes (nitrato de potássio, cloreto de potássio e uréia). Em cada linha de plantas 
havia duas linhas de gotejadores: uma linha para irrigação e outra para fertirrigação (Figura 3). As linhas de irrigação possuíam em cada ponto de emissão diferentes números de gotejadores com diferentes vazões $\left(2,4 \mathrm{~L} \mathrm{~h}^{-1}\right.$ e $\left.4,0 \mathrm{~L} \mathrm{~h}^{-1}\right)$, dispostos ao redor da planta, possibilitando a aplicação das quantidades de água por planta em função do tratamento de irrigação pré-estabelecido. Já as linhas para fertirrigação possuíam 2 gotejadores de $2,4 \mathrm{~L} \mathrm{~h}^{-1}$ para cada planta, de forma que cada tratamento de fertilização potássica, disposto em linha, recebeu a quantidade de $\mathrm{K}_{2} \mathrm{O}$ definida.

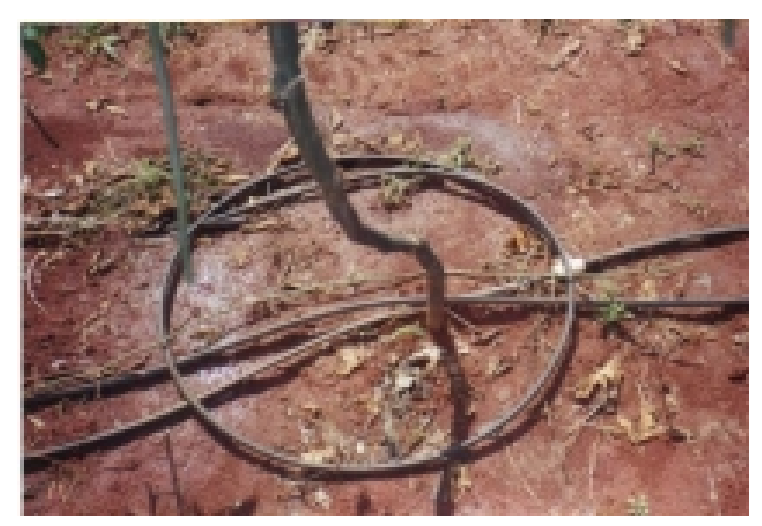

Figura 2 - Detalhe do sistema de irrigação (ao redor da planta) e fertirrigação (linha longitudinal).

O momento da irrigação foi definido pelo potencial mátrico da água no solo, medido em tensiômetros instalados em torno da planta a $0,10 \mathrm{~m} ; 0,30 \mathrm{~m} ; 0,50 \mathrm{~m}$ e 0,70 $\mathrm{m}$ de profundidade no perfil do solo. Irrigava-se toda vez que o potencial mátrico medido a $0,30 \mathrm{~m}$ de profundidade atingia um certo valor entre $10 \mathrm{kPa}$ e $15 \mathrm{kPa}$. A parcela utilizada como referência para o controle da irrigação era aquela que possuía 5 gotejadores de $4,0 \mathrm{~L} \mathrm{~h}^{-1}$ por planta.

Definido o momento da irrigação, as quantidades aplicadas foram determinadas em função do balanço médio de água realizado em quatro lisímetros de drenagem, 
localizados no centro da área experimental, contendo uma planta irrigada por 5 gotejadores de $4 \mathrm{~L} \mathrm{~h}^{-1}$, uniformemente espaçados e dispostos em uma circunferência de 0,50 m de diâmetro, cujo centro era a planta, semelhante à parcela de referência para controle do momento de irrigação.

Para o cálculo do volume de irrigação necessário à parcela de referência considerava-se como entrada de água no lisímetro o volume correspondente à última irrigação mais fertirrigação e a precipitação pluviométrica no período. Como saída considerava-se a drenagem medida no lisímetro a 0,60 $\mathrm{m}$ de profundidade e a evapotranspiração da cultura.

O tempo de irrigação correspondente à lâmina máxima (W), 100\% do consumo medido nos lisímetros, foi determinado pela mesma metodologia utilizada por Sousa (2000) equação 1 :

$$
\mathrm{Ti}=\left[\frac{\mathrm{Tia}-0,05 \mathrm{Vd}}{0,90}\right]
$$

em que:

Ti - tempo de irrigação (h);

Tia - tempo de irrigação anterior (h);

Vd - volume médio de água drenado nos lisímetros (L).

Como a fertirrigação foi feita por meio de linhas laterais independentes, a água fornecida por meio dessas durante a aplicação dos fertilizantes foi considerada no 
cálculo da lâmina máxima aplicada. Nesse caso, o tempo de irrigação foi calculado pela equação 2:

$\mathrm{Ti}=\left[\frac{\mathrm{Tia}-0,05 \mathrm{Vd}}{0,90}\right]-0,24 \mathrm{Tf}$

em que:

Tf - tempo de fertirrigação (h).

A lâmina máxima de irrigação foi calculada utilizando a equação 3:

$\mathbf{W}=\frac{\mathbf{n g} \mathbf{q} \mathbf{T i}}{\mathrm{A}}$

em que:

W - lâmina de máxima de irrigação (mm)

ng - número de gotejadores dentro do lisímetro (5 gotejadores);

q - vazão dos gotejadores $\left(4,0 \mathrm{~L} \mathrm{~h}^{-1}\right)$;

A - área do lisímetro $\left(1,23 \mathrm{~m}^{2}\right)$.

\subsection{Manejo da cultura}

O controle de ervas daninhas foi feito roçagem nas entrelinhas e capinas manuais na forma de coroamento na linha das plantas, de maneira a manter as plantas isentas de concorrências com plantas invasoras. Para o controle de pragas e doenças foram feitas pulverizações preventivas, periodicamente, com inseticidas; acaricida; fungicidas e nematicidas específicos para a cultura e adequados a cada situação, descrita na Tabela 9. 
Tabela 9. Pulverizações realizadas durante a condução do experimento para o controle de pragas e doenças.

\begin{tabular}{cccc}
\hline Data & Produto & Concentração & Observações \\
\hline $11 / 10 / 2000$ & Lebaycid 500 & $1 \mathrm{ml} \mathrm{L}^{-1}$ de água & Inseticida \\
$19 / 11 / 2000$ & Cobre Sandoz 500 & $2,4 \mathrm{~g} \mathrm{~L}^{-1}$ de água & Fungicida \\
$16 / 01 / 2001$ & Decis 25 CE & $1 \mathrm{ml} \mathrm{L}^{-1}$ de água & Inseticida \\
$16 / 01 / 2001$ & Dithane PM & $1 \mathrm{ml} \mathrm{L}^{-1}$ de água & Fungicida \\
\hline
\end{tabular}

No primeiro ano a condução da cultura foi feita por espaldeiras verticais, com um fio de arame liso $\mathrm{n}^{\mathrm{o}} 12$, preso e esticado por mourões espaçados de $4 \mathrm{~m}$. As plantas jovens foram tutoradas com fios de barbante, de forma a permitir a fixação das ramas nas espaldeiras. As plantas foram conduzidas com duas brotações, ou ramos laterais. Esses cresceram de forma monitorada para facilitar a poda de renovação, as práticas de polinização e colheita. Durante a condução da planta foram feitas desbrotas periódicas para assegurar o crescimento apenas da haste até a altura do fio de arame. Fez-se periodicamente a poda de formação, eliminando-se as brotações laterais da guia principal a fim de conduzir a muda em haste única até que ultrapassasse $0,20 \mathrm{~m}$ do arame de sustentação quando se eliminou a gema apical para estimular as brotações laterais.

Como o maracujazeiro apresentou um crescimento contínuo e vigoroso no início do experimento, realizou-se uma poda de renovação aos 500 dias após o transplantio (DAT) (Figura 3). Anteriormente foi realizada a adubação de acordo com a análise do solo (Tabela 8). 


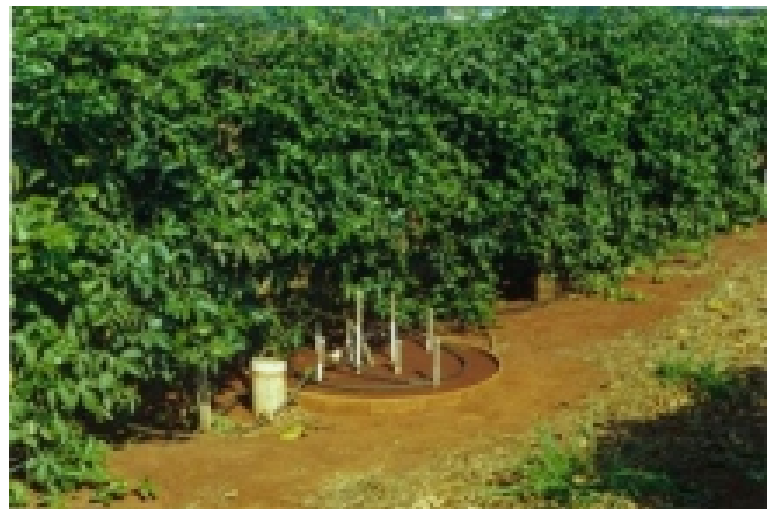

a)

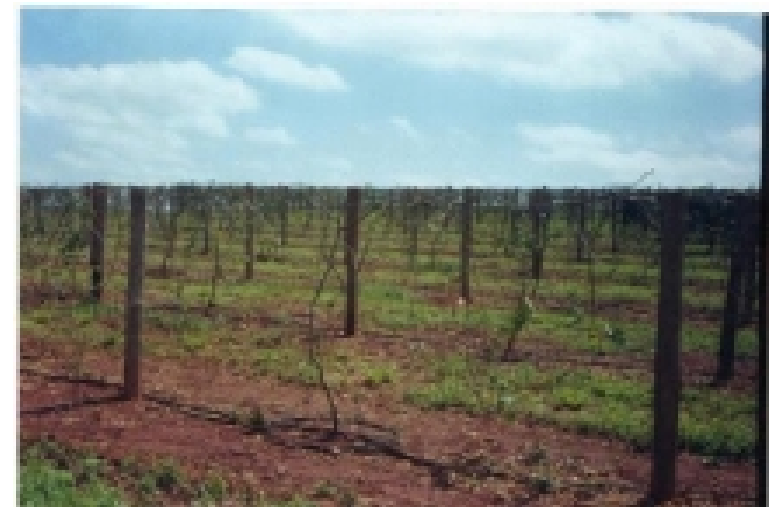

b)

Figura 3 - Vista das plantas antes da poda aos 410 DAT (a) e plantas aos 500 DAT após a poda de renovação (b).

Referente a polinização, os besouros mamangavas (Xylocopa sp) são os principais agentes polinizadores do maracujazeiro amarelo. Todavia, caso o número destes no pomar não seja suficiente para manter a polinização das flores a nível adequado, é adotada a polinização manual. Neste trabalho fez-se a polinização manual a medida que as flores foram surgindo, já que devido a poda, o florescimento não ocorreu de forma regular, conforme recomendação de Ruggiero et al. (1996).

\subsection{Parâmetros avaliados}

Os parâmetros avaliados durante a fase de produção do maracujazeiro foram: o estado nutricional da planta, o comportamento morfológico, produtividade física e econômica, qualidades física e química de frutos e classificação de frutos. 


\subsubsection{Estado nutricional das plantas}

$\mathrm{O}$ estado nutricional das plantas foi determinado através de diagnose foliar, ao final da fase de produção da cultura, última semana de maio, segundo a metodologia para análise em material vegetal descrita em Malavolta et al.(1989). As amostras de folhas foram coletadas em ramos medianos, a partir da quarta folha da ponta e em seguida levadas ao laboratório para as determinações de macronutrientes $(\mathrm{N}, \mathrm{P}, \mathrm{K}, \mathrm{Ca}$, Mg e S) e micronutrientes (B, $\mathrm{Cu}, \mathrm{Fe}, \mathrm{Mn}, \mathrm{e} \mathrm{Zn}$ ).

\subsubsection{Colheita, produtividade e classificação de frutos}

A colheita teve início em 01/12/2000 e encerrou-se em 31/05/2001, com frequiência de duas a três vezes por semana, dependendo do número de frutos que atingiam o ponto de maturação fisiológica $\left({ }^{\circ}\right.$ Brix em torno de $\left.14 \%\right)$, identificados pela mudança na coloração da casca para amarelo. Os frutos colhidos foram contados, pesados e retiradas amostras para as determinações químicas e físicas de qualidade. Os frutos foram classificados e a produção dividida em física (frutos comerciais e não comerciais) e econômica (frutos comerciais). Foram considerados frutos de valor comercial aqueles com peso acima de $45 \mathrm{~g}$ e com boa aparência sem deformações ou estragados, enquanto que frutos danificados foram considerados aqueles picados por percevejo, mosca das frutas ou que caíram ao solo com sintomas de ataque de pragas ou doenças. 
A classificação dos frutos foi feita por peso de acordo com a classificação adotada pelo CEAGESP apresentada em Meletti \& Maia (1999) em 5 tipos: Extra AAA (>173g), Extra AA (144 - 173g), Extra A (108 - 144g), Extra $(86$ - 108g) e Especial (45 $-86 g)$

\subsubsection{Parâmetros de qualidade de frutos}

Os parâmetros físicos de qualidade de frutos avaliados foram: peso médio, diâmetro, comprimento, espessura da casca, densidade do suco e rendimento de suco; e os parâmetros químicos: conteúdo de sólidos solúveis ( ${ }^{\circ}$ Brix), acidez titulável e $\mathrm{pH}$.

A amostragem para as determinações das características de qualidade tanto física quanto química, foram retiradas de frutos colhidos durante os três primeiros meses (dezembro a fevereiro) de colheita. A determinação do peso, diâmetro e comprimento foram realizadas em todos os frutos comerciais colhidos no período de dezembro a fevereiro e as demais determinações físicas em frutos comerciais com as melhores qualidades.

Para as características químicas dos frutos foram tomadas 3 amostras por tratamento, em cada bloco e encaminhadas ao laboratório para a realização das análises. 


\subsubsection{Parâmetros de desenvolvimento das plantas}

As características morfológicas de desenvolvimento das plantas avaliadas foram: diâmetro de caule, comprimento de internós (medidos com paquímetro e régua) e área foliar. O diâmetro do caule foi medido na altura de $1,0 \mathrm{~m}$ e o comprimento de internós foi determinado em três posições do caule da planta: internós localizados a 1,0 m, intermediário e penúltimo.

A área foliar foi medida utilizando-se uma metodologia descrita em Villa Nova et al. (2000), que se baseia em medidas da transmissão da luz direta e difusa pelas folhas.

A análise do sistema radicular foi realizada de acordo com a metodologia descrita em Sousa (2000) baseada na análise de imagens processadas através do "software” Sistema Integrado para Análise de Raízes e Cobertura do Solo, desenvolvido pela EMBRAPA. 


\section{RESULTADOS E DISCUSSÃO}

\subsection{Manejo da irrigação}

Realizou-se o manejo da irrigação de modo a aplicar as lâminas de água definidas para os diferentes tratamentos. A Tabela 10 apresenta as lâminas mensais (irrigações mais fertirrigações) e precipitação pluviométrica. Em média foram aplicados $\mathrm{W}_{1}: 0,29 \mathrm{ET}, \mathrm{W}_{2}: 0,54 \mathrm{ET}, \mathrm{W}_{3}: 0,78 \mathrm{ET}$ e $\mathrm{W}_{4}: 1,00 \mathrm{ET}$, totalizando $63,3,118,5,171,5$ e $220,5 \mathrm{~mm}$, respectivamente.

Tabela 10. Lâminas mensais de irrigação $(\mathrm{mm})$ aplicadas durante o experimento.

\begin{tabular}{lccccc}
\hline Meses & $\begin{array}{c}\text { Precipitação } \\
(\mathrm{mm})\end{array}$ & $\mathrm{W}_{1}$ & \multicolumn{3}{c}{ Irrigação + Fertirrigação $(\mathrm{mm})$} \\
& 5,3 & 6,8 & $\mathrm{~W}_{2}$ & $\mathrm{~W}_{3}$ & $\mathrm{~W}_{4}$ \\
\hline Maio & 5,2 & 4,5 & 8,6 & 16,5 & 21,3 \\
Junho & 60,4 & 3,7 & 7,8 & 12,7 & 16,9 \\
Julho & 84,4 & 10,0 & 16,9 & 23,3 & 14,9 \\
Agosto & 91,2 & 5,5 & 10,6 & 15,7 & 30,8 \\
Setembro & 114,2 & 6,6 & 12,8 & 18,6 & 20,5 \\
Outubro & 239,2 & 3,4 & 6,8 & 10,2 & 13,53 \\
Novembro & 174,5 & 4,2 & 8,3 & 12,5 & 16,7 \\
Dezembro & 229,6 & 4,2 & 8,3 & 12,4 & 16,59 \\
Janeiro & 92,7 & 2,2 & 4,4 & 6,1 & 6,7 \\
Fevereiro & 164,2 & 5,2 & 9,89 & 14,5 & 17,9 \\
Março & 24,1 & 5,2 & 9,5 & 13,1 & 14,4 \\
Abril & 60,6 & 1,8 & 3,1 & 4,2 & 5,6 \\
Maio & $\mathbf{1 3 4 5 , 6}$ & $\mathbf{6 3 , 3}$ & $\mathbf{1 1 8 , 5}$ & $\mathbf{1 7 1 , 5}$ & $\mathbf{2 2 0 , 5}$ \\
Total & & & & &
\end{tabular}


As lâminas de irrigação aplicadas durante o experimento proporcionaram umidade do solo acima da capacidade de campo (CC), praticamente em todos os tratamentos utilizados para o manejo da irrigação, principalmente na profundidade de 0,30 m utilizada para o controle da irrigação, conforme apresentado na Tabela 11 .

Tabela 11. Valores médios de umidade do solo.

\begin{tabular}{|c|c|c|c|c|c|c|c|c|c|}
\hline Me & et & ut & & Dez & W & $x^{2}$ & Ia & br & Mai \\
\hline & \multicolumn{9}{|c|}{ Umidade $\mathrm{cm}^{3} \mathrm{~cm}^{-3}\left(\mathrm{~W}_{1} \mathrm{~K}_{1}\right)$} \\
\hline 0,10 & 789 & 0,3534 & 1045 & 0,4377 & 0,3976 & 0,4377 & 0,2942 & 0,43 & 10.400 \\
\hline 0,30 & 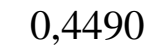 & 4490 & 0 & 0,4213 & 0,4490 & 0,4490 & & & 4490 \\
\hline 0,50 & 0 & 4603 & 0,4394 & 0,4 & 0,4303 & 0,4149 & & & 0,4603 \\
\hline 0,70 & 76 & 0,3709 & 776 & 0,3843 & 0,3 & 0,4526 & 0,3 & & 0,4165 \\
\hline \multicolumn{10}{|c|}{ Umidade $\mathrm{cm}^{3} \mathrm{~cm}^{-3}\left(\mathrm{~W}_{2} \mathrm{~K}_{2}\right)$} \\
\hline 0,10 & 0,3268 & 0,3050 & 0,3486 & 0,3 & 0,2 & 0,3050 & 0,3 & & 4240 \\
\hline 0,30 & 0 & 8 & 5 & 0 , & 65 & 0,4490 & & & 0 \\
\hline 0,50 & & 0,4250 & 0,4603 & 0,4 & 0,4603 & 0,4241 & & & 0,4603 \\
\hline 0,70 & & & 603 & 0,4603 & 0,4202 & 0,4603 & & & 4000 \\
\hline \multicolumn{10}{|c|}{ Umidade $\mathrm{cm}^{3} \mathrm{~cm}^{-3}\left(\mathrm{~W}_{3} \mathrm{~K}_{3}\right)$} \\
\hline 0,1 & 12770 & 0,43 & 0,4377 & 0,4377 & 0,3264 & 0,3701 & 0, & & 77 \\
\hline 0 & & 7 & & 0 & 0 & 0,4490 & & & 0 \\
\hline 0,50 & 4603 & 0,4603 & 0,46030 & 0,4603 & 0,4 & 0,4603 & 0,4 & & 0,4603 \\
\hline 0,70 & & 0,4603 & 0,4603 & 0,4603 & 0,3654 & 0,3754 & 0,38 & & 0,3769 \\
\hline \multicolumn{10}{|c|}{ Umidade $\mathrm{cm}^{3} \mathrm{~cm}^{-3}\left(\mathrm{~W}_{4} \mathrm{~K}_{4}\right)$} \\
\hline & & & 372 & 0,3909 & 0,2855 & 0,3141 & 0, & & 7 \\
\hline 0 & & & & & 0,4 & 0,4490 & & & 0 \\
\hline & & & & & & 0,3950 & & & 0 \\
\hline & & & & & & & & & \\
\hline 0,3 & & & & & & 0,4 & & & \\
\hline 0 & 0,4490 & 0,4490 & 0,4490 & 0,4490 & 0,4490 & 0,4490 & $\mathbf{0 , 4}$ & & 0,4490 \\
\hline
\end{tabular}

Autores como Menzel et al. (1986a), Staveley \& Wolstenholme (1990) e Vasconcelos (1994) recomendam manter a umidade do solo próxima a CC para a cultura do maracujazeiro, especialmente no florescimento e pegamento dos frutos. Apesar da 
alta umidade do solo a cultura não sentiu efeitos do excesso de umidade, o que poderia ocasionar prejuízos ao sistema radicular da cultura, como incidência de doenças. Até 0,10 m de profundidade ocorreu a maior variação da umidade do solo em todos os níveis de irrigação, em consequiência da maior competição entre as plantas de maracujá e plantas daninhas quando estas existiam, do movimento vertical da água no solo e das perdas por evaporação.

\subsection{Condutividade elétrica da solução do solo}

O monitoramento da fertirrigação foi realizado utilizando-se resultados da análise da solução do solo coletada por extratores instalados nos tratamentos $\mathrm{W}_{1} \mathrm{~K}_{1}$, $\mathrm{W}_{2} \mathrm{~K}_{2}, \mathrm{~W}_{3} \mathrm{~K}_{3}$ e $\mathrm{W}_{4} \mathrm{~K}_{4}$. Assim foi possível determinar a condutividade elétrica da solução do solo e acompanhar a concentração de sais na solução aplicada via irrigação e o acúmulo de sais no solo evitando prejudicar a atividade do sistema radicular.

A condutividade elétrica da solução do solo (CE) apresentou valores baixos em todos os tratamentos, variando de $0,00972 \mathrm{dSm}^{-1} \mathrm{em} \mathrm{W}_{2} \mathrm{~K}_{2}$ até $0,573 \mathrm{dSm}^{-1} \mathrm{em} \mathrm{W}_{4} \mathrm{~K}_{4}$, bem abaixo dos valores de CE encontrados por Sousa (2000) no primeiro ano de produção desse experimento, mesmo com o aumento gradativo das doses de potássio programadas para o ciclo da cultura.

A Figura 4 mostra que a CE foi maior na profundidade de $0,70 \mathrm{~m}$, indicando provável lixiviação de íons, provocada muito mais pela alta precipitação pluviométrica no período do que pelas diferenças de lâminas aplicadas nos tratamentos. O tratamento 
$\mathrm{W}_{1} \mathrm{~K}_{1}$ apresentou os menores valores de $\mathrm{CE}$, inferiores a $0,20 \mathrm{dSm}^{-1}$, enquanto que os maiores valores foram verificados no tratamento de $\mathrm{W}_{4} \mathrm{~K}_{4}$.

Ayers \& Westcot ${ }^{1}$ citados por Sousa (2000) afirmam que o maracujazeiro é uma cultura sensível à salinidade e um valor adequado da condutividade elétrica do extrato de saturação, não deve exceder a 1,3 $\mathrm{dSm}^{-1}$. Esse valor não foi excedido nesse experimento.
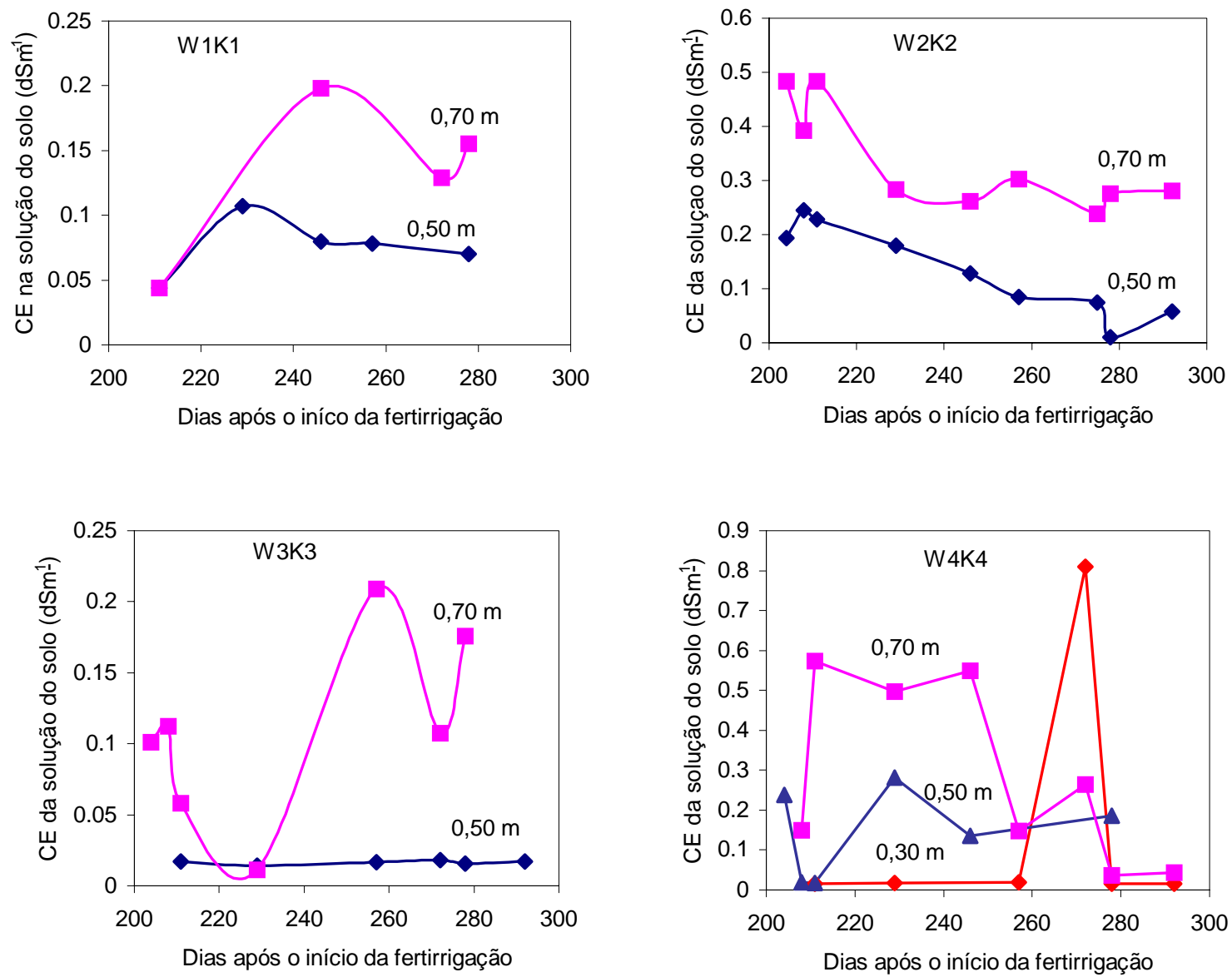

Figura 4 - Condutividade elétrica da solução do solo nos tratamentos.

\footnotetext{
${ }^{1}$ AYERS, R. S.,; WESTCOT, D. W. A qualidade da água na agricultura. Campina Grande: UFPB, 1991. 218p.
} 


\subsection{Concentração de potássio no solo}

A absorção de potássio pelas plantas pode ser afetada por vários fatores, dentre eles, a concentração de potássio na solução do solo que deve manter níveis adequados para suprir as necessidades da plantas. Neste experimento, a concentração de potássio determinada na solução do solo apresentou maiores valores na profundidade de $0,70 \mathrm{~m}$ (Figura 5), sendo que o tratamento $\mathrm{W}_{4} \mathrm{~K}_{4}$ apresentou o maior valor $\left(774 \mathrm{mg} \cdot \mathrm{kg}^{-1}\right)$ entre os tratamentos, com a aplicação de duas vezes a dose recomendada. Já o tratamento $\mathrm{W}_{3} \mathrm{~K}_{3}$ foi o que apresentou menor valor de concentração de potássio. Como para a condutividade elétrica, a alta concentração de potássio na profundidade de $0,70 \mathrm{~m}$ pode ser atribuída a alta precipitação pluviométrica durante período experimental.

Na Figura 5 observa-se que as menores concentrações de potássio foram verificadas nos tratamentos $\mathrm{W}_{1} \mathrm{~K}_{1}$ e $\mathrm{W}_{3} \mathrm{~K}_{3}$ e as maiores nos tratamentos $\mathrm{W}_{2} \mathrm{~K}_{2}, \mathrm{~W}_{3} \mathrm{~K}_{3}$ (0,70 $\mathrm{m}$ de profundidade) e $\mathrm{W}_{4} \mathrm{~K}_{4}$. A observação de íon $\mathrm{K}^{+}$na profundidade de $0,70 \mathrm{~m}$ pode ser atribuída à lixiviação por chuvas e irrigação como constatado por Sousa (2000) e por Espinoza \& Reis $^{2}$ citados por Sousa (2000), que verificaram elevadas concentrações de $\mathrm{K}^{+}$a 1,05 m de profundidade após fortes chuvas.

\footnotetext{
${ }^{2}$ ESPINOZA, W.; REIS A E. G. Lixiviação de Ca, K e Mg em um Latossolo Vermelho-Escuro (LE) de Cerrados. I. Magnitude e variabilidade do fenômeno de época chuvosa. Pesquisa Agropecuária Brasileira, v.17, n.2, p.299-317, 1982.
} 

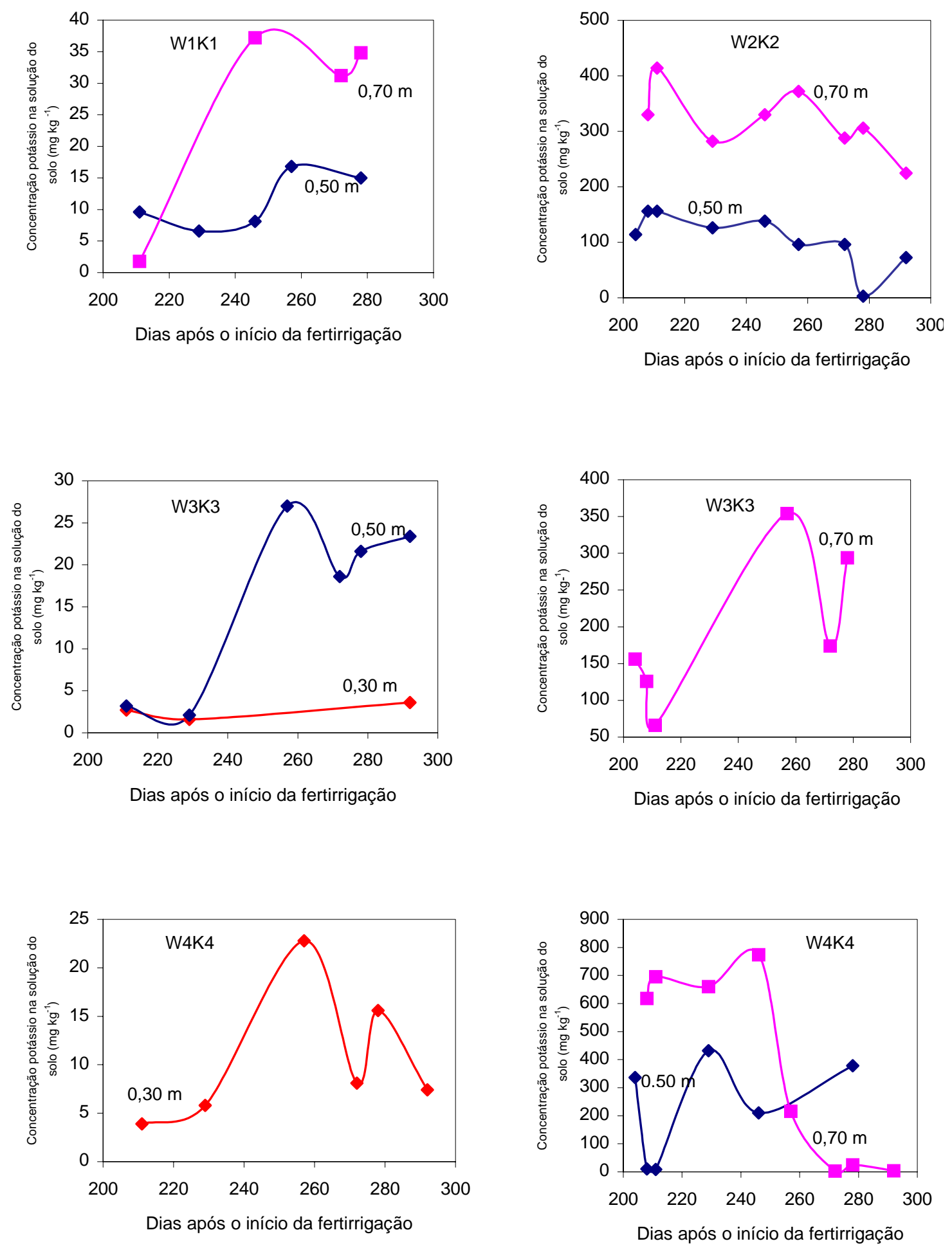

Figura 5 - Concentração de potássio na solução do solo. 


\subsection{Diâmetro de caule e comprimento de internós}

A avaliação das características morfológicas é importante quando se trata da fertirrigação, já que água e nutrientes afetam diretamente o desenvolvimento da planta, tanto pelo excesso quanto pela falta. Os resultados da análise de variância para o diâmetro de caule e comprimento de internós estão apresentados na Tabela 12.

Tabela 12. Resumo da análise de variância para características morfológicas: diâmetro de caule e comprimento de internós do maracujazeiro amarelo.

\begin{tabular}{lccc}
\hline Causa de Variação & G.L & \multicolumn{2}{c}{ Quadrado Médio (Valor de F) } \\
& & Diâm. de caule & Comp. internós \\
\hline Blocos (B) & 2 & 117,1111 & 1169,266 \\
Doses de $\mathrm{K}_{2} \mathrm{O}(\mathrm{K})$ & 4 & $31,63965\left(1,24^{\mathrm{ns}}\right)$ & $377,3312\left(2,23^{\mathrm{ns}}\right)$ \\
Resíduo (a) & 12 & 25,47477 & 168,8884 \\
Parcelas & 14 & & \\
Lâminas de Irrigação (W) & 3 & $42,1862\left(3,48^{*}\right)$ & $503,1082\left(2,33^{\mathrm{ns}}\right)$ \\
Interação K x W & 12 & $13,30145\left(1,10^{\mathrm{ns}}\right)$ & $143,5069\left(0,66^{\mathrm{ns}}\right)$ \\
Resíduo (b) & 30 & 12,11499 & 216,3773 \\
Subparcelas & 59 & & \\
\hline * significativo ao nível de 5\% de probabilidade pelo teste F \\
ns não significativo ao nível de 5\% de probabilidade pelo teste F
\end{tabular}

A análise de variância mostrou efeito significativo, a de 5\% de probabilidade pelo teste $\mathrm{F}$, das lâminas de irrigação no diâmetro de caule, confirmando o papel marcante da água no desenvolvimento da planta. O menor valor de diâmetro de caule observado foi 19,42 mm (combinação $\mathrm{W}_{3} \mathrm{~K}_{2}$ ) e o maior valor foi 28,20 mm (combinação $\mathrm{W}_{4} \mathrm{~K}_{4}$ ), sendo $23,10 \mathrm{~mm}$ o valor médio. Observa-se na Tabela 13 que, em média, o efeito das lâminas de irrigação apresentou uma tendência quadrática, embora não significativa através da análise de regressão. 
Tabela 13. Valores médios de diâmetro de caule (mm)

\begin{tabular}{cccccc}
\hline $\begin{array}{c}\text { Doses de } \mathrm{K}_{2} \mathrm{O} \\
\left(\mathrm{kg} \mathrm{planta}^{-1}\right)\end{array}$ & $63,3\left(\mathrm{~W}_{1}\right)$ & $118,5\left(\mathrm{~W}_{2}\right)$ & $171,5\left(\mathrm{~W}_{3}\right)$ & $220,5\left(\mathrm{~W}_{4}\right)$ & Média \\
\hline $0,00\left(\mathrm{~K}_{0}\right)$ & 26,33 & 22,07 & 19,82 & 24,72 & $\mathbf{2 3 , 2 3}$ \\
$0,200\left(\mathrm{~K}_{1}\right)$ & 23,37 & 20,68 & 19,42 & 22,97 & $\mathbf{2 1 , 6 1}$ \\
$0,400\left(\mathrm{~K}_{2}\right)$ & 24,27 & 19,45 & 23,87 & 24,27 & $\mathbf{2 2 , 9 6}$ \\
$0,600\left(\mathrm{~K}_{3}\right)$ & 22,02 & 26,33 & 21,15 & 28,20 & $\mathbf{2 4 , 4 2}$ \\
$0,800\left(\mathrm{~K}_{4}\right)$ & 23,42 & 20,55 & 23,90 & 25,27 & $\mathbf{2 3 , 2 8}$ \\
Média & $\mathbf{2 3 , 8 8}$ & $\mathbf{2 1 , 8 1}$ & $\mathbf{2 1 , 6 3}$ & $\mathbf{2 5 , 0 8}$ & $\mathbf{2 3 , 1}$ \\
\hline
\end{tabular}

Para o comprimento de internos, a análise de variância não revelou efeito significativo da irrigação e da adubação potássica, a 5\% de probabilidade pelo teste $\mathrm{F}$ (Tabela 12), obtendo um valor médio de 97,21 mm. Porém, verifica-se pela Tabela 14 que, em média, lâminas de irrigação crescentes até $171,5 \mathrm{~mm}$ tenderam a produzir maiores comprimentos de internós. De acordo com Menzel et al. (1986a), como efeito da redução do teor de água no solo, o maracujazeiro produz ramos menores com menor número de nós e comprimento de internós, refletindo no número de botões florais e flores abertas.

Tabela 14. Valores médios do comprimento de internós (mm).

\begin{tabular}{cccccc}
\hline $\begin{array}{l}\text { Doses de } \mathrm{K}_{2} \mathrm{O} \\
\left(\mathrm{kg} \mathrm{planta}^{-1}\right)\end{array}$ & $63,3\left(\mathrm{~W}_{1}\right)$ & \multicolumn{3}{c}{ Lâminas totais de água $(\mathrm{mm})$} \\
\hline $0,00\left(\mathrm{~K}_{0}\right)$ & 92,19 & 95,58 & 95,73 & 106,06 & $\mathbf{9 7 , 4 6}$ \\
$0,200\left(\mathrm{~K}_{1}\right)$ & 91,33 & 87,01 & 95,29 & 88,13 & $\mathbf{9 0 , 4 4}$ \\
$0,400\left(\mathrm{~K}_{2}\right)$ & 100,77 & 110,22 & 97,36 & 89,67 & $\mathbf{9 9 , 5 0}$ \\
$0,600\left(\mathrm{~K}_{3}\right)$ & 92,63 & 101,76 & 110,73 & 87,23 & $\mathbf{9 8 , 0 8}$ \\
$0,800\left(\mathrm{~K}_{4}\right)$ & 86,84 & 101,31 & 111,23 & 103,09 & $\mathbf{1 0 0 , 6 1}$ \\
Média & $\mathbf{9 2 , 7 5}$ & $\mathbf{9 9 , 2 3}$ & $\mathbf{1 0 2 , 0 6}$ & $\mathbf{9 4 , 8 3}$ & $\mathbf{9 7 , 2 1}$ \\
\hline
\end{tabular}




\section{5 Área foliar}

A área foliar medida aos 474 DAT foi afetada significativamente pelas lâminas de irrigação, ao nível de $5 \%$ de probabilidade pelo teste $\mathrm{F}$ (Tabela 15). Com relação às doses de potássio, a área foliar não foi afetada significativamente, embora Manica (1981), Kliemann et al. (1986), Baumgartner (1987) e Ruggiero et al. (1996) afirmam que a deficiência de potássio no maracujazeiro ocasiona redução na área foliar, afetando a fotossíntese.

Tabela 15. Resumo da análise de variância para a característica morfológica área foliar do maracujazeiro amarelo.

\begin{tabular}{lcc}
\hline Causa de Variação & G.L & $\begin{array}{c}\text { Quadrado Médio (Valor de F) } \\
\text { Área Foliar }\end{array}$ \\
\hline Blocos (B) & 1 & 4,395778 \\
Doses de $\mathrm{K}_{2} \mathrm{O}(\mathrm{K})$ & 4 & $14,26606\left(4,03^{\mathrm{ns}}\right)$ \\
Resíduo (a) & 4 & 3,536291 \\
Parcelas & 9 & \\
Lâminas de Irrigação (W) & 3 & $19,02141\left(18,00^{*}\right)$ \\
Interação K x W & 12 & $2,003783\left(1,90^{\text {ns }}\right)$ \\
Resíduo (b) & 15 & 1,056776 \\
Subparcelas & 39 & \\
\hline
\end{tabular}

* significativo ao nível de 5\% de probabilidade pelo teste $\mathrm{F}$.

ns não significativo ao nível de 5\% de probabilidade pelo teste $\mathrm{F}$.

Neste experimento, a menor área foliar foi constatada no tratamento $\mathrm{W}_{2} \mathrm{~K}_{0}(5,10$ $\mathrm{m}^{2}$ por planta) enquanto a maior foi verificada no tratamento $\mathrm{W}_{3} \mathrm{~K}_{3}\left(10,50 \mathrm{~m}^{2}\right.$ por planta) (Tabela 16). 
Tabela 16. Valores médios da área foliar do maracujazeiro amarelo ( $\mathrm{m}^{2}$ por planta)

\begin{tabular}{cccccc}
\hline $\begin{array}{c}\text { Doses de } \mathrm{K}_{2} \mathrm{O} \\
(\mathrm{kg} \mathrm{planta})\end{array}$ & $63,3\left(\mathrm{~W}_{1}\right)$ & $118,5\left(\mathrm{~W}_{2}\right)$ & $171,5\left(\mathrm{~W}_{3}\right)$ & $220,5\left(\mathrm{~W}_{4}\right)$ & Média \\
\hline $0,00\left(\mathrm{~K}_{0}\right)$ & 8,10 & 5,10 & 10,04 & 9,44 & $\mathbf{8 , 1 7}$ \\
$0,200\left(\mathrm{~K}_{1}\right)$ & 7,43 & 5,54 & 8,95 & 7,52 & $\mathbf{7 , 3 6}$ \\
$0,400\left(\mathrm{~K}_{2}\right)$ & 8,10 & 6,66 & 7,24 & 6,49 & $\mathbf{7 , 1 2}$ \\
$0,600\left(\mathrm{~K}_{3}\right)$ & 6,51 & 8,72 & 10,50 & 6,90 & $\mathbf{8 , 1 5}$ \\
$0,800\left(\mathrm{~K}_{4}\right)$ & 7,16 & 8,37 & 9,28 & 6,19 & $\mathbf{7 , 7 5}$ \\
Média & $\mathbf{7 , 4 6}$ & $\mathbf{6 , 8 7}$ & $\mathbf{9 , 2 0}$ & $\mathbf{7 , 3 0}$ & $\mathbf{7 , 7 1}$ \\
\hline
\end{tabular}

Segundo Menzel et al. (1986) e Staveley \& Wolstenholme (1990) o desenvolvimento da área foliar está relacionado com a disponibilidade de água do solo, sendo que o acréscimo no índice de área foliar está associado com o aumento da umidade do solo. Manica (1981) e Ruggiero et al. (1996) afirmam também que a falta de água no solo provoca a queda das folhas reduzindo a área foliar da planta. Já Sousa (2000), durante o primeiro ano desse experimento, verificou efeito linear decrescente dos níveis de irrigação na área foliar do maracujazeiro, em fase inicial de crescimento.

\subsection{Sistema radicular}

O conhecimento da distribuição do sistema radicular é de fundamental importância para praticas culturais como a adubação e a irrigação. A Tabela 17 mostra que $50 \%$ das raízes do maracujazeiro localizaram-se em um raio de até 0,60 m de distância do caule da planta. Carvalho (1988) verificou que 85,46\% do total das raízes foram encontrados em uma faixa de $0,50 \mathrm{~m}$ ao redor do tronco em um pomar de 
maracujazeiro amarelo com dois anos de idade, no entanto essa diferença pode estar na metodologia adotada pelo autor, que fez amostragem com auxílio de trado.

A distribuição de raízes em profundidade apresentou $25 \%$ e $28 \%$ nas camadas de $0,00-0,20 \mathrm{~m}$ e 0,20 - 0,40 m respectivamente, ocorrendo a partir daí uma diminuição gradual, evidenciando a superficialidade do sistema radicular do maracujazeiro. Entretanto, $11 \%$ das raízes encontravam-se a uma profundidade de 0,80 m - 1,00 m de profundidade, o que pode ser atribuído às condições físicas e químicas do solo associadas às tecnologias de irrigação e fertirrigação.

Tabela 17. Distribuição percentual do sistema radicular do maracujazeiro amarelo.

\begin{tabular}{cccccccccccc}
\hline & \multicolumn{10}{c}{ Distância do caule da planta $(\mathrm{m})$} \\
Prof. (cm) & $-0,80$ & $-0,60$ & $-0,40$ & $-0,20$ & 0,00 & 0,20 & 0,40 & 0,60 & 0,80 & Total \\
& & \multicolumn{8}{c}{ Porcentagem } \\
\hline $0,00-0,20$ & 2,62 & 2,70 & 2,56 & 2,63 & 4,92 & 3,68 & 2,63 & 1,84 & 1,41 & $\mathbf{2 5 , 0 0}$ \\
$0,20-0,40$ & 2,82 & 3,76 & 7,33 & 3,35 & 3,07 & 0,67 & 2,06 & 2,63 & 2,44 & $\mathbf{2 8 , 1 4}$ \\
$0,40-0,60$ & 2,70 & 2,36 & 4,92 & 1,62 & 1,87 & 1,19 & 4,77 & 1,37 & 0,61 & $\mathbf{2 1 , 4 3}$ \\
$0,60-0,80$ & 2,91 & 3,39 & 1,68 & 1,38 & 0,84 & 0,45 & 0,87 & 0,93 & 1,87 & $\mathbf{1 4 , 3 2}$ \\
$0,80-1,00$ & 5,45 & 0,64 & 0,72 & 1,25 & 0,29 & 0,62 & 0,14 & 0,97 & 1,02 & $\mathbf{1 1 , 1 1}$ \\
Total & $\mathbf{1 6 , 5 0}$ & $\mathbf{1 2 , 8 6}$ & $\mathbf{1 7 , 2 1}$ & $\mathbf{1 0 , 2 3}$ & $\mathbf{1 1 , 0 0}$ & $\mathbf{6 , 6 2}$ & $\mathbf{1 0 , 4 8}$ & $\mathbf{7 , 7 4}$ & $\mathbf{7 , 3 5}$ & $\mathbf{1 0 0 , 0 0}$ \\
\hline
\end{tabular}

\subsection{Características químicas dos frutos}

A análise de variância (Tabela 18) revelou que as doses de potássio, as lâminas de irrigação e a interação entre esses fatores não afetaram significativamente, ao nível 
$5 \%$ de probabilidade pelo teste $\mathrm{F}$, as características químicas de qualidade dos frutos do maracujazeiro amarelo: sólidos solúveis totais (SST), acidez total titulável (ATT) e pH.

Tabela 18. Resumo da análise de variância para as características químicas do maracujazeiro amarelo.

\begin{tabular}{|c|c|c|c|c|}
\hline \multirow[t]{2}{*}{ Causa de Variação } & \multirow[t]{2}{*}{ G.L } & \multicolumn{3}{|c|}{ Quadrado Médio (Valor de F) } \\
\hline & & SST & $\mathrm{pH}$ & ATT \\
\hline Blocos (B) & 3 & 1,349 & 0,01263 & 0,650 \\
\hline Doses de $\mathrm{K}_{2} \mathrm{O}(\mathrm{K})$ & 4 & $2,577\left(1,55^{\mathrm{ns}}\right)$ & $0,111\left(1,43^{\mathrm{ns}}\right)$ & $0,644\left(1,55^{\mathrm{ns}}\right)$ \\
\hline Resíduo (a) & 12 & 1,6626 & 0,0779 & 0,4156 \\
\hline Parcelas & 19 & & & \\
\hline Lâminas de Irrigação (W) & 3 & $3,436\left(2,22^{\mathrm{ns}}\right)$ & $0,149\left(2,56^{\mathrm{ns}}\right)$ & $0,859\left(3,10^{\mathrm{ns}}\right)$ \\
\hline Interação K x W & 12 & $0,819\left(5,53^{\mathrm{ns}}\right)$ & $0,062\left(1,07^{\mathrm{ns}}\right)$ & $0,351\left(1,27^{\mathrm{ns}}\right)$ \\
\hline Resíduo (b) & 45 & 1,5452 & 0,058136 & 0,2766 \\
\hline Subparcelas & 79 & & & \\
\hline
\end{tabular}

* significativo ao nível de 5\% de probabilidade pelo teste $\mathrm{F}$.

ns não significativo ao nível de 5\% de probabilidade pelo teste $\mathrm{F}$.

Os valores médios de sólidos solúveis totais (SST) (\% de ${ }^{\circ}$ Brix $)$ estão apresentados na Tabela 19. Observa-se que os valores variaram de 14,38\% (tratamento $\mathrm{W}_{1} \mathrm{~K}_{4}$ ) a $16,33 \%$ (tratamento $\mathrm{W}_{3} \mathrm{~K}_{3}$ ), isto é, um acréscimo de $13,56 \%$, embora essa diferença não seja significativa. Em média, houve um acréscimo linear no valor de SST, a partir da dose $\mathrm{K}_{0}$ até a dose $\mathrm{K}_{3}$, à razão de $0,72{ }^{\circ}$ Brix por $\mathrm{kg}$ de $\mathrm{K}_{2} \mathrm{O}$. Para doses maiores de $\mathrm{K}_{2} \mathrm{O}$ o valor de SST diminuiu, atingindo $14,70 \%$ de ${ }^{\circ}$ Brix para $\mathrm{K}_{4}$.

Para a indústria de suco é de interesse que os frutos apresentem elevados teores de sólidos solúveis totais, característica que proporciona menor custo de produção no processamento de suco. Os resultados obtidos neste trabalho atendem a essa exigência, visto que os valores de SST (com valor médio de 15,35\%) encontram-se dentro da faixa ideal para suco de frutos de maracujazeiro $(13,8 \%$ a $18,5 \%)$. 
Tabela 19. Valores médios de teores de sólidos solúveis totais (SST, \% de ${ }^{\circ}$ Brix) em frutos de maracujazeiro amarelo.

\begin{tabular}{cccccc}
\hline $\begin{array}{c}\text { Doses de } \mathrm{K}_{2} \mathrm{O} \\
\left(\mathrm{kg} \mathrm{planta}^{-1}\right)\end{array}$ & \multicolumn{5}{c}{ Lâminas totais de irrigação $(\mathrm{mm})$} \\
\hline $0,00\left(\mathrm{~K}_{0}\right)$ & 15,83 & $118,5\left(\mathrm{~W}_{2}\right)$ & $171,5\left(\mathrm{~W}_{3}\right)$ & $220,5\left(\mathrm{~W}_{4}\right)$ & Média \\
$0,200\left(\mathrm{~K}_{1}\right)$ & 15,30 & 14,75 & 15,80 & 14,85 & $\mathbf{1 5 , 3 0}$ \\
$0,400\left(\mathrm{~K}_{2}\right)$ & 15,80 & 15,18 & 15,40 & 15,28 & $\mathbf{1 5 , 4 5}$ \\
$0,600\left(\mathrm{~K}_{3}\right)$ & 14,95 & 16,09 & 16,50 & 15,93 & $\mathbf{1 5 , 6 0}$ \\
$0,800\left(\mathrm{~K}_{4}\right)$ & 14,38 & 14,75 & 15,05 & 15,58 & $\mathbf{1 5 , 7 3}$ \\
Média & $\mathbf{1 5 , 2 5}$ & $\mathbf{1 5 , 3 2}$ & $\mathbf{1 5 , 6 1}$ & $\mathbf{1 5 , 2 5}$ & $\mathbf{1 5 , 3 5}$ \\
\hline
\end{tabular}

O potássio e a água têm papel importante no conteúdo de sólidos solúveis dos frutos. Embora muitos autores confirmam essa asserção (Medina, 1980; Manica, 1981 e Kliemann et al., 1986), na literatura há alguns resultados divergentes: Sousa (2000) não encontrou efeito significativo das doses de potássio e lâminas de irrigação sobre o teor de sólidos solúveis totais dos frutos, no primeiro ano de produção do maracujazeiro desse experimento. Entretanto, observou que ocorreu um pequeno aumento do Brix com o aumento da lâmina de água aplicada, com uma tendência quadrática, mas não houve tendência definida dessa variável com o aumento das doses de $\mathrm{K}_{2} \mathrm{O}$. Também, Müller (1977), Teixeira (1989) e Colauto et al. (1986) não constataram efeito significativo do potássio no conteúdo de sólidos solúveis de frutos do maracujazeiro. Já Martins (1998) encontrou resposta positiva para ${ }^{\mathrm{O}}$ Brix em relação ao uso de potássio, com valores variando de $13,3 \%$ a $14,4 \%$, inferiores aos obtidos nesse experimento.

Segundo Haendler (1965) e Müller (1977), a baixa disponibilidade de água no solo favorece a colheita de frutos de maracujazeiro com maiores valores de ${ }^{\circ}$ Brix. Neste experimento, a aplicação de menores lâminas de irrigação não promoveu o aumento do 
${ }^{\circ}$ Brix, possivelmente pelo alto índice pluviométrico durante o período de formação e maturação dos frutos.

A acidez total titulável (ATT) variou de 2,86\% (tratamento $\mathrm{W}_{1} \mathrm{~K}_{1}$ ) a 4,30\% (tratamento $\mathrm{W}_{1} \mathrm{~K}_{4}$ ), representando um aumento de 50\% da ATT (Tabela 20), contudo essa diferença não foi significativa ao nível de $5 \%$ de probabilidade pelo teste $\mathrm{F}$ (Tabela 18).

Tabela 20. Valores médios da acidez total titulável dos frutos de maracujá amarelo.

\begin{tabular}{cccccc}
\hline $\begin{array}{c}\text { Doses de } \mathrm{K}_{2} \mathrm{O} \\
\left(\mathrm{kg} \mathrm{planta}^{-1}\right)\end{array}$ & $63,3\left(\mathrm{~W}_{1}\right)$ & $\begin{array}{c}\text { Lâminas totais de irrigação }(\mathrm{mm}) \\
118,5\left(\mathrm{~W}_{2}\right)\end{array}$ & $171,5\left(\mathrm{~W}_{3}\right)$ & $220,5\left(\mathrm{~W}_{4}\right)$ & Média \\
\hline $0,00\left(\mathrm{~K}_{0}\right)$ & 2,91 & 3,31 & 3,23 & 2,88 & $\mathbf{3 , 0 8}$ \\
$0,200\left(\mathrm{~K}_{1}\right)$ & 2,86 & 3,36 & 2,96 & 3,03 & $\mathbf{3 , 0 5}$ \\
$0,400\left(\mathrm{~K}_{2}\right)$ & 3,75 & 3,56 & 3,14 & 3,33 & $\mathbf{3 , 4 4}$ \\
$0,600\left(\mathrm{~K}_{3}\right)$ & 3,33 & 3,39 & 3,31 & 3,16 & $\mathbf{3 , 2 9}$ \\
$0,800\left(\mathrm{~K}_{4}\right)$ & 4,30 & 3,28 & 3,26 & 3,11 & $\mathbf{3 , 4 8}$ \\
Média & $\mathbf{3 , 4 3}$ & $\mathbf{3 , 3 8}$ & $\mathbf{3 , 1 8}$ & $\mathbf{3 , 1 0}$ & $\mathbf{3 , 2 6}$ \\
\hline
\end{tabular}

As doses de potássio de $0,400 \mathrm{~kg}$ e $0,800 \mathrm{~kg}$ de $\mathrm{K}_{2} \mathrm{O}$ por planta proporcionaram os maiores valores médios de ATT iguais a 3,44\% e 3,48\% respectivamente. Observa-se que os valores médios de ATT foram decrescentes com o aumento das lâminas de irrigação, atingindo um máximo de $3,43 \%$ para $63,3 \mathrm{~mm}$, reduzindo-se para $3,10 \%$ para 220,5 mm (Tabela 20). Também Ritzenger et al. (1989), observaram que baixas precipitações associadas a fatores climáticos produziram frutos de maracujá amarelo com maior ATT.

De maneira geral, os valores de ATT obtidos nesse experimento encontram-se dentro dos padrões de qualidade exigidos pela indústria, menor que 4,91\% segundo 
Araújo et al. (1974). Nascimento (1996) sustenta que a acidez natural do maracujá pode diminuir custos de processamento com menor adição de acidificantes artificiais ao suco.

Com relação ao efeito de doses de potássio e água, Martins (1998) e Sousa (2000) não obtiveram evidências de efeito da interação entre essas variáveis na acidez total titulável. No entanto, Sousa (2000), no primeiro ano desse experimento, verificou que a aplicação de níveis de irrigação por gotejamento e doses de potássio via fertirrigação favoreceram a produção de frutos com suco de menor acidez total titulável.

Os valores médios do pH estão apresentados na Tabela 21, onde se pode verificar uma variação máxima de $12 \%$ (3,29 a 3,70), não significativa ao nível de $5 \%$ de probabilidade pelo teste $\mathrm{F}$ (Tabela 18).

Nascimento et al. (1998) verificaram que o pH variou de 2,38 a 3,14 em frutos colhidos em diferentes épocas, valores inferiores aos encontrados nesse trabalho para a mesma época. Também Martins (1998) encontrou valor médio de pH de 2,4. Nesse trabalho os tratamentos testados produziram frutos menos ácidos, concordando com os resultados obtidos por Sousa (2000).

Tabela 21. Valores médios do pH para frutos de maracujá amarelo.

\begin{tabular}{cccccc}
\hline $\begin{array}{c}\text { Doses de } \mathrm{K}_{2} \mathrm{O} \\
\left(\mathrm{kg} \mathrm{planta}^{-1}\right)\end{array}$ & $63,3\left(\mathrm{~W}_{1}\right)$ & $118,5\left(\mathrm{~W}_{2}\right)$ & $171,5\left(\mathrm{~W}_{3}\right)$ & $220,5\left(\mathrm{~W}_{4}\right)$ & Média \\
\hline $0,00\left(\mathrm{~K}_{0}\right)$ & 3,44 & 3,64 & 3,68 & 3,67 & $\mathbf{3 , 6 0}$ \\
$0,200\left(\mathrm{~K}_{1}\right)$ & 3,61 & 3,65 & 3,67 & 3,59 & $\mathbf{3 , 6 3}$ \\
$0,400\left(\mathrm{~K}_{2}\right)$ & 3,56 & 3,54 & 3,29 & 3,31 & $\mathbf{3 , 4 2}$ \\
$0,600\left(\mathrm{~K}_{3}\right)$ & 3,64 & 3,42 & 3,51 & 3,48 & $\mathbf{3 , 5 1}$ \\
$0,800\left(\mathrm{~K}_{4}\right)$ & 3,56 & 3,45 & 3,70 & 3,29 & $\mathbf{3 , 5 0}$ \\
Média & $\mathbf{3 , 5 6}$ & $\mathbf{3 , 5 4}$ & $\mathbf{3 , 5 7}$ & $\mathbf{3 , 4 6}$ & $\mathbf{3 , 5 3}$ \\
\hline
\end{tabular}




\subsection{Características físicas do fruto}

A análise de variância, apresentada na Tabela 22, mostra que os níveis de irrigação, as doses de $\mathrm{K}_{2} \mathrm{O}$ e a interação entre esses fatores tiveram efeito significativo na densidade do suco, espessura da casca e rendimento de suco. A Tabela 23 apresenta a análise de variância para o peso, comprimento e diâmetro do fruto. Verifica-se o efeito significativo da irrigação e da adubação potássica, ao nível de 5\% de probabilidade pelo teste $\mathrm{F}$, para o peso do fruto, enquanto que para o comprimento do fruto houve efeito significativo apenas da interação entre lâminas de irrigação e doses de $\mathrm{K}_{2} \mathrm{O}$. Não houve efeito significativo dos tratamentos no diâmetro do fruto.

A Tabela 24 apresenta os valores médios da densidade do suco. Verifica-se uma diferença de $21 \%$ entre o valor mínimo $0,98 \mathrm{~g} \mathrm{~cm}^{-3}$ (combinação $\mathrm{W}_{3} \mathrm{~K}_{1}$ ) e o valor máximo $1,19 \mathrm{~g} \mathrm{~cm}^{-3}$ (combinação $\mathrm{W}_{4} \mathrm{~K}_{3}$ ), diferença essa significativa ao nível de $5 \%$ de probabilidade pelo teste de Tukey. 
Tabela 22. Resumo da análise de variância para as características físicas do maracujazeiro amarelo (densidade do suco, espessura da casca e rendimento de suco)

\begin{tabular}{lcccc}
\hline Causa de Variação & G.L & \multicolumn{3}{c}{ Quadrado Médio (Valor de F) } \\
& \multicolumn{5}{c}{ Dens. suco } & Esp. casca & Rend. suco \\
\hline Blocos (B) & 3 & 0,000666 & 0,226621 & 1,46993 \\
Doses de $\mathrm{K}_{2} \mathrm{O}(\mathrm{K})$ & 4 & $0,007\left(7,74^{*}\right)$ & $10,176\left(46,8^{*}\right)$ & $52,106\left(12,7^{*}\right)$ \\
Resíduo (a) & 12 & 0,000975 & 0,217051 & 4,076167 \\
Parcelas & 19 & & & \\
Lâminas de Irrigação (W) & 3 & $0,0100\left(6,46^{*}\right)$ & $13,56\left(110,6^{*}\right)$ & $69,47\left(20,64^{*}\right)$ \\
Interação K x W & 12 & $0,005\left(3,72^{*}\right)$ & $2,953\left(24,08^{*}\right)$ & $90,402\left(26,8^{*}\right)$ \\
Resíduo (b) & 45 & 0,001557 & 0,122649 & 3,365885 \\
Subparcelas & 79 & & & \\
* significativo ao nível de 5\% de probabilidade pelo teste F. \\
ns não significativo ao nível de 5\% de probabilidade pelo teste F.
\end{tabular}

Tabela 23. Resumo da análise de variância para as características físicas do fruto do maracujazeiro amarelo (peso de fruto, diâmetro e comprimento de fruto).

\begin{tabular}{lcccc}
\hline \multicolumn{1}{c}{ Causa de Variação } & G.L & \multicolumn{3}{c}{ Quadrado Médio (Valor de F) } \\
& & Peso Fruto & Diâm. Fruto & Comp. Fruto \\
\hline Blocos (B) & 3 & 30,54591 & 44,23733 & 11,72319 \\
Doses de $\mathrm{K}_{2} \mathrm{O}(\mathrm{K})$ & 4 & $245,52\left(19,1^{*}\right)$ & $21,381\left(1,19^{\mathrm{ns}}\right)$ & $8,4497\left(0,34^{\mathrm{ns}}\right)$ \\
Resíduo (a) & 12 & 12,8432 & 17,93583 & 24,92151 \\
Parcelas & 19 & & & \\
Lâminas de Irrigação (W) & 3 & $327,362\left(7,60^{*}\right)$ & $28,508\left(2,74^{\mathrm{ns}}\right)$ & $11,266\left(1,06^{\mathrm{ns}}\right)$ \\
Interação K x W & 12 & $407,465\left(9,47^{*}\right)$ & $17,363\left(1,67^{\mathrm{ns}}\right)$ & $41,3849\left(3,9^{*}\right)$ \\
Resíduo (b) & 45 & 43,04709 & & 10,62122 \\
Subparcelas & 79 & & 10,41634 & \\
\hline
\end{tabular}

* significativo ao nível de 5\% de probabilidade pelo teste $\mathrm{F}$.

ns não significativo ao nível de $5 \%$ de probabilidade pelo teste $\mathrm{F}$.

A densidade do suco (média) cresceu segundo uma tendência quadrática, não significativa, em função das doses de $\mathrm{K}_{2} \mathrm{O}$; até o ponto de máximo $\left(0,400 \mathrm{~kg}\right.$ de $\mathrm{K}_{2} \mathrm{O}$ por planta) a taxa média de crescimento foi $0,15 \mathrm{~g} \mathrm{~cm}^{-3}$. Em geral, a densidade do suco ficou dentro dos padrões adequados para a cultura, conforme valores apresentados por Sousa (2000) e Figueiredo et al. (1987). 
Tabela 24. Valores médios da densidade do suco $\left(\mathrm{g} \mathrm{cm}^{-3}\right)$ em frutos de maracujazeiro amarelo.

\begin{tabular}{cccccc}
\hline $\begin{array}{c}\text { Doses de } \mathrm{K}_{2} \mathrm{O} \\
\left(\mathrm{kg} \mathrm{planta}^{-1}\right)\end{array}$ & $63,3\left(\mathrm{~W}_{1}\right)$ & $118,5\left(\mathrm{~W}_{2}\right)$ & $171,5\left(\mathrm{~W}_{3}\right)$ & $220,5\left(\mathrm{~W}_{4}\right)$ & Média \\
\hline $0,00\left(\mathrm{~K}_{0}\right)$ & (A) $1,06 \mathrm{a}$ & $(\mathrm{AB}) 1,04 \mathrm{a}$ & $(\mathrm{B}) 0,98 \mathrm{a}$ & $(\mathrm{A}) 1,08 \mathrm{a}$ & $\mathbf{1 , 0 4}$ \\
$0,200\left(\mathrm{~K}_{1}\right)$ & $(\mathrm{A}) 1,06 \mathrm{a}$ & $(\mathrm{A}) 1,07 \mathrm{a}$ & $(\mathrm{A}) 1,07 \mathrm{a}$ & $(\mathrm{A}) 1,07 \mathrm{a}$ & $\mathbf{1 , 0 7}$ \\
$0,400\left(\mathrm{~K}_{2}\right)$ & (A) $1,09 \mathrm{a}$ & $(\mathrm{A}) 1,05 \mathrm{a}$ & $(\mathrm{A}) 1,05 \mathrm{a}$ & $(\mathrm{B}) 1,19 \mathrm{~b}$ & $\mathbf{1 , 1 0}$ \\
$0,600\left(\mathrm{~K}_{3}\right)$ & (A) $1,09 \mathrm{a}$ & $(\mathrm{A}) 1,07 \mathrm{a}$ & $(\mathrm{A}) 1,12 \mathrm{a}$ & $(\mathrm{A}) 1,08 \mathrm{a}$ & $\mathbf{1 , 0 9}$ \\
$0,800\left(\mathrm{~K}_{4}\right)$ & (A) $1,07 \mathrm{a}$ & $(\mathrm{A}) 1,04 \mathrm{a}$ & $(\mathrm{A}) 1,10 \mathrm{a}$ & $(\mathrm{A}) 1,05 \mathrm{a}$ & $\mathbf{1 , 0 6}$ \\
Média & $\mathbf{1 , 0 7}$ & $\mathbf{1 , 0 5}$ & $\mathbf{1 , 0 6}$ & $\mathbf{1 , 0 9}$ & $\mathbf{1 , 0 7}$ \\
\hline
\end{tabular}

Médias na horizontal seguidas por letras maiúsculas iguais não diferem estatisticamente a $5 \%$ de probabilidade pelo teste de Tukey.

Médias na vertical seguidas por letras minúsculas iguais não diferem estatisticamente a $5 \%$ de probabilidade pelo teste de Tukey.

A Tabela 25 apresenta valores médios da espessura da casca para frutos de maracujá. Os valores alternaram-se de $5,11 \mathrm{~mm}$ (combinação $\mathrm{W}_{2} \mathrm{~K}_{3}$ ) até $8,53 \mathrm{~mm}$ $\left(\mathrm{W}_{2} \mathrm{~K}_{4}\right)$, um acréscimo de $67 \%$, diferença essa significativa ao nível de $5 \%$ de probabilidade pelo teste de Tukey. Em termos médios, a aplicação de doses crescentes de potássio resultou em redução da espessura da casca. A partir de 118,5 mm de lâmina de irrigação também houve tendência de redução na espessura da casca.

Segundo Oliveira et al. (1987) a espessura da casca é importante, porque quanto mais espessa a casca, menor será o rendimento em suco. Nesse experimento, os tratamentos com elevadas doses de $\mathrm{K}_{2} \mathrm{O}$ e níveis de irrigação resultaram em frutos com menor espessura da casca.

Os valores médios de rendimento de suco, apresentados na Tabela 26, indicam que houve diferença significativa a 5\% pelo teste de Tukey. Em média, a aplicação crescente de $\mathrm{K}_{2} \mathrm{O}$ proporcionou uma redução no rendimento de suco de $11,2 \%$ entre a dose $\mathrm{K}_{0}$ e a dose $\mathrm{K}_{3}$, aumentando a partir daí para 39,08\% na dose $\mathrm{K}_{4}$. 
Tabela 25. Valores médios da espessura da casca $(\mathrm{mm})$ de frutos de maracujazeiro amarelo.

\begin{tabular}{cccccc}
\hline Doses de $\mathrm{K}_{2} \mathrm{O}$ & \multicolumn{5}{c}{ Lâminas totais de irrigação $(\mathrm{mm})$} \\
$\left(\mathrm{kg} \mathrm{planta}^{-1}\right)$ & $63,3\left(\mathrm{~W}_{1}\right)$ & $118,5\left(\mathrm{~W}_{2}\right)$ & $171,5\left(\mathrm{~W}_{3}\right)$ & $220,5\left(\mathrm{~W}_{4}\right)$ & Média \\
\hline $0,00\left(\mathrm{~K}_{0}\right)$ & $(\mathrm{A}) 8,41 \mathrm{a}$ & $(\mathrm{BC}) 7,32 \mathrm{a}$ & $(\mathrm{B}) 7,49 \mathrm{ab}$ & $(\mathrm{C}) 6,84 \mathrm{a}$ & $\mathbf{7 , 5 2}$ \\
$0,200\left(\mathrm{~K}_{1}\right)$ & (AB) $7,43 \mathrm{a}$ & (A) $7,66 \mathrm{a}$ & (A) $8,14 \mathrm{a}$ & $(\mathrm{B}) 6,72 \mathrm{ab}$ & $\mathbf{7 , 4 9}$ \\
$0,400\left(\mathrm{~K}_{2}\right)$ & (A) $6,00 \mathrm{~b}$ & (B) $7,75 \mathrm{a}$ & (A) $6,34 \mathrm{c}$ & (AB) $6,87 \mathrm{a}$ & $\mathbf{6 , 7 4}$ \\
$0,600\left(\mathrm{~K}_{3}\right)$ & (A) $5,86 \mathrm{~b}$ & (B) $5,11 \mathrm{~b}$ & (AB) $5,33 \mathrm{~d}$ & (A) $5,97 \mathrm{bc}$ & $\mathbf{5 , 5 7}$ \\
$0,800\left(\mathrm{~K}_{4}\right)$ & (A) $5,47 \mathrm{~b}$ & (B) $8,53 \mathrm{c}$ & (C) $6,93 \mathrm{~b} \mathrm{c}$ & (A) $5,44 \mathrm{c}$ & $\mathbf{6 , 5 9}$ \\
Média & $\mathbf{6 , 6 3}$ & $\mathbf{7 , 2 8}$ & $\mathbf{6 , 8 5}$ & $\mathbf{6 , 3 7}$ & $\mathbf{6 , 7 8}$ \\
\hline
\end{tabular}

Médias na horizontal seguidas por letras maiúsculas iguais não diferem estatisticamente a $5 \%$ de probabilidade pelo teste de Tukey.

Médias na vertical seguidas por letras minúsculas iguais não diferem estatisticamente a $5 \%$ de probabilidade pelo teste de Tukey.

Tabela 26. Valores médios de rendimento de suco de frutos (\%) de maracujazeiro amarelo.

\begin{tabular}{cccccc}
\hline $\begin{array}{c}\text { Doses de } \mathrm{K}_{2} \mathrm{O} \\
\left(\mathrm{kg} \mathrm{planta}^{-1}\right)\end{array}$ & $63,3\left(\mathrm{~W}_{1}\right)$ & $118,5\left(\mathrm{~W}_{2}\right)$ & $171,5\left(\mathrm{~W}_{3}\right)$ & $220,5\left(\mathrm{~W}_{4}\right)$ & Média \\
\hline $0,00\left(\mathrm{~K}_{0}\right)$ & (AB) $36,42 \mathrm{a}$ & (C) $45,01 \mathrm{a}$ & (A) $33,93 \mathrm{a}$ & (B) $39,34 \mathrm{a}$ & $\mathbf{3 8 , 6 8}$ \\
$0,200\left(\mathrm{~K}_{1}\right)$ & (A) $35,05 \mathrm{a}$ & (B) $45,39 \mathrm{a}$ & (C) $30,47 \mathrm{~b}$ & (B) $42,86 \mathrm{~b}$ & $\mathbf{3 8 , 4 4}$ \\
$0,400\left(\mathrm{~K}_{2}\right)$ & (A) $42,14 \mathrm{a}$ & (BC) $34,34 \mathrm{~b}$ & (B) $37,63 \mathrm{c}$ & (C) $32,30 \mathrm{c}$ & $\mathbf{3 6 , 6 0}$ \\
$0,600\left(\mathrm{~K}_{3}\right)$ & (A) $34,71 \mathrm{~b}$ & (A) $33,97 \mathrm{~b}$ & (B) $29,25 \mathrm{~b}$ & (C) $41,15 \mathrm{ab}$ & $\mathbf{3 4 , 7 7}$ \\
$0,800\left(\mathrm{~K}_{4}\right)$ & (A) $34,65 \mathrm{a}$ & (C) $43,14 \mathrm{a}$ & (BC) $40,21 \mathrm{c}$ & (AB) $38,30 \mathrm{c}$ & $\mathbf{3 9 , 0 8}$ \\
Média & $\mathbf{3 6 , 5 9}$ & $\mathbf{4 0 , 3 7}$ & $\mathbf{3 4 , 3 0}$ & $\mathbf{3 8 , 7 9}$ & $\mathbf{3 7 , 5 1}$ \\
\hline
\end{tabular}

Médias na horizontal seguidas por letras maiúsculas iguais não diferem estatisticamente a 5\% de probabilidade pelo teste de Tukey.

Médias na vertical seguidas por letras minúsculas iguais não diferem estatisticamente a $5 \%$ de probabilidade pelo teste de Tukey.

O rendimento de suco em função das lâminas de irrigação não apresentou uma tendência definida, com valores oscilando entre 34,30\% para $\mathrm{W}_{3}$ a $40,37 \%$ para $\mathrm{W}_{2}$. Esses valores são satisfatórios, segundo os relatos de Araújo et al. (1974), que sugerem um bom rendimento de suco entre $30 \%$ e $33 \%$. Figueiredo et al. (1987) afirmam que em 
condições de laboratório o rendimento pode chegar a 40\%, porém, na indústria atinge um valor médio de $24,54 \%$.

Na Tabela 27 estão apresentados os valores médios do peso de fruto, Observa-se que houve diferença significativa entre o peso do fruto mínimo obtido $(136,97 \mathrm{~g}$, na combinação $\left.\mathrm{W}_{2} \mathrm{~K}_{4}\right)$ e o máximo $\left(173,98 \mathrm{~g}\right.$, combinação $\left.\mathrm{W}_{3} \mathrm{~K}_{4}\right)$, ao nível de $5 \%$ de probabilidade pelo teste de Tukey. Na média, a dose intermediária $\mathrm{K}_{3}$ proporcionou maior peso do fruto. Para lâminas de irrigação crescentes, a partir do tratamento $\mathrm{W}_{2}$ (118,5 mm), houve uma tendência de acréscimo contínuo no peso médio do fruto.

Tabela 27. Valores médios do peso de fruto (g) de maracujazeiro amarelo.

\begin{tabular}{cccccc}
\hline $\begin{array}{c}\text { Doses de } \mathrm{K}_{2} \mathrm{O} \\
\left(\mathrm{kg} \mathrm{planta}^{-1}\right)\end{array}$ & $63,3\left(\mathrm{~W}_{1}\right)$ & $118,5\left(\mathrm{~W}_{2}\right)$ & $171,5\left(\mathrm{~W}_{3}\right)$ & $220,5\left(\mathrm{~W}_{4}\right)$ & Média \\
\hline $0,00\left(\mathrm{~K}_{0}\right)$ & $(\mathrm{A}) 149,28 \mathrm{a}$ & $(\mathrm{A}) 149,11 \mathrm{ab}$ & $(\mathrm{A}) 139,97 \mathrm{a}$ & $(\mathrm{A}) 142,56 \mathrm{a}$ & $\mathbf{1 4 5 , 2 3}$ \\
$0,200\left(\mathrm{~K}_{1}\right)$ & $(\mathrm{A}) 151,60 \mathrm{a}$ & $(\mathrm{A}) 147,00 \mathrm{ab}$ & $(\mathrm{A}) 145,46 \mathrm{ab}$ & (B) $162,54 \mathrm{bc}$ & $\mathbf{1 5 1 , 6 5}$ \\
$0,400\left(\mathrm{~K}_{2}\right)$ & (A) $155,62 \mathrm{a}$ & $(\mathrm{A}) 149,05 \mathrm{ab}$ & (A) $139,86 \mathrm{a}$ & (A) $154,25 \mathrm{~b}$ & $\mathbf{1 4 9 , 6 9}$ \\
$0,600\left(\mathrm{~K}_{3}\right)$ & (A) $148,46 \mathrm{a}$ & $(\mathrm{A}) 151,79 \mathrm{a}$ & $(\mathrm{AB}) 158,36 \mathrm{~b}$ & (B) $165,92 \mathrm{c}$ & $\mathbf{1 5 6 , 1 3}$ \\
$0,800\left(\mathrm{~K}_{4}\right)$ & $(\mathrm{A}) 148,05 \mathrm{a}$ & $(\mathrm{B}) 136,97 \mathrm{~b}$ & (C) $173,98 \mathrm{c}$ & (AB) $144,33 \mathrm{a}$ & $\mathbf{1 5 0 , 8 3}$ \\
Média & $\mathbf{1 5 0 , 6 0}$ & $\mathbf{1 4 6 , 7 8}$ & $\mathbf{1 5 1 , 5 3}$ & $\mathbf{1 5 3 , 9 2}$ & $\mathbf{1 5 0 , 7 0}$ \\
\hline
\end{tabular}

Médias na horizontal seguidas por letras maiúsculas iguais não diferem estatisticamente a 5\% de probabilidade pelo teste de Tukey.

Médias na vertical seguidas por letras minúsculas iguais não diferem estatisticamente a 5\% de probabilidade pelo teste de Tukey.

Martins (1998) e Sousa (2000) não encontraram efeito significativo de doses de potássio e lâminas de água sobre o peso médio de frutos. Esses resultados divergem dos obtidos nesse trabalho, em que se constatou o efeito das doses de potássio sobre o peso médio do fruto, concordando com os resultados apresentados por Müller (1977).

Quanto aos efeitos de lâminas de irrigação, Carvalho et al. (2000) obtiveram resposta positiva, concordando com o presente trabalho. No entanto, Sousa (2000) não 
obteve resposta positiva de níveis de irrigação para peso médio do fruto. O mesmo autor afirma que o efeito positivo obtido por outros autores pode ser atribuído às condições climáticas do período de formação dos frutos e diferentes tratamentos com lâminas de irrigação, inclusive ausência de irrigação, favorecendo menor peso médio do fruto.

A Tabela 28 apresenta valores médios de diâmetro do fruto. Não houve diferença significativa entre os tratamentos, ao nível de 5\% de probabilidade pelo teste $\mathrm{F}$ (Tabela 23). $\mathrm{O}$ menor valor $(68,63 \mathrm{~mm})$ foi obtido na combinação $\mathrm{W}_{1} \mathrm{~K}_{4}$ e o maior valor $(76,34$ mm) obtido na combinação $\mathrm{W}_{3} \mathrm{~K}_{4}$. Martins (1998) também não obteve resposta positiva da adubação potássica sobre o diâmetro do fruto.

Tabela 28. Valores médios do diâmetro do fruto $(\mathrm{mm})$ de maracujazeiro amarelo.

\begin{tabular}{cccccc}
\hline $\begin{array}{c}\text { Doses de } \mathrm{K}_{2} \mathrm{O} \\
\left(\mathrm{kg} \mathrm{planta}^{-1}\right)\end{array}$ & $63,3\left(\mathrm{~W}_{1}\right)$ & $118,5\left(\mathrm{~W}_{2}\right)$ & $171,5\left(\mathrm{~W}_{3}\right)$ & $220,5\left(\mathrm{~W}_{4}\right)$ & Média \\
\hline $0,00\left(\mathrm{~K}_{0}\right)$ & 74,11 & 73,35 & 71,16 & 68,63 & $\mathbf{7 1 , 8 1}$ \\
$0,200\left(\mathrm{~K}_{1}\right)$ & 73,46 & 70,16 & 69,49 & 71,48 & $\mathbf{7 1 , 1 5}$ \\
$0,400\left(\mathrm{~K}_{2}\right)$ & 73,55 & 71,62 & 71,76 & 71,33 & $\mathbf{7 2 , 0 6}$ \\
$0,600\left(\mathrm{~K}_{3}\right)$ & 69,16 & 70,73 & 71,89 & 69,17 & $\mathbf{7 0 , 2 4}$ \\
$0,800\left(\mathrm{~K}_{4}\right)$ & 69,97 & 73,07 & 76,34 & 74,05 & $\mathbf{7 3 , 3 6}$ \\
Média & $\mathbf{7 2 , 0 5}$ & $\mathbf{7 1 , 7 9}$ & $\mathbf{7 2 , 1 3}$ & $\mathbf{7 0 , 9 3}$ & $\mathbf{7 1 , 7 2}$ \\
\hline
\end{tabular}

Os valores de diâmetro obtidos nesse trabalho caracterizam os frutos como de tamanho grande, fato importante para seleção de frutos e comercialização in natura.

Na literatura o valor de diâmetro do fruto é variável: 62,4 mm (Figueiredo et al., 1987), 68,3 mm (Nascimento, 1996), 58,8 mm (Sjostrom \& Rosa, 1978) e $83 \mathrm{~mm}$ (Martins, 1998).

Os valores médios do comprimento do fruto estão apresentados na Tabela 29. Nota-se que o máximo comprimento $81,91 \mathrm{~mm}$ (combinação $\mathrm{W}_{4} \mathrm{~K}_{2}$ ) foi $11 \%$ superior ao 
valor mínimo $73,87 \mathrm{~mm}$ (combinação $\mathrm{W}_{3} \mathrm{~K}_{2}$ ), diferindo-se ao nível de $5 \%$ de probabilidade pelo teste de Tukey.

Tabela 29. Valores médios de comprimento do fruto $(\mathrm{mm})$ de maracujazeiro amarelo.

\begin{tabular}{cccccc}
\hline $\begin{array}{c}\text { Doses de } \mathrm{K}_{2} \mathrm{O} \\
\left(\mathrm{kg} \mathrm{planta}^{-1}\right)\end{array}$ & $63,3\left(\mathrm{~W}_{1}\right)$ & $118,5\left(\mathrm{~W}_{2}\right)$ & $171,5\left(\mathrm{~W}_{3}\right)$ & $220,5\left(\mathrm{~W}_{4}\right)$ & Média \\
\hline $0,00\left(\mathrm{~K}_{0}\right)$ & (A) $79,08 \mathrm{a}$ & (A) $80,45 \mathrm{a}$ & (A) $77,84 \mathrm{a}$ & $(\mathrm{A}) 76,28 \mathrm{ab}$ & $\mathbf{7 8 , 4 1}$ \\
$0,200\left(\mathrm{~K}_{1}\right)$ & $(\mathrm{AB}) 79,43 \mathrm{a}$ & (A) $75,63 \mathrm{a}$ & (A) $73,87 \mathrm{a}$ & (B) $81,91 \mathrm{~b}$ & $\mathbf{7 7 , 7 1}$ \\
$0,400\left(\mathrm{~K}_{2}\right)$ & (A) $81,14 \mathrm{a}$ & (A) $77,40 \mathrm{a}$ & (A) $75,26 \mathrm{a}$ & (A) $76,38 \mathrm{ab}$ & $\mathbf{7 7 , 5 5}$ \\
$0,600\left(\mathrm{~K}_{3}\right)$ & (A) $79,40 \mathrm{a}$ & (AB) $76,86 \mathrm{a}$ & (A) $79,42 \mathrm{a}$ & (B) $71,62^{\mathrm{a}}$ & $\mathbf{7 6 , 8 3}$ \\
$0,800\left(\mathrm{~K}_{4}\right)$ & (A) $76,51 \mathrm{a}$ & (A) $75,71 \mathrm{a}$ & (A) $81,56 \mathrm{a}$ & (A) $80,82 \mathrm{ab}$ & $\mathbf{7 8 , 6 5}$ \\
Média & $\mathbf{7 9 , 1 1}$ & $\mathbf{7 7 , 2 1}$ & $\mathbf{7 7 , 5 9}$ & $\mathbf{7 7 , 4 0}$ & $\mathbf{7 7 , 8 3}$ \\
\hline
\end{tabular}

Médias na horizontal seguidas por letras maiúsculas iguais não diferem estatisticamente a $5 \%$ de probabilidade pelo teste de Tukey.

Médias na vertical seguidas por letras minúsculas iguais não diferem estatisticamente a $5 \%$ de probabilidade pelo teste de Tukey.

Entre os tratamentos $\mathrm{K}_{0}$ e $\mathrm{K}_{3}$ as doses de $\mathrm{K}_{2} \mathrm{O}$ promoveram uma redução no comprimento médio do fruto, aumentando em seguida, no tratamento $\mathrm{K}_{4}$. Para a aplicação crescente de lâminas de água, os valores de comprimento médio de fruto reduziram de 79,11 $\mathrm{mm}\left(\mathrm{W}_{1}\right)$ para 77,21 $\mathrm{mm}\left(\mathrm{W}_{2}\right)$, mantendo-se praticamente constante a partir dessa lâmina de água.

Martins (1998), avaliando o efeito da adubação potássica e das lâminas de irrigação não verificou efeito da interação desses fatores no comprimento do fruto de maracujá amarelo, semelhantemente aos resultados encontrados por Sousa (2000), ambos na primeira fase de produção da cultura, divergindo dos resultados desse trabalho que apresentou resposta positiva à interação $\mathrm{K}_{2} \mathrm{O}$ e lâminas de irrigação para comprimento do fruto no seu segundo ano de produção. 


\subsection{Estado Nutricional}

O estado nutricional das plantas é importante para o manejo da cultura, principalmente quando se faz uso da fertirrigação. A aplicação freqüente de nutrientes na zona radicular das plantas pode ocasionar prejuízos na produção devido a um excesso ou falta de nutrientes. Assim, a parte da planta que melhor representa seu estado nutricional são as folhas, onde ocorrem a maioria dos processos fisiológicos, sendo essas utilizadas para a avaliação nutricional (Malavolta et al., 1989; Raij, 1991 e Malavolta, 1994).

Neste trabalho foram avaliadas as concentrações foliares dos seguintes macronutrientes: nitrogênio $(\mathrm{N})$, fósforo $(\mathrm{P})$, potássio $(\mathrm{K})$, cálcio $(\mathrm{Ca})$, magnésio $(\mathrm{Mg})$ e enxofre $(S)$. Foram também determinadas as concentrações foliares dos micronutrientes boro $(\mathrm{B})$, cobre $(\mathrm{Cu})$, ferro $(\mathrm{Fe})$, manganês $(\mathrm{Mn})$ e zinco $(\mathrm{Zn})$.

\subsubsection{Concentrações foliares de macronutrientes}

Quanto às concentrações de macronutrientes nas folhas, os tratamentos com diferentes doses de $\mathrm{K}_{2} \mathrm{O}$ tiveram efeito significativo nas concentrações foliares de potássio e magnésio. Nos demais macronutrientes não houve efeito significativo ao nível de $5 \%$ de probabilidade pelo teste $\mathrm{F}$ (Tabelas 30 e 31 ).

A maior concentração de nitrogênio nas folhas de maracujá foi obtida com o tratamento $\mathrm{W}_{4} \mathrm{~K}_{1}\left(73,92 \mathrm{~g} \cdot \mathrm{kg}^{-1}\right)$ e a menor concentração com o tratamento $\mathrm{W}_{1} \mathrm{~K}_{2}(40,88$ g. $\mathrm{kg}^{-1}$ ). No entanto, as concentrações de $\mathrm{N}$ apresentaram baixa variação (Figura 6). 
Tabela 30. Resumo da análise de variância para concentração de macronutrientes $(\mathrm{N}, \mathrm{P}$ e K).

\begin{tabular}{|c|c|c|c|c|}
\hline \multirow[t]{2}{*}{ Causa de Variação } & \multirow[t]{2}{*}{ G.L } & \multicolumn{3}{|c|}{ Estatística F } \\
\hline & & $\mathrm{N}$ & $\mathrm{P}$ & K \\
\hline Blocos (B) & 3 & & & \\
\hline Doses de $\mathrm{K}_{2} \mathrm{O}(\mathrm{K})$ & 4 & $0,61^{\mathrm{ns}}$ & $1,28^{\mathrm{ns}}$ & $5,04^{*}$ \\
\hline Resíduo (a) & 12 & & & \\
\hline Parcelas & 19 & & & \\
\hline Lâminas de Irrigação (W) & 3 & $0,63^{\mathrm{ns}}$ & $1,37^{\mathrm{ns}}$ & $13,32^{*}$ \\
\hline Interação K x W & 12 & $0,91^{\mathrm{ns}}$ & $0,52^{\mathrm{ns}}$ & $1,58^{\mathrm{ns}}$ \\
\hline Resíduo (b) & 45 & & & \\
\hline Subparcelas & 79 & & & \\
\hline
\end{tabular}

Tabela 31. Resumo da análise de variância para concentração de macronutrientes (Ca, Mg e S).

\begin{tabular}{lcccc}
\hline Causa de Variação & G.L & \multicolumn{2}{c}{ Estatística F } \\
& & Ca & Mg & S \\
\hline Blocos (B) & 3 & & & \\
Doses de K $2 \mathrm{O}(\mathrm{K})$ & 4 & $0,96^{\mathrm{ns}}$ & $4,31^{*}$ & $0,50^{\mathrm{ns}}$ \\
Resíduo (a) & 12 & & & \\
Parcelas & 19 & & & \\
Lâminas de Irrigação (W) & 3 & $1,29^{\mathrm{ns}}$ & $12,06^{*}$ & $1,43^{\mathrm{ns}}$ \\
Interação K x W & 12 & $1,03^{\mathrm{ns}}$ & $0,90^{\mathrm{ns}}$ & $1,81^{\mathrm{ns}}$ \\
Resíduo (b) & 45 & & & \\
Subparcelas & 79 & & & \\
\hline
\end{tabular}

* significativo ao nível de 5\% de probabilidade pelo teste $\mathrm{F}$.

ns não significativo ao nível de $5 \%$ de probabilidade pelo teste $\mathrm{F}$. 


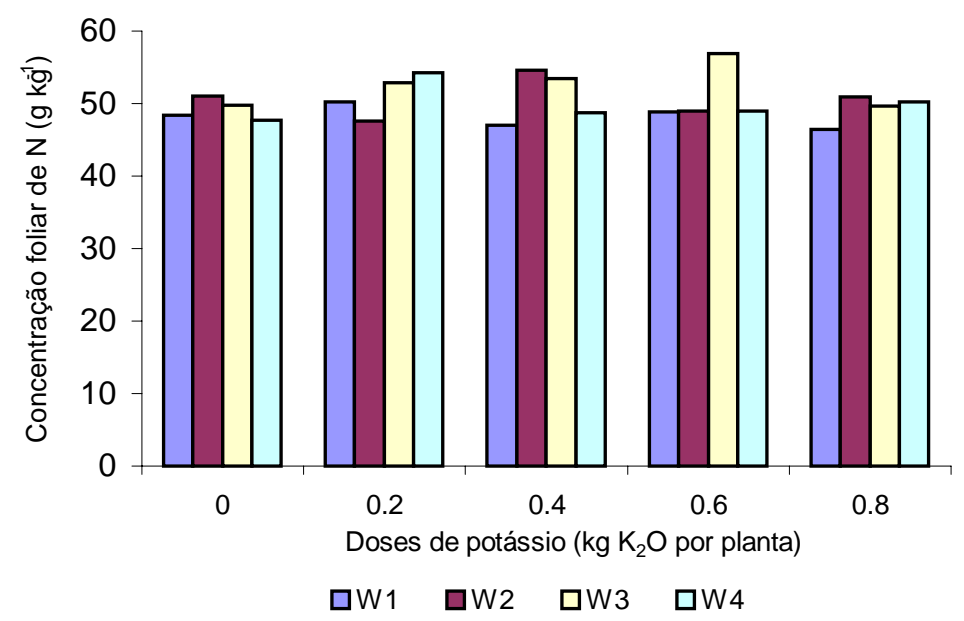

Figura 6 - Efeito de doses de potássio e lâminas de irrigação na concentração de nitrogênio nas folhas de maracujazeiro amarelo.

De acordo com Rodriguez (1982), as ações do potássio e do nitrogênio se complementam nas plantas, devendo manter um certo equilíbrio. Esse fato é destacado por Ruggiero et al. (1996) que salientam a importância do potássio na participação do metabolismo nitrogenado, afetando diversas fases da utilização do nitrogênio pelas plantas.

A concentração de $\mathrm{P}$ nas folhas não foi afetada pelos tratamentos, como também não se observou uma tendência no comportamento desse nutriente quanto as doses de $\mathrm{K}_{2} \mathrm{O}$ e níveis de irrigação (Figura 7). A maior concentração de $\mathrm{P}$ observada nas folhas de maracujá foi obtida com o tratamento $\mathrm{W}_{2} \mathrm{~K}_{0}\left(3,26 \mathrm{~g} \cdot \mathrm{kg}^{-1}\right)$ e a menor concentração com o tratamento $\mathrm{W}_{3} \mathrm{~K}_{0}\left(1,03 \mathrm{~g} \cdot \mathrm{kg}^{-1}\right)$. 


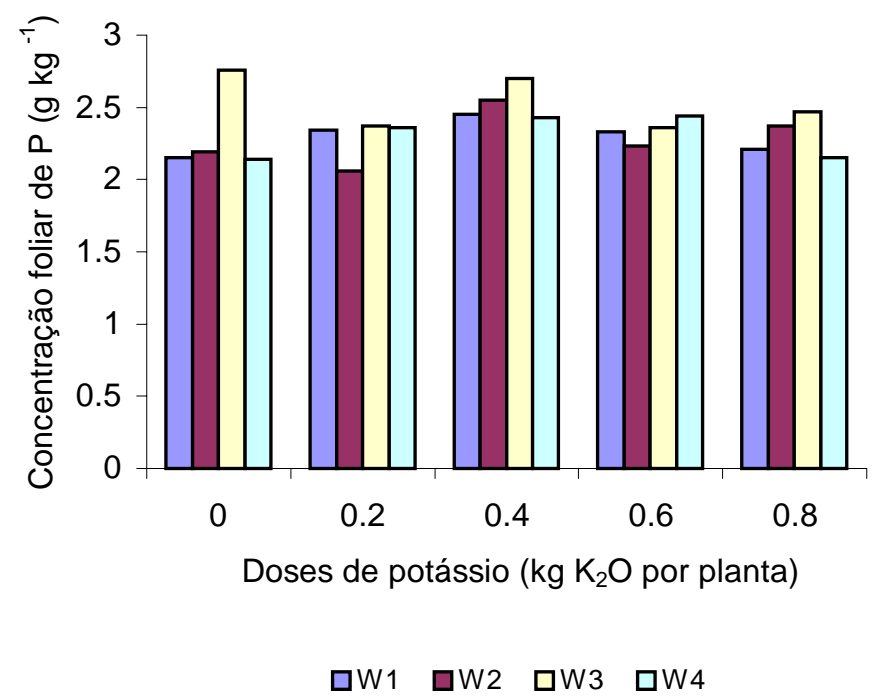

Figura 7 - Efeito de doses de potássio e lâminas de irrigação na concentração de fósforo nas folhas do maracujazeiro amarelo.

As concentrações de $\mathrm{P}$ nas folhas do maracujazeiro amarelo ficaram acima do valor mínimo encontrado na literatura, de 1,8 g. $\mathrm{kg}^{-1}$ (Baumgartener et al., 1978; Primavesi \& Malavolta, 1980 a; Menzel et al., 1986 e Colauto et al.,1986).

A concentração foliar de potássio foi significativamente influenciada pelas doses de $\mathrm{K}_{2} \mathrm{O}$ aplicadas via fertirrigação, sendo a menor concentração obtida no tratamento $\mathrm{W}_{4} \mathrm{~K}_{0}\left(12,81 \mathrm{~g} \cdot \mathrm{kg}^{-1}\right)$ enquanto que a maior foi obtida no tratamento $\mathrm{W}_{3} \mathrm{~K}_{4}\left(27,92 \mathrm{~g} \cdot \mathrm{kg}^{-1}\right)$. Na Figura 8 observa-se que houve variação na concentração foliar de $\mathrm{K}^{+}$com a aplicação de doses crescentes de $\mathrm{K}_{2} \mathrm{O}$. 


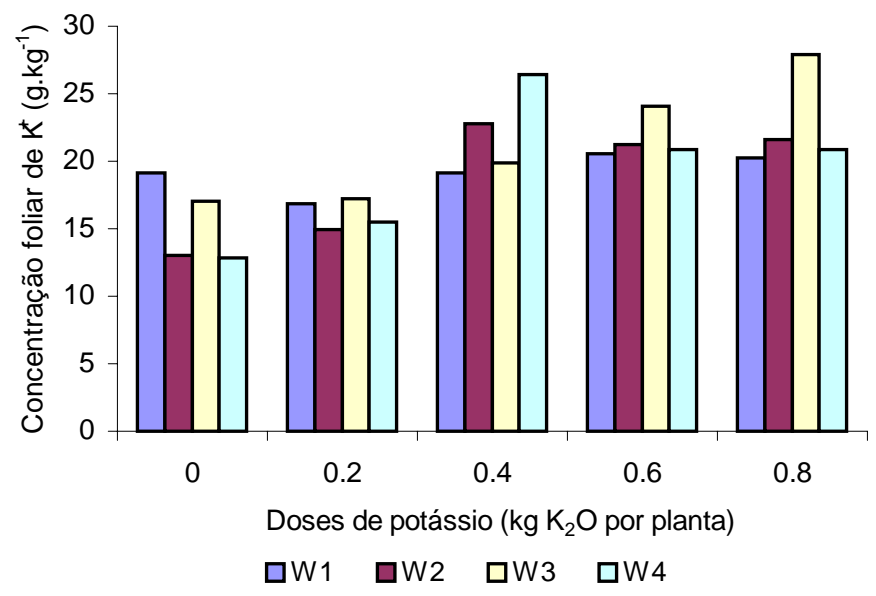

Figura 8 - Efeito de doses de potássio e lâminas de irrigação na concentração de potássio nas folhas do maracujazeiro amarelo.

Nos tratamentos sem adição de potássio $\left(\mathrm{K}_{0}\right)$ não foram constatados os menores valores de concentração de $\mathrm{K}^{+}$como observado por Sousa (2000), no primeiro ano desse experimento.

A concentração de cálcio nas folhas de maracujazeiro amarelo não sofreu influência das doses de $\mathrm{K}_{2} \mathrm{O}$ associadas com níveis de irrigação, verificando-se que não houve uma inibição competitiva que pode ocorrer entre esses dois nutrientes (Malavolta, 1980). Entretanto esse resultado não concorda com os resultados obtidos por Sousa (2000), que encontrou efeito de doses de potássio na concentração de Ca nas folhas.

Na Figura 9 observa-se que a maior concentração de Ca nas folhas foi obtida no tratamento $\mathrm{W}_{1} \mathrm{~K}_{0}\left(50,10 \mathrm{~g} \cdot \mathrm{kg}^{-1}\right)$ e a menor no tratamento $\mathrm{W}_{1} \mathrm{~K}_{1}\left(13,7 \mathrm{~g} \cdot \mathrm{kg}^{-1}\right)$. 


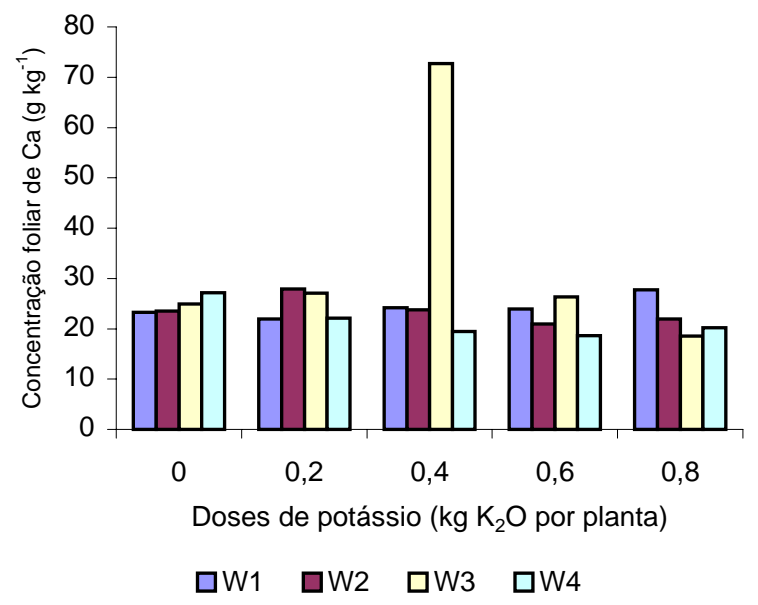

Figura 9 - Efeito de doses de potássio e lâminas de irrigação na concentração de cálcio nas folhas do maracujazeiro amarelo.

O Mg é um nutriente que pode sofrer competição com o potássio, porém nesse experimento houve um equilíbrio entre esses nutrientes, não ocorrendo essa competição.

A concentração de $\mathrm{Mg}$ nas folhas de maracujá sofreu influência das doses de $\mathrm{K}_{2} \mathrm{O}$ e lâminas de irrigação (Tabela 31). A maior concentração foi obtida com o tratamento $\mathrm{W}_{4} \mathrm{~K}_{0}\left(7,21 \mathrm{~g} \cdot \mathrm{kg}^{-1}\right)$ e a menor concentração com o tratamento $\mathrm{W}_{4} \mathrm{~K}_{2}\left(3,95 \mathrm{~g} \cdot \mathrm{kg}^{-1}\right)$, porém as maiores concentrações de $\mathrm{Mg}$ nas folhas foram observadas nos tratamentos $\mathrm{K}_{0}$ e $\mathrm{K}_{1}$ (Figura 10), o que está de acordo com os resultados obtidos por Sousa (2000). 


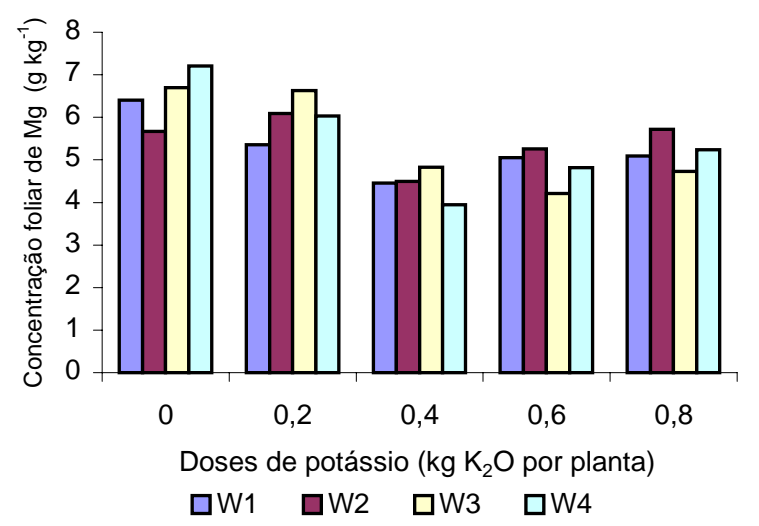

Figura 10 - Efeito de doses de potássio e lâminas de irrigação na concentração de magnésio nas folhas do maracujazeiro amarelo.

O enxofre é um nutriente pouco estudado e, em geral, sua necessidade é suprida quando se faz uso de adubação com sulfato. A concentração desse nutriente nas folhas do maracujazeiro não variou muito (Figura 11). A maior concentração foi obtida com o tratamento $\mathrm{W}_{1} \mathrm{~K}_{0}\left(5,77 \mathrm{~g} \cdot \mathrm{kg}^{-1}\right)$ e a menor com o tratamento $\mathrm{W}_{2} \mathrm{~K}_{0}\left(4,27 \mathrm{~g} \cdot \mathrm{kg}^{-1}\right)$.

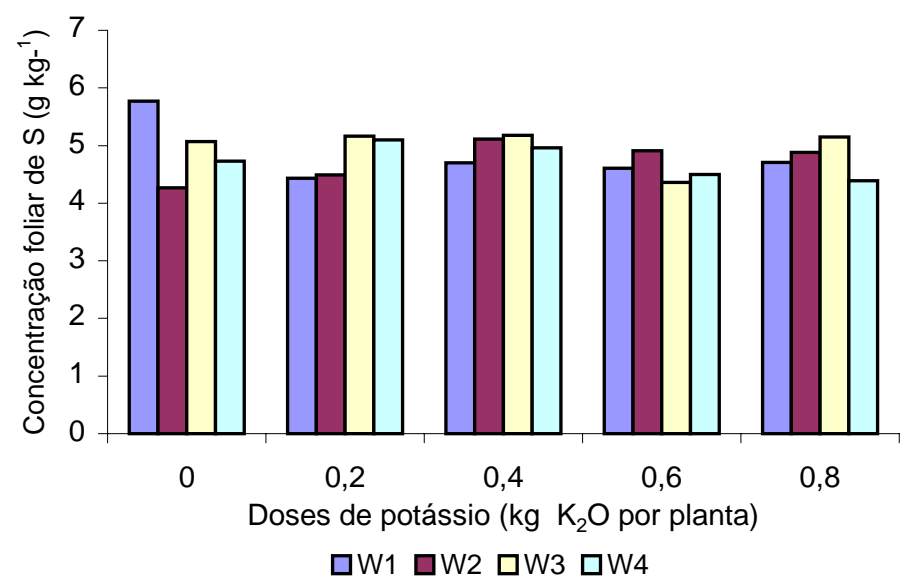

Figura 11 - Efeito de doses de potássio e lâminas de irrigação na concentração de enxofre nas folhas do maracujazeiro amarelo. 


\subsubsection{Concentrações foliares de micronutrientes}

A Tabela 32 apresenta o resumo da análise de variância para as concentrações foliares de boro, cobre e ferro. As concentrações foliares de boro foram influenciadas significativamente pela interação entre doses de potássio e lâminas de irrigação. Um dos fatores que pode ocasionar a deficiência desse elemento é o déficit hídrico (Malavolta, 1980; Raij, 1991) e a disponibilidade hídrica adequada favorece a absorção desse elemento como constatado por Menzel et al.(1986). No entanto, os valores máximos e mínimos encontrados, 25,60 mg. $\mathrm{kg}^{-1}$ e $10,45 \mathrm{mg} \cdot \mathrm{kg}^{-1}$, respectivamente (Figura 12), estão abaixo da faixa de valores médios ideais considerados para a cultura do maracujazeiro, de 39 mg. $\mathrm{kg}^{-1}$ a $47 \mathrm{mg} \cdot \mathrm{kg}^{-1}$ (Haag, 1973). Kliemann et al. (1986) afirmam que o boro é um nutriente cuja concentração em plantas de maracujazeiro amarelo é, em média, superior a maioria dos vegetais.

Tabela 32. Resumo da análise de variância para concentração de micronutrientes $(\mathrm{B}, \mathrm{Cu}$ e $\mathrm{Fe})$.

\begin{tabular}{lcccc}
\hline Causa de Variação & G.L & \multicolumn{2}{c}{ Estatística F } \\
& & B & Cu & Fe \\
\hline Blocos (B) & 3 & & & \\
Doses de K $2 \mathrm{O}(\mathrm{K})$ & 4 & $1,00^{\mathrm{ns}}$ & $0,47^{\mathrm{ns}}$ & $0,45^{\mathrm{ns}}$ \\
Resíduo (a) & 12 & & & \\
Parcelas & 19 & & & \\
Lâminas de Irrigação (W) & 3 & $1,89^{\mathrm{ns}}$ & $1,15^{\mathrm{ns}}$ & $0,69^{\mathrm{ns}}$ \\
Interação K x W & 12 & $2,32^{*}$ & $1,10^{\mathrm{ns}}$ & $2,54^{*}$ \\
resíduo (b) & 45 & & & \\
Subparcelas & 79 & & \\
* significativo ao nível de 5\% de probabilidade pelo teste F. & \\
ns não significativo ao nível de 5\% de probabilidade pelo teste F. &
\end{tabular}




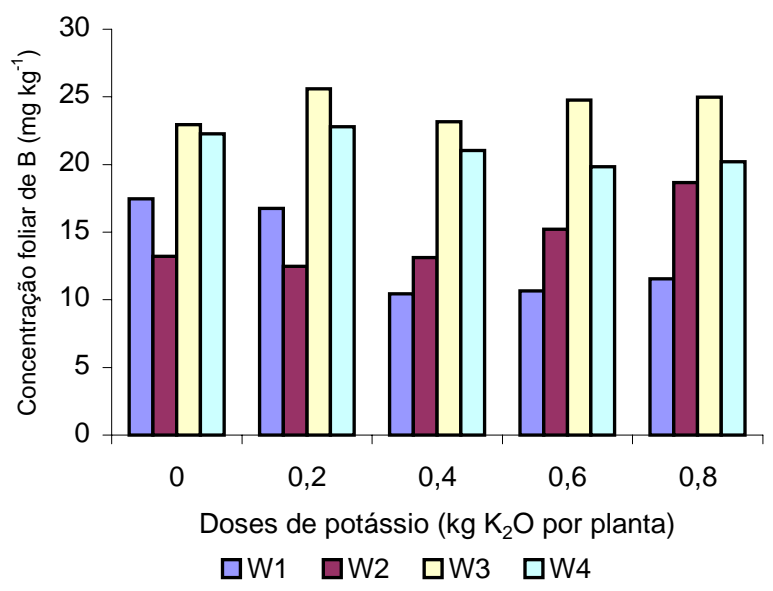

Figura 12 - Efeito de doses de potássio e lâminas de irrigação na concentração de boro nas folhas do maracujazeiro amarelo.

A concentração de cobre presente nas folhas de maracujá não sofreu efeito dos tratamentos testados. Para as lâminas de irrigação $W_{1}$ e $W_{2}$ observou-se as menores concentrações de cobre nas folhas com o aumento das doses de potássio (Figura 13). A lâmina $\mathrm{W}_{3}$ apresentou as maiores concentrações de cobre com maiores doses de $\mathrm{K}_{2} \mathrm{O}$ e a lâmina $\mathrm{W}_{4}$ teve as maiores concentrações de cobre com as menores doses de $\mathrm{K}_{2} \mathrm{O}$.

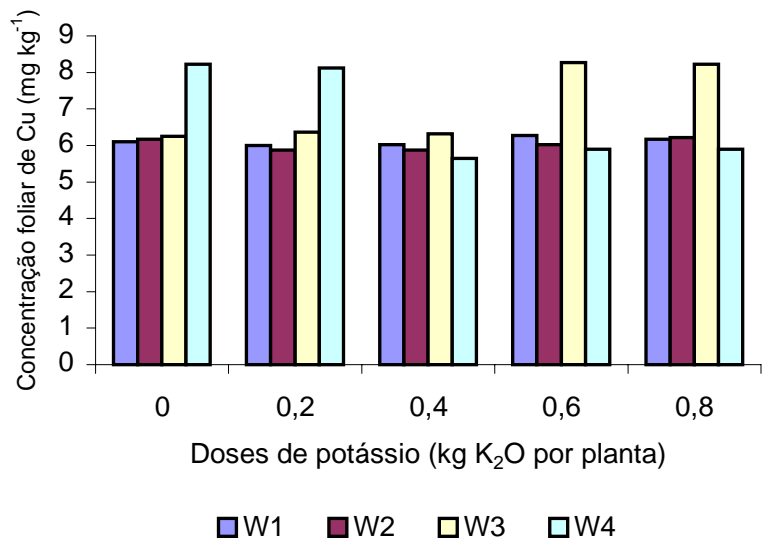

Figura 13 - Efeito de doses de potássio e lâminas de irrigação na concentração de cobre nas folhas do maracujazeiro amarelo. 
A maior concentração foliar de cobre foi de $8,27 \mathrm{mg} \cdot \mathrm{kg}^{-1}$ e a menor igual a 5,87 mg. $\mathrm{kg}^{-1}$. Esses valores estão abaixo do valor encontrado por Sousa (2000) e outros autores como Haag (1973), Malavolta et al. (1989), Primavesi \& Malavolta (1980) e Menzel (1986). No entanto, apesar de ser absorvido em pequena quantidade pela planta, o cobre pode ocasionar danos ao crescimento da planta (Haag, 1973).

Para a concentração de ferro nas folhas observou-se efeito da interação entre doses de $\mathrm{K}_{2} \mathrm{O}$ e níveis de irrigação (Tabela 32). A menor concentração foliar média de ferro foi de 129,45 mg. $\mathrm{kg}^{-1}$ e a maior de $201,30 \mathrm{mg} \cdot \mathrm{kg}^{-1}$ (Figura 14). Esses valores estão de acordo aqueles considerados adequados para cultura do maracujazeiro, apresentados por Malavolta et al. (1989).

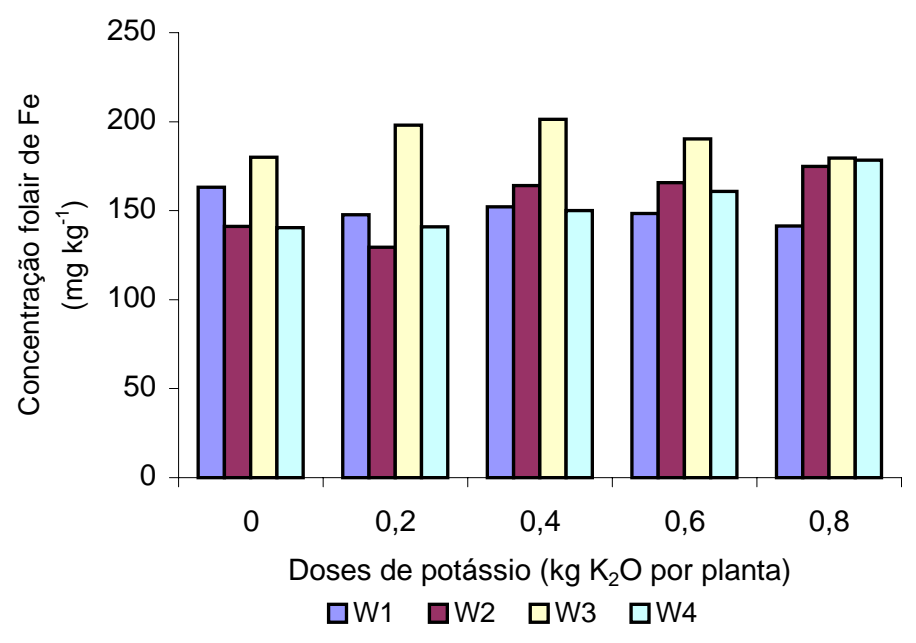

Figura 14 - Efeito de doses de potássio e lâminas de irrigação na concentração de ferro nas folhas do maracujazeiro amarelo.

A Tabela 33 apresenta o resumo da análise de variância para as concentrações foliares de manganês e zinco. As doses de $\mathrm{K}_{2} \mathrm{O}$ influenciaram significativamente as concentrações de manganês nas folhas do maracujazeiro amarelo, enquanto que os 
níveis de irrigação não tiveram influência sobre esse elemento, concordando com os resultados obtidos por Sousa (2000). Porém, as concentrações máximas e mínimas obtidas nesse trabalho (171,60 mg. $\mathrm{kg}^{-1}$ e $375,95 \mathrm{mg} \cdot \mathrm{kg}^{-1}$, Figura 15) foram maiores do que aquelas obtidas por Sousa (2000), com valor mínimo de $133,15 \mathrm{mg} \cdot \mathrm{kg}^{-1}$ e máximo de $239,63 \mathrm{mg} \cdot \mathrm{kg}^{-1}$.

Tabela 33. Resumo da análise de variância para concentração de micronutrientes (Mn e $\mathrm{Zn})$.

\begin{tabular}{lccc}
\hline Causa de Variação & G.L & Mn & Estatística F \\
& & & \\
\hline Blocos (B) & 3 & $9,40^{*}$ & $0,45^{\mathrm{ns}}$ \\
Doses de $\mathrm{K}_{2} \mathrm{O}(\mathrm{K})$ & 4 & & \\
Resíduo (a) & 12 & & \\
Parcelas & 19 & $7,87^{*}$ & $1,39^{\mathrm{ns}}$ \\
Lâminas de Irrigação (W) & 3 & $1,22^{\mathrm{ns}}$ & $0,70^{\mathrm{ns}}$ \\
Interação K x W & 12 & & \\
resíduo (b) & 45 & & \\
Subparcelas & 79 & & \\
\hline
\end{tabular}

* significativo ao nível de 5\% de probabilidade pelo teste $\mathrm{F}$.

ns não significativo ao nível de 5\% de probabilidade pelo teste F.

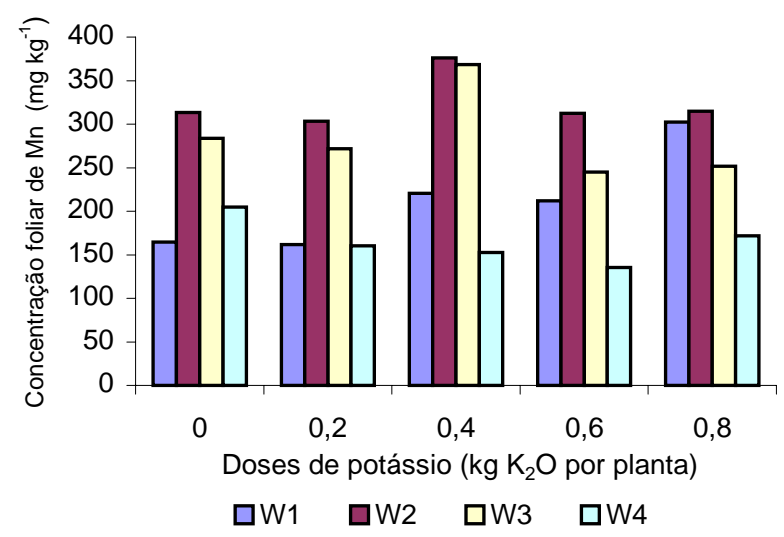

Figura 15 - Efeito de doses de potássio e lâminas de irrigação na concentração de manganês nas folhas do maracujazeiro amarelo. 
As concentrações de zinco nas folhas não foram influenciadas pelas doses de $\mathrm{K}_{2} \mathrm{O}$ e níveis de irrigação aplicados por gotejamento. As concentrações máximas e mínimas obtidas foram, respectivamente, 30,15 mg.kg ${ }^{-1}$ e 22,15 mg.kg ${ }^{-1}$ (Figura 16). Esses valores foram superiores aos obtidos por Sousa (2000), iguais a 24,10 mg.kg-1 e $19,27 \mathrm{mg} \cdot \mathrm{kg}^{-1}$

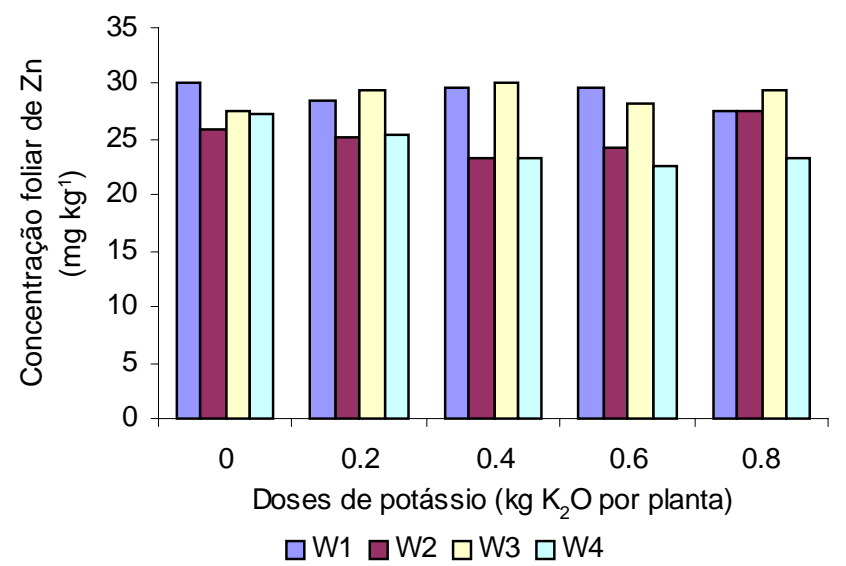

Figura 16 - Efeito de doses de potássio e lâminas de irrigação na concentração de zinco nas folhas do maracujazeiro amarelo.

\subsection{Classificação de frutos}

A classificação de frutos é de grande importância, pois possibilita a comercialização de frutos padronizados (tamanho, peso, coloração) alcançando melhores preços. Para o consumo in natura, os frutos maiores e com boa aparência são os mais visados pelos consumidores. Segundo Tocchini et al. (1995) as indústrias brasileiras ainda não dispõem de uma tecnologia de controle de qualidade de frutos de maracujá, que seja bem difundida e definida, resultando em um rendimento no processamento de frutos relativamente baixo, que varia entre 28 e $35 \%$. 
Em geral os frutos produzidos com o uso de fertirrigação apresentaram uma boa distribuição entre as classes estabelecidas por Meletti \& Maia (1999), com boas características tanto para o consumo in natura como para a industrialização.

A Tabela 34 apresenta a classificação dos frutos de maracujazeiro amarelo colhidos no período de dezembro/2000 a fevereiro/2001, de acordo com a classificação estabelecida por Meletti \& Maia (1999) e utilizada pelo CEAGESP/SP para comercialização dos frutos.

Tabela 34. Classificação dos frutos comerciais colhidos.

\begin{tabular}{cccccc}
\hline & \multicolumn{5}{c}{ Classificação de frutos comerciais por tipo $\left.\left(\mathrm{kg}^{-1}\right)^{-1}\right)$} \\
Tratamentos & Especial & Extra & Extra A & Extra AA & Extra AAA \\
\hline $\mathrm{W}_{1} \mathrm{~K}_{0}$ & 76,48 & 113,93 & 391,21 & 662,16 & 892,50 \\
$\mathrm{~W}_{2} \mathrm{~K}_{0}$ & 134,46 & 172,06 & 1385,30 & 2479,88 & 2088,97 \\
$\mathrm{~W}_{3} \mathrm{~K}_{0}$ & 146,99 & 603,55 & 4100,60 & 3983,59 & 1419,17 \\
$\mathrm{~W}_{4} \mathrm{~K}_{0}$ & 167,68 & 230,20 & 1003,91 & 736,58 & 721,60 \\
$\mathrm{~W}_{1} \mathrm{~K}_{1}$ & 31,54 & 146,53 & 493,25 & 626,80 & 890,49 \\
$\mathrm{~W}_{2} \mathrm{~K}_{1}$ & 254,69 & 461,59 & 1746,68 & 1458,14 & 1270,66 \\
$\mathrm{~W}_{3} \mathrm{~K}_{1}$ & 334,05 & 656,83 & 2795,53 & 2620,81 & 2779,25 \\
$\mathrm{~W}_{4} \mathrm{~K}_{1}$ & 71,38 & 213,34 & 790,91 & 1186,57 & 1070,18 \\
$\mathrm{~W}_{1} \mathrm{~K}_{2}$ & 131,86 & 146,62 & 520,67 & 444,11 & 813,05 \\
$\mathrm{~W}_{2} \mathrm{~K}_{2}$ & 134,99 & 176,91 & 550,16 & 1636,09 & 804,33 \\
$\mathrm{~W}_{3} \mathrm{~K}_{2}$ & 134,82 & 396,66 & 1247,05 & 1473,35 & 1345,54 \\
$\mathrm{~W}_{4} \mathrm{~K}_{2}$ & 315,25 & 729,12 & 2317,85 & 2323,81 & 3398,69 \\
$\mathrm{~W}_{1} \mathrm{~K}_{3}$ & 149,02 & 316,63 & 661,77 & 615,69 & 644,75 \\
$\mathrm{~W}_{2} \mathrm{~K}_{3}$ & 83,43 & 168,80 & 497,95 & 280,16 & 418,55 \\
$\mathrm{~W}_{3} \mathrm{~K}_{3}$ & 53,32 & 68,69 & 268,82 & 465,28 & 734,30 \\
$\mathrm{~W}_{4} \mathrm{~K}_{3}$ & 77,95 & 72,13 & 394,76 & 170,77 & 429,87 \\
$\mathrm{~W}_{1} \mathrm{~K}_{4}$ & 42,52 & 37,96 & 926,86 & 1294,51 & 626,06 \\
$\mathrm{~W}_{2} \mathrm{~K}_{4}$ & 114,00 & 137,58 & 1511,33 & 1300,31 & 3643,86 \\
$\mathrm{~W}_{3} \mathrm{~K}_{4}$ & 94,27 & 176,60 & 505,90 & 777,61 & 3192,12 \\
$\mathrm{~W}_{4} \mathrm{~K}_{4}$ & 53,33 & 32,97 & 90,49 & 170,70 & 675,76 \\
\hline
\end{tabular}




\subsection{Produtividade}

A Tabela 35 mostra a produtividade comercial obtida mensalmente durante o período de colheita. Ocorreram dois picos de produção: em fevereiro de 2001 e em abril/maio de 2001, com as maiores produções concentrando-se em abril. Isso pode ter ocorrido devido a poda efetuada aos 500 dias após o transplantio, causando um florescimento desuniforme e, conseqüentemente, uma desuniformidade na produção. Os tratamentos $\mathrm{W}_{1} \mathrm{~K}_{1}, \mathrm{~W}_{1} \mathrm{~K}_{2}, \mathrm{~W}_{2} \mathrm{~K}_{3}, \mathrm{~W}_{3} \mathrm{~K}_{3}$ e $\mathrm{W}_{1} \mathrm{~K}_{4}$ não produziram frutos no mês de dezembro, enquanto que no mês de março a produção foi em geral, baixa.

Tabela 35. Distribuição mensal da produtividade comercial $\left(\mathrm{kg} \cdot \mathrm{ha}^{-1}\right)$ do maracujazeiro durante o período de colheita.

\begin{tabular}{ccccccc}
\hline & \multicolumn{5}{c}{ meses } \\
Tratamentos & dezembro & janeiro & fevereiro & março & abril & maio \\
\hline $\mathrm{W}_{1} \mathrm{~K}_{0}$ & 152,75 & 1665,23 & 3266,54 & 257,99 & 20,52 & 4662,54 \\
$\mathrm{~W}_{2} \mathrm{~K}_{0}$ & 1186,83 & 3442,50 & 5523,82 & 360,08 & 2959,00 & 2485,93 \\
$\mathrm{~W}_{3} \mathrm{~K}_{0}$ & 2438,93 & 4937,97 & 3997,89 & 346,89 & 2966,93 & 5170,82 \\
$\mathrm{~W}_{4} \mathrm{~K}_{0}$ & 199,50 & 3537,51 & 2486,71 & 33,28 & 1998,18 & 1803,82 \\
$\mathrm{~W}_{1} \mathrm{~K}_{1}$ & 0,00 & 2703,39 & 1180,21 & 155,93 & 2953,96 & 1645,32 \\
$\mathrm{~W}_{2} \mathrm{~K}_{1}$ & 40,35 & 2509,55 & 2216,86 & 208,46 & 2637,29 & 3535,04 \\
$\mathrm{~W}_{3} \mathrm{~K}_{1}$ & 343,93 & 3094,59 & 4662,61 & 45,98 & 3268,25 & 3375,00 \\
$\mathrm{~W}_{4} \mathrm{~K}_{1}$ & 67,61 & 3320,71 & 4643,13 & 613,16 & 1789,29 & 2706,82 \\
$\mathrm{~W}_{1} \mathrm{~K}_{2}$ & 0,00 & 3845,11 & 1603,71 & 767,72 & 1860,25 & 3108,61 \\
$\mathrm{~W}_{2} \mathrm{~K}_{2}$ & 521,85 & 1921,22 & 833,77 & 233,64 & 1367,11 & 2980,90 \\
$\mathrm{~W}_{3} \mathrm{~K}_{2}$ & 191,60 & 934,82 & 2226,64 & 282,63 & 2393,36 & 2212,68 \\
$\mathrm{~W}_{4} \mathrm{~K}_{2}$ & 2668,06 & 2967,52 & 2604,63 & 633,57 & 1521,68 & 1656,75 \\
$\mathrm{~W}_{1} \mathrm{~K}_{3}$ & 867,24 & 2597,78 & 2670,89 & 584,05 & 5508,64 & 2248,79 \\
$\mathrm{~W}_{2} \mathrm{~K}_{3}$ & 0,00 & 241,89 & 2346,46 & 489,82 & 96,61 & 1575,00 \\
$\mathrm{~W}_{3} \mathrm{~K}_{3}$ & 0,00 & 3641,26 & 1279,96 & 920,96 & 4430,93 & 3321,46 \\
$\mathrm{~W}_{4} \mathrm{~K}_{3}$ & 25,32 & 851,77 & 1479,68 & 36,14 & 1073,43 & 2029,86 \\
$\mathrm{~W}_{1} \mathrm{~K}_{4}$ & 0,00 & 2205,91 & 1420,46 & 378,81 & 2534,96 & 3916,43 \\
$\mathrm{~W}_{2} \mathrm{~K}_{4}$ & 103,95 & 3918,43 & 832,64 & 154,02 & 2704,75 & 3197,75 \\
$\mathrm{~W}_{3} \mathrm{~K}_{4}$ & 62,26 & 3819,79 & 1330,96 & 1035,54 & 4242,89 & 3331,82 \\
$\mathrm{~W}_{4} \mathrm{~K}_{4}$ & 32,97 & 2111,74 & 2856,36 & 596,07 & 3240,93 & 3333,50 \\
\hline
\end{tabular}


A Tabela 36 apresenta o resumo da análise de variância para produtividade comercial (PC), produtividade não comercial (PNC) e produtividade total (PT) do maracujazeiro amarelo.

Tabela 36. Resumo da análise de variância para produtividade comercial (PC), produtividade não comercial (PNC) e produtividade total (PT) do maracujazeiro amarelo cultivado sob diferentes níveis de irrigação com doses de potássio aplicadas via fertirrigação.

\begin{tabular}{|c|c|c|c|c|}
\hline \multirow[t]{2}{*}{ Causa de Variação } & \multirow[t]{2}{*}{ G.L } & \multicolumn{3}{|c|}{ Quadrado Médio (Valor de F) } \\
\hline & & PC & PNC & PT \\
\hline Blocos (B) & 3 & 453010 & 66,2 & 394577,5 \\
\hline Doses de $\mathrm{K}_{2} \mathrm{O}(\mathrm{K})$ & 4 & $15097787\left(20,5^{*}\right)$ & $674612,5\left(138,4^{*}\right)$ & $23873593\left(10,1^{*}\right)$ \\
\hline Resíduo (a) & 12 & 735236,4 & 4874,39 & 2359784 \\
\hline Parcelas & 19 & & & \\
\hline Lâminas de Irrigação (W) & 3 & $20130383\left(31,3^{*}\right)$ & $899483,3\left(89,1^{*}\right)$ & $31831457\left(23,3^{*}\right)$ \\
\hline Interação K x W & 12 & $7752632\left(12,0^{*}\right)$ & $116408,2\left(11,5^{*}\right)$ & $5508974\left(4,0^{*}\right)$ \\
\hline resíduo (b) & 45 & 642838,3 & 10086,39 & 1366157 \\
\hline Subparcelas & 79 & & & \\
\hline
\end{tabular}

* significativo ao nível de 5\% de probabilidade pelo teste $\mathrm{F}$.

ns não significativo ao nível de $5 \%$ de probabilidade pelo teste $\mathrm{F}$.

\subsubsection{Produtividade Comercial}

A produtividade comercial foi influenciada pelas doses de potássio, níveis de irrigação e interação desses dois fatores (Tabela 36). A Tabela 37 apresenta as produtividades comerciais médias obtidas para os diferentes tratamentos. A maior produtividade, de $14102 \mathrm{~kg} \cdot \mathrm{ha}^{-1}$, foi obtida com o tratamento $\mathrm{W}_{2} \mathrm{~K}_{0}$ e a menor produtividade, de $8734 \mathrm{~kg} \cdot \mathrm{ha}^{-1}$, para o tratamento $\mathrm{W}_{2} \mathrm{~K}_{2}$. As produtividades médias 
obtidas nesse trabalho são, de maneira geral, superiores a média nacional de 10000 kg.ha-1.

Tabela 37. Produtividade comercial $\left(\mathrm{kg} \cdot \mathrm{ha}^{-1}\right)$ do maracujazeiro cultivado sob diferentes níveis de irrigação e doses de potássio aplicadas via fertirrigação.

\begin{tabular}{cccccc}
\hline $\begin{array}{c}\text { Doses de } \mathrm{K}_{2} \mathrm{O} \\
(\mathrm{kg} \mathrm{planta})\end{array}$ & $63,3\left(\mathrm{~W}_{1}\right)$ & $118,5\left(\mathrm{~W}_{2}\right)$ & $171,5\left(\mathrm{~W}_{3}\right)$ & $220,4\left(\mathrm{~W}_{4}\right)$ & Média \\
\hline $0,00\left(\mathrm{~K}_{0}\right)$ & $(\mathrm{A}) 11072 \mathrm{ac}$ & $(\mathrm{A}) 14102 \mathrm{a}$ & $(\mathrm{AB}) 12149 \mathrm{a}$ & $(\mathrm{B}) 9562 \mathrm{a}$ & $\mathbf{1 1 7 2 1 a}$ \\
$0,200\left(\mathrm{~K}_{1}\right)$ & $(\mathrm{AB}) 12506 \mathrm{a}$ & $(\mathrm{B}) 12039 \mathrm{ab}$ & $(\mathrm{C}) 9556 \mathrm{~b}$ & $(\mathrm{~A}) 13506 \mathrm{~b}$ & $\mathbf{1 1 9 0 1 a}$ \\
$0,400\left(\mathrm{~K}_{2}\right)$ & $(\mathrm{A}) 8838 \mathrm{~b}$ & $(\mathrm{~A}) 8734 \mathrm{c}$ & $(\mathrm{A}) 9260 \mathrm{~b}$ & $(\mathrm{~B}) 12793 \mathrm{~b}$ & $\mathbf{9 9 0 6 b}$ \\
$0,600\left(\mathrm{~K}_{3}\right)$ & $(\mathrm{A}) 9853 \mathrm{bc}$ & $(\mathrm{A}) 9136 \mathrm{bc}$ & $(\mathrm{A}) 9446 \mathrm{~b}$ & $(\mathrm{~A}) 10976 \mathrm{ac}$ & $\mathbf{9 8 5 2 b}$ \\
$0,800\left(\mathrm{~K}_{4}\right)$ & $(\mathrm{A}) 10832 \mathrm{ac}$ & $(\mathrm{AB}) 12015 \mathrm{a}$ & $(\mathrm{B}) 13252 \mathrm{a}$ & $(\mathrm{AB}) 12339 \mathrm{bc}$ & $\mathbf{1 2 1 0 9 a}$ \\
Média & $(\mathbf{A}) \mathbf{1 0 6 2 0}$ & $(\mathbf{A}) \mathbf{1 1 2 0 5}$ & $(\mathbf{A}) \mathbf{1 0 7 3 2}$ & $(\mathbf{A}) \mathbf{1 1 8 3 5}$ & $\mathbf{1 1 0 9 8}$ \\
\hline
\end{tabular}

Médias na horizontal seguidas pela mesma letra maiúscula, não diferem significativamente ao nível de 5\% de probabilidade pelo teste de Tukey.

Médias na vertical seguidas pela mesma letra minúscula, não diferem significativamente ao nível de 5\% de probabilidade pelo teste de Tukey.

Teixeira (1989), obteve uma produtividade de $22260 \mathrm{~kg} \cdot \mathrm{ha}^{-1}$ em pomar comercial de maracujazeiro fertirrigado sob diferentes freqüências de aplicação de fertilizantes.

Os resultados obtidos estão de acordo com os encontrados por Sousa (2000), que obteve efeito significativo para doses de potássio, níveis de irrigação e interação desses fatores, porém com uma produtividade máxima de $44540 \mathrm{~kg} \cdot \mathrm{ha}^{-1}$, aplicando 0,675 kg de $\mathrm{K}_{2} \mathrm{O}$ e $944,22 \mathrm{~mm}$ de água, durante o primeiro ciclo do pomar utilizado nessa pesquisa. Martins (1998) obteve resposta significativa apenas para lâminas de irrigação, enquanto que para doses de potássio não houve efeito significativo, obtendo uma produtividade média de $33347 \mathrm{~kg} \cdot \mathrm{ha}^{-1}$ no primeiro ano da cultura. Teixeira (1989), obteve uma produtividade de $22260 \mathrm{~kg} \cdot \mathrm{ha}^{-1}$ em pomar comercial de maracujazeiro fertirrigado sob diferentes frequiências de aplicação de fertilizantes. 
Na Tabela 37 observa-se que os tratamentos $\mathrm{K}_{0}, \mathrm{~K}_{1}$ e $\mathrm{K}_{4}$ proporcionaram as maiores produtividades médias, com valores respectivamente de 11721, 11901 e 12109 kg.ha ${ }^{-1}$, não se diferindo ao nível de $5 \%$ de probabilidade pelo teste de Tukey. Verificase que as doses intermediárias $K_{2}$ e $K_{3}$ resultaram nas menores produtividades de 9906 e $9852 \mathrm{~kg} \cdot \mathrm{ha}^{-1}$. Isso pode ter ocorrido devido ao movimento do íon potássio no solo que, de acordo com Casarini \& Folegatti (1999), é tão móvel quanto o nitrogênio, podendo ocorrer lixiviação dependendo do volume de água aplicado no solo. Esse fato também foi evidenciado por Sousa (2000) que verificou perdas de potássio abaixo de 0,50 m e elevadas concentrações de potássio próximos de $0,70 \mathrm{~m}$ de profundidade, indicando a ocorrência de lixiviação, influenciada pelo volume de água. Na Tabela 10 verifica-se que houve uma grande precipitação pluviométrica somada ao volume de irrigação, podendo ter causado a lixiviação do potássio. Vivancos (1993) afirma que o potássio não é tão móvel no solo como o nitrogênio, porém penetra e permanece facilmente disponível no bulbo molhado, acumulando-se em seus bordos, podendo ser lixiviado.

\subsubsection{Produtividade não comercial}

A produtividade não comercial sofreu efeito significativo das doses de potássio, dos níveis de irrigação e da interação entre esses fatores (Tabela 36). $\mathrm{O}$ tratamento $\mathrm{W}_{3} \mathrm{~K}_{0}$ produziu maior quantidade de frutos não comerciais, igual a $972 \mathrm{~kg} \cdot \mathrm{ha}^{-1}$, e o tratamento $\mathrm{W}_{4} \mathrm{~K}_{3}$, produziu a menor quantidade de frutos não comerciais, igual a $286 \mathrm{~kg} \cdot \mathrm{ha}^{-1}$, conforme apresentado na Tabela 38. A ocorrência de frutos não comerciais pode ser 
devida a fatores genéticos associados com práticas de manejo, visto que as plantas foram podadas aos 500 dias após o transplantio das mudas, de maneira drástica. Santos (1999) concluiu que a poda drástica da metade dos ramos produtivos das plantas de maracujá amarelo, resultou em efeito negativo sobre o número de frutos apropriados para o mercado.

Tabela 38. Produtividade não comercial $\left(\mathrm{kg} \cdot \mathrm{ha}^{-1}\right)$ do maracujazeiro cultivado sob diferentes níveis de irrigação e doses de potássio aplicadas via fertirrigação.

\begin{tabular}{|c|c|c|c|c|c|}
\hline \multirow{2}{*}{$\begin{array}{c}\text { Doses de } \mathrm{K}_{2} \mathrm{O} \\
\left.\text { kg planta }^{-1}\right)\end{array}$} & \multicolumn{4}{|c|}{ Lâminas totais de irrigação (mm) } & \multirow[b]{2}{*}{ Média } \\
\hline & $63,3\left(\mathrm{~W}_{1}\right)$ & $118,5\left(\mathrm{~W}_{2}\right)$ & $171,5\left(\mathrm{~W}_{3}\right)$ & $220,5\left(\mathrm{~W}_{4}\right)$ & \\
\hline $0,00\left(\mathrm{~K}_{0}\right)$ & & & & & 1021d \\
\hline & & & & & $877 \mathrm{~cd}$ \\
\hline $0,400\left(\mathrm{~K}_{2}\right)$ & $8 b$ & & (A) & & $715 b c$ \\
\hline $0,600\left(\mathrm{~K}_{3}\right)$ & (A) $742 \mathrm{bc}$ & (B) $392 \mathrm{~b}$ & (B) $406 \mathrm{c}$ & $6 \mathrm{c}$ & $456^{\mathrm{a}}$ \\
\hline $0,800\left(\mathrm{~K}_{4}\right)$ & $(\mathrm{AB}) 501 \mathrm{c}$ & (A)702 a & $(\mathrm{AB}) 587 \mathrm{bc}$ & (B) $416 \mathrm{c}$ & 551ab \\
\hline Média & (A) 748 & (A) 713 & (A) 634 & (A) 801 & 724 \\
\hline
\end{tabular}

Médias na horizontal seguidas pela mesma letra maiúscula, não diferem significativamente ao nível de $5 \%$ de probabilidade pelo teste de Tukey.

Médias na vertical seguidas pela mesma letra minúscula, não diferem significativamente ao nível de 5\% de probabilidade pelo teste de Tukey.

A produtividade não comercial em função das doses de potássio apresentaram um efeito quadrático significativo ao nível de $5 \%$ de probabilidade pelo teste $\mathrm{F}$, com um coeficiente de determinação ${ }^{2}=0,90$, conforme apresentado na Figura 17. Nota-se que o aumento das doses de potássio ocasionou a redução na produção de frutos impróprios para o consumo, seguindo a mesma tendência verificada por Sousa (2000).

A produção não comercial decresceu a partir de $\mathrm{K}_{0}$, atingindo um valor mínimo de $456 \mathrm{~kg} \cdot \mathrm{ha}^{-1}$ para o tratamento $\mathrm{K}_{3}$, apresentando uma tendência de crescimento até o 
tratamento $\mathrm{K}_{4}$. Esse comportamento pode estar relacionado com o efeito competitivo do potássio com outros nutrientes, como afirma Malavolta (1980).

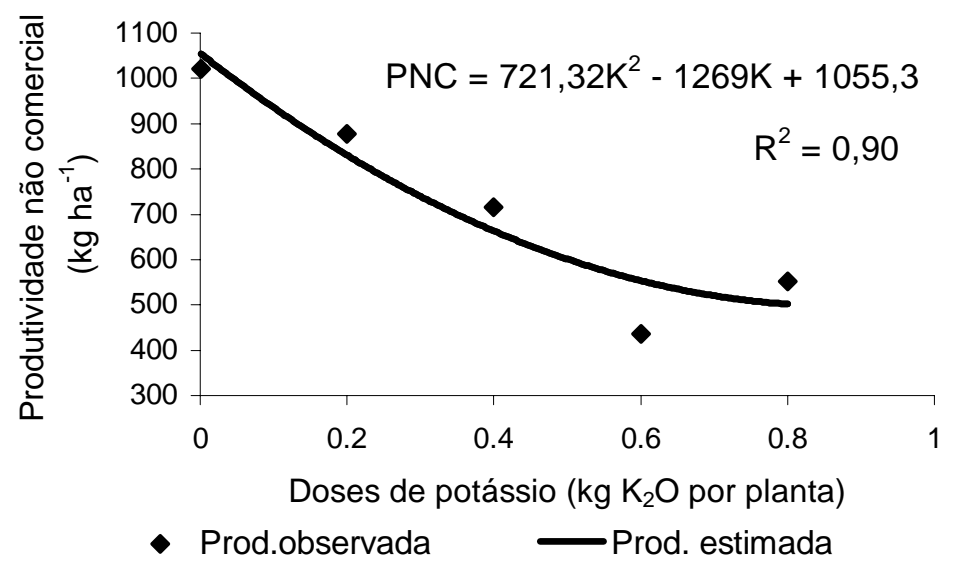

Figura 17 - Curva de produtividade não comercial média do maracujazeiro amarelo em função das doses de potássio.

\subsubsection{Produtividade total}

A produtividade total é a soma das produtividades comercial e não comercial e, da mesma forma que a produtividade comercial, sofreu efeito das doses de potássio, das lâminas de irrigação e da interação desses dois fatores, conforme apresentado na Tabela 36.

Os valores médios de produtividade total para os diferentes tratamentos estão apresentados na Tabela 39. A maior produtividade total (14806 kg.ha $\left.{ }^{-1}\right)$ maior foi obtida com o tratamento $\mathrm{W}_{2} \mathrm{~K}_{0}$. A menor produtividade total $\left(8879 \mathrm{~kg} \cdot \mathrm{ha}^{-1}\right)$ foi obtida com o tratamento $\mathrm{W}_{3} \mathrm{~K}_{2}$. 
Da mesma forma como observado na produtividade comercial, os tratamentos $\mathrm{K}_{0}, \mathrm{~K}_{1}$ e $\mathrm{K}_{4}$ proporcionaram as maiores produtividades totais médias, com valores de 12944, 12717 e $12846 \mathrm{~kg} \cdot \mathrm{ha}^{-1}$, respectivamente, não se diferindo ao nível de $5 \%$ de probabilidade pelo teste de Tukey. Verifica-se que as doses intermediárias $\mathrm{K}_{2}$ e $\mathrm{K}_{3}$ resultaram nas menores produtividades (10095 e $\left.10479 \mathrm{~kg} \cdot \mathrm{ha}^{-1}\right)$.

Tabela 39. Produtividade total $\left(\mathrm{kg} \mathrm{ha}^{-1}\right)$ do maracujazeiro cultivado sob diferentes níveis de irrigação e doses de potássio aplicadas via fertirrigação.

\begin{tabular}{cccccc}
\hline Doses de $\mathrm{K}_{2} \mathrm{O}$ & \multicolumn{5}{c}{ Lâminas totais $(\mathrm{mm})$} \\
$\left(\mathrm{kg} \mathrm{planta}^{-1}\right)$ & $63,3\left(\mathrm{~W}_{1}\right)$ & $118,5\left(\mathrm{~W}_{2}\right)$ & $171,5\left(\mathrm{~W}_{3}\right)$ & $220,5\left(\mathrm{~W}_{4}\right)$ & Média \\
\hline $0,00\left(\mathrm{~K}_{0}\right)$ & $(\mathrm{A}) 11980 \mathrm{ab}$ & $(\mathrm{A}) 14806^{\mathrm{a}}$ & $(\mathrm{A}) 13230 \mathrm{a}$ & $(\mathrm{A}) 11763 \mathrm{a}$ & $\mathbf{1 2 9 4 4 b}$ \\
$0,200\left(\mathrm{~K}_{1}\right)$ & $(\mathrm{A}) 13274 \mathrm{a}$ & $(\mathrm{A}) 12936 \mathrm{ab}$ & $(\mathrm{B}) 10160 \mathrm{~b}$ & $(\mathrm{~A}) 14499 \mathrm{a}$ & $\mathbf{1 2 7 1 7 b}$ \\
$0,400\left(\mathrm{~K}_{2}\right)$ & $(\mathrm{A}) 9650 \mathrm{~b}$ & $(\mathrm{~A}) 9661 \mathrm{bc}$ & $(\mathrm{A}) 8879 \mathrm{~b}$ & $(\mathrm{~A}) 12192 \mathrm{a}$ & $\mathbf{1 0 0 9 5 a}$ \\
$0,600\left(\mathrm{~K}_{3}\right)$ & $(\mathrm{A}) 10478 \mathrm{~b}$ & $(\mathrm{~A}) 9545 \mathrm{c}$ & $(\mathrm{A}) 10232 \mathrm{~b}$ & $(\mathrm{~A}) 11661 \mathrm{a}$ & $\mathbf{1 0 4 7 9 a}$ \\
$0,800\left(\mathrm{~K}_{4}\right)$ & $(\mathrm{A}) 11778 \mathrm{ab}$ & $(\mathrm{A}) 12782 \mathrm{abc}$ & $(\mathrm{A}) 14042 \mathrm{a}$ & $(\mathrm{A}) 12785 \mathrm{a}$ & $\mathbf{1 2 8 4 6 b}$ \\
Média & $(\mathbf{A}) \mathbf{1 1 4 3 2}$ & $(\mathbf{A}) \mathbf{1 1 9 4 6}$ & $(\mathbf{A}) \mathbf{1 1 3 0 8}$ & $(\mathbf{A}) \mathbf{1 2 5 8 0}$ & $\mathbf{1 1 8 1 6}$ \\
\hline
\end{tabular}

Médias na horizontal seguidas pela mesma letra maiúscula, não diferem significativamente ao nível de 5\% de probabilidade pelo teste de Tukey.

Médias na vertical seguidas pela mesma letra minúscula, não diferem significativamente ao nível de 5\% de probabilidade pelo teste de Tukey. 


\section{CONCLUSÕES}

Com base nos resultados obtidos pode-se concluir que:

a) houve efeito significativo das lâminas de irrigação sobre o diâmetro do caule e a área foliar do maracujazeiro amarelo. O comprimento de internós não foi influenciado pelos tratamentos testados;

b) o peso do fruto, a densidade do suco, a espessura da casca e o rendimento de suco foram influenciados significativamente pelas lâminas de irrigação, pelas doses de potássio e pela interação entre esses fatores. Não houve efeito significativo dos tratamentos sobre os sólidos solúveis totais, $\mathrm{pH}$ e acidez total titulável do suco;

c) não houve efeito significativo dos tratamentos sobre o diâmetro do fruto. $\mathrm{O}$ comprimento de fruto foi afetado significativamente pela interação entre lâminas de irrigação e doses de potássio;

d) as concentrações foliares de potássio, magnésio e manganês foram influenciadas significativamente pelas lâminas de irrigação e pelas doses de potássio;

e) as concentrações foliares de boro e ferro sofreram efeito significativo apenas da interação entre as lâminas de água e as doses de nitrogênio; 
f) não houve efeito significativo dos tratamentos sobre as concentrações foliares de nitrogênio, fósforo, cálcio, enxofre, cobre e zinco;

g) a produção comercial foi influenciada significativamente pelos tratamentos testados, apresentando o maior valor de $14102 \mathrm{~kg} \cdot \mathrm{ha}^{-1}$ obtida com a aplicação de 118,5 mm de água (tratamento $\mathrm{W}_{2}$ ) combinada com dose nula de potássio (tratamento $\mathrm{K}_{0}$ ), e a menor produção comercial igual de $8734 \mathrm{~kg} \cdot \mathrm{ha}^{-1}$ obtida com a aplicação de 118,5 mm de água (tratamento $\mathrm{W}_{2}$ ) com $0,200 \mathrm{~kg}$ de $\mathrm{K}_{2} \mathrm{O}$ por planta (tratamento $\mathrm{K}_{2}$ );

h) a produção não comercial foi influenciada significativamente pelos tratamentos testados, com tendência quadrática de redução com o aumento das doses de potássio, apresentando o maior valor médio $\left(1021 \mathrm{~kg} \cdot \mathrm{ha}^{-1}\right)$ para o tratamento $\mathrm{K}_{0}(0,00$ kg.planta ${ }^{-1}$ de $\left.\mathrm{K}_{2} \mathrm{O}\right)$ e o menor valor médio $\left(456 \mathrm{~kg} \cdot \mathrm{ha}^{-1}\right)$ com o tratamento $\mathrm{K}_{3}$ $\left(0,600 \mathrm{~kg} \cdot\right.$ planta $^{-1}$ de $\left.\mathrm{K}_{2} \mathrm{O}\right)$;

i) houve efeito significativo dos tratamentos sobre a produção total de frutos, obtendose o maior valor (14806kg.ha-1) com a combinação de 118,5 mm de água (tratamento $\mathrm{W}_{2}$ ) e dose nula de potássio (tratamento $\left.\mathrm{K}_{0}\right)$ e o menor valor $\left(8879 \mathrm{~kg} \cdot \mathrm{ha}^{-1}\right)$ com a aplicação de $171,5 \mathrm{~mm}$ de água (tratamento $\mathrm{W}_{3}$ ) e $0,400 \mathrm{~kg}$ de $\mathrm{K}_{2} \mathrm{O}$ por planta (tratamento $\mathrm{K}_{2}$ ). 


\section{REFERÊNCIAS BIBLIOGRÁFICAS}

AGUIRRE, A.C.P. Nutrição mineral do maracujá amarelo ( Passiflora edulis Sims f. flavicarpa Deg). Piracicaba, 1977. 116p. Dissertação (Mestrado) - Escola Superior de Agricultura “Luiz de Querioz”, Universidade de São Paulo.

ARAUJO, C. M.; GAVA, A. J.; ROBBS, P. G. et al. Características industriais do maracujá (Passiflora edulis f. flavicarpa) e maturação do fruto. Pesquisa Agropecuária Brasileira, v.9, n.9, p.65-69, 1974.

BABEAR, S.A. Mecanismo de absorção do potássio por plantas no solo. In: YAMADA, T. Potássio na agricultura brasileira. Piracicaba, Instituto da Potassa \& Fosfato, 1982. p.213-226.

BAUMGARTNER, J.G. Nutrição e adubação. In: RUGGIERO, C. (Ed.) Maracujá. Ribeirão Preto: Legis Summa, 1987. p. 86-96.

BAUMGARTNER, J. G.; LOURENÇO, R. S.; MALAVOLTA, E. Estudos sobre a nutrição mineral e adubação do maracujazeiro (Passiflora edulis Sims f. flavicarpa Deg.). V. Adubação mineral. Científica, v. 6, n.3, p.361-367, 1978.

CARRIJO, O. A.; SILVA, W. L. C.; MAROUELLI, W. A. et al. Tendências e desafios da fertirrigação no Brasil. In: FOLEGATTI, M.V. (Coord). Fertirrigação: citros, flores e hortaliças. Guaíba: Agropecuária, 1999. cap.1, p.155-169. 
CARVAlHO, A. J. C. de; MARTINS, D. P.; MONNERAT, P. H. et al. Adubação nitrogenada e irrigação no maracujazeiro amarelo. I. Produtividade e qualidade dos frutos. Pesquisa Agropecuária Brasileira, v.35, n.6, p.1101-1108, 2000.

CARVALHO, L. C. Estudo da distribuição do sistema radicular do maracujazeiro amarelo. In: CONGRESSO BRASILEIRO DE FRUTICULTURA,9., Campinas, 1987. Anais. Campinas: Sociedade Brasileira de Fruticultura, 1988. v.2, p.609-612.

CASARINI, E.; FOLEGATTI, M.V. Aspectos relevantes na fertirrigação de flores e hortaliças. In: FOLEGATTI, M.V. (Coord). Fertirrigação: citros, flores e hortaliças. Guaíba: Agropecuária, 1999. cap.5, p.355-441.

COELHO, E. F. Irrigação. In: LIMA, A. A. (Coord.) O cultivo do maracujá. Cruz das Almas: Embrapa Mandioca e Fruticultura,1999. p.48-54 (Circular Técnica, 35).

COELHO, M. B., CORDEIRO, G. G. Comparação entre os métodos de irrigação por sulco e gotejo em maracujá. In: SEMINÁRIO LATINO-AMERICANO DE IRRIGAÇÃO POR GOTEJAMENTO, 3, Campinas, 1979. Campinas: s.ed., 1979. p.491-498.

COLAUTO, N.M.; MANICA, I.; RIBOLDI, J. et al. Efeito do nitrogênio, fósforo e potássio, sobre a produção, qualidade e estado nutricional do maracujazeiro amarelo. Pesquisa Agropecuária Brasileira, v.21, n.7, p.691-695, 1986.

FERRI, M. G. Fisiologia Vegetal. São Paulo: EDUSP, 1979. v.1. 331p.

FIGUEIREDO, R. W.; SESSA, M. C. M.; HOLANDA, L. F. F. et al. Estudo das características físicas e do rendimento do maracujá amarelo. In: CONGRESSO BRASILEIRO DE FRUTICULTURA, 9, Campinas, 1987. Anais. Campinas: Sociedade Brasileira de Fruticultura, 1988. v.2, p.613-617. 
FNP CONSULTORIA \& COMÉRCIO Agrianual 2000: anuário da agricultura brasileira. São Paulo, 2000. p.398-406: Maracujá.

FNP CONSULTORIA \& COMÉRCIO Agrianual 2002: anuário da agricultura brasileira. São Paulo, 2002. p.402-408: Maracujá.

GURNAH, A.M.; GACHANJA, S.P. Spacing and pruning of purple passion fruit. Tropical Horticulturae, v.61, n.2, p.143-147, apr. 1984.

HAAG, H.P; OLIVEIRA, G.D; BORDUCHI, A.S. et al. Absorção de nutrientes por duas variedades de maracujá. Anais da Escola Superior de Agricultura "Luis de Queiroz”, v. 30, p. 267-279, 1973.

HAENDLER, L. La possiflora: as composition chimique et sés possibilites de transformation. Fruits. v.20, n. 5, p.235-245, 1965.

KLIEMANN, H. J; CAMPELO JÚNIOR, J. H; AZEVEDO, J. A. et al. Nutrição mineral e adubação do maracujazeiro. In: H.P. HAAG. Nutrição Mineral e adubação de fruteiras tropicais. Campinas: Fundação Cargill, 1986, p.247-284.

LIMA, A. de A. A Pesquisa no Brasil com a cultura do maracujá. Cruz das Almas: EMBRAPA-CNPMF, 1994. 14p (EMBRAPA-CNPMF, 55).

MALAVOLTA, E, HAAG., MELLO, BRASIL SOBRINHO. Nutrição mineral e adubação de plantas cultivadas. São Paulo: Pioneira , 1974, 727p.

MALAVOLTA, E. Elementos de nutrição mineral de plantas. Piracicaba: Pioneira, $1980,215 \mathrm{p}$. 
MALAVOLTA, E. Nutrición y fertilización del maracayá. CENA - Piracicaba - SP Brasil, 1994, 52p.

MALAVOLTA, E; VITTI, G. C.; OLIVEIRA, S. A. Avaliação do estado nutricional das plantas. Piracicaba: Associação Brasileira para a Pesquisa do Potássio e do Fosfato, 1989. 201p.

MANICA, I. Fruticultura tropical: Maracujá. São Paulo: Ed. Agronômica Ceres, 1981. 151p.

MARTINS, D.P. Resposta do maracujazeiro amarelo (Passiflora edulis Sins var. flavicarpa Deg.) a lâminas de irrigação e doses de nitrogênio e potássio. Campos dos Goytacazes, 1998. 84p. Tese (Doutorado) - Universidade Estadual do Norte Fluminense.

MARTIN, F. W.; NAKASONE, H.Y. The edible species of passiflora. Economic Botany, v.24, n.3, p.333-343, 1970.

MATSUMOTO, S.N.; SÃO JOSÉ, A.R. Fatores que afetam a frutificação do maracujazeiro ácido. In: SÃO JOSÉ, A.R. A cultura do maracujá no Brasil. Jaboticabal: FUNEP, 1991. p.109-123.

MEDINA, J.C.; GARCIA, J.L.M.; LARA, L.C.C. et al. Maracujá: da cultura ao processamento e comercialização. Campinas: Secretaria da Agricultura e Abastecimento/ ITAL, 1980, 207p.

MELETTI, L. M.M. Maracujá: produção e comercialização em São Paulo. Boletim Técnico. Instituto Agronômico, n.158, p.2-26, 1996.

MELETTI, L. M. M.; MAIA, M. L. Maracujá: produção e comercialização. Boletim Técnico. Instituto Agronômico de Campinas, n. 181, p.2-26, 1999. 
MENZEL, C.M; SIMPSON, D.R; PRINCE, G.H. Effect of foliar applied nitrogen during winter on growth, nitrogen content and production of passion fruit. Scientia Horticulturae, v.28, p.339-346, 1986a.

MENZEL, C.M; SIMPSON, D.R.; DOWLING, A.J. Water relations in passion fruit: effect of moisture stress on growth, flowering and nutrient uptake. Scientia Horticultural, v.29, p.239-249, 1986 b.

MENZEL, C. .M.; SIMPSON, D. D.; WINKS, C.W. Effect of temperaturae on growth, flowering and nutrient uptake of three passion fruit cultivars under low irradiance. Scientia Horticulturae, v.31, p.259-268, 1987.

MENZEL, C. .M.; SIMPSON, D. R. Effect of continuous shading on growth, flowering and nutrient uptake of passion fruit. Scientia Horticulturae, v.35, p.77-88,1988.

MENZEL, C. .M.; SIMPSON, D. R. Effect of intermittent shading on growth, flowering and nutrient uptake of passion fruit. Scientia Horticulturae, v.41, p.83-86,1989.

MENZEL, C. .M.; SIMPSON, D. R. Passion fruit. In: SCHAFFER, B.; ANDERSEN, P.C. Handbook of environmental physioly of fruit crop. Boca Ratton: CRC, 1994. cap.10, v.2, p.225-241.

MÜLLER, C. H.;. Efeitos de doses de sulfato de amônio e de cloreto de potássio sobre a produtividade e sobre a qualidade de maracujás colhidos em épocas diferentes. Viçosa, 1977. 89p. Dissertação (Mestrado) - Universidade Federal de Viçosa.

MÜLlER, C. H.;. PINHEIRO, R.V.R.; CASALI, V.W.D. et al. Efeitos de doses de sulfato de amônio e de cloreto de potássio sobre a produtividade e sobre a qualidade de maracujás colhidos em épocas diferentes. Revista Ceres, v.26, n.143, p.48-64, $1979 b$. 
NASCIMENTO, T. B. do. Qualidade do maracujá amarelo produzido em diferentes épocas no sul de Minas Gerias. Lavras, 1996. 56p. Dissertação (Mestrado) Universidade Federal de Lavras.

NASCIMENTO, T. B. do.; RAMOS, J. D.; MENESES, J. B. Características físicoquímicas do maracujá amarelo (Passiflora edulis Sims f. flavicarpa Degener) pproduzido em diferentes épocas. Revista Brasileira de Fruticultura, v.20, n.1, p.33-38, 1988.

NETO, L.G.; BEZERRA, J.E.F.; ABRAMOF, L. et al. Cultivo do maracujá. Recife: Secretaria. Da Agricultura. 1983, 40p. (Boletim Técnico, 9).

OLITA, A. F. Os métodos de irrigação. 11.ed. São Paulo: Nobel, 1984. 267p.

OLIVEIRA, J. C. de; FERREIRA, F. R.; RUGGIERO, C., et al. Caracterização e avaliação de germoplasma de Passiflora edulis. In: CONGRESSO BRASILEIRO DE FRUTICULTURA, 9, Campinas, 1987. Anais. Campinas: Sociedade Brasileira de Fruticultura, 1988. v.2, p.585-590.

PAPADOPOULOS, I. Situação atual e perspectivas para o futuro. In: FOLEGATTI, M.V. (Coord). Fertirrigação: citros, flores e hortaliças. Guaíba: Agropecuária, 1999. cap.1, p.11-155.

PIZZOL, S.J.S. de.; SILVA, T.H.S.; GONÇALVES, G. et al. O maracujá no Brasil. Preços Agrícolas, p.22-23, jun., 1998.

PIZZOL, S.J.S. de.; WILDER, A.; ELEUTÉRIO, R.C. et al. Mercado Norte-americano de maracujá. Preços Agrícolas, p.41, fev., 2000. 
PRIMAVESI, A.C.P.A.; MALAVOLTA, E. Estudos sobre a nutrição mineral do maracujá amarelo. VI. Efeito dos macronutrientes no desenvolvimento e composição mineral das plantas. Anais da Escola Superior de Agricultura "Luiz de Queiroz", v.37, n.2, p.609-630, 1980.

RAIJ, B. van. Fertilidade do solo e adubação. Piracicaba: CERES/ POTAFOS, 1991, 343p.

RITZINGER, R.; MANICA, I.; RIBOLDI, J. Efeito do espaçamento e da época de colheita sobre a qualidade do maracujá amarelo. Pesquisa Agropecuária Brasileira, v.24, n.2, p.241-245, 1989.

RIZZI, L.C.; RABELLO, L. R.; MOROZINI FILHO, W. et al. Cultura do maracujá azedo. Campinas, CATI, 1998. 54p (boletim técnico, 235).

RODRIGUEZ, O. A importância do potássio em citricultura. In: YAMADA, T. Potássio na agricultura brasileira. Piracicaba: Instituto da Potassa \& Fosfato, 1982, p.507-513.

RUGGIERO, C (Ed). Maracujá. Ribeirão Preto: Legis Summa, 1987. 246p.

RUGGIERO, C.; SÃO JOSÉ, A.R.; VOLPE, C.A. et al. Maracujá para exportação: aspectos técnicos da produção. Brasília: EMBRAPA-SPI, 1996, 64p. (Publicações Técnicas FRUPEX, 19)

SANTOS, C. J. O. Estudo da poda drástica e outras variáveis agronômicas sobre o comportamento produtivo do maracujazeiro amarelo Areia, 1999. 50p. Monografia (Graduação) - Universidade Federal da Paraíba.

SCHULTZ, A. Botânica sistemática. 3.ed. Porto Alegre: Globo, 1968, 215p. 
SILVA, A.C.; SÃO JOSÉ, A.R. Classificação botânica do maracujazeiro. In: SÃO JOSÉ, A.C. (Ed). Maracujá, produção e mercado. Vitória da Conquista, Universidade Estadual do Sudoeste da Bahia, 1994. 255p.

SJOSTROM, G.; ROSA, J. F. L. Estudo sobre as características físicas e composição química do maracujá ácido Passiflora edulis Sims f. flavicarpa Deg. cultivado no município de Entre Rios, Bahia. In: CONGRESSO BRASILEIRO DE FRUTICULTURA, 4, Salvador, 1978. Anais. Cruz das Almas: Sociedade Brasileira de Fruticultura, 1978. p.265-273.

SOUSA, V. F. Níveis de irrigação e doses de potássio aplicados via fertirrigação por gotejamento no maracujazeiro amarelo (Passiflora edulis Sims. f. flavicarpa Deg). Piracicaba, 2000. 178p. Tese (Doutorado) - Escola Superior de Agricultura "Luiz de Queiroz" Universidade de São Paulo.

SOUZA, J.S.I.; MELETTI, L.M.M. Maracujá: espécies, variedades, cultivo. Piracicaba: FEALQ, 1997. 179p.

STAVELY, G.W.; WOLSTENHOLME, B.N. Effects of water stress on growth and flowering of Passiflora edulis (Sims) grafted to P.Caerulea L. Acta Horticulturae, n.275, p.251-258, 1990.

TEIXEIRA, C.G. Maracujá: cultura. In: INSTITUTO DE TECNOLIGIA DE ALIMENTOS. Maracujá: cultura, matéria-prima, processamento e aspectos econômicos. 2.ed. Campinas: Secretaria da Agricultura e Abastecimento/ITAL, 1994. cap.1, p.3-131.

TEIXEIRA, D. M. M.;. Efeitos de vários níveis de fertrirrigação na cultura maracujazeiro amarelo (Passiflora edulis var. flavicarpa). Piracicaba, 1989. 100p. 
Dissertação (Mestrado) - Escola Superior de Agricultura "Luiz de Queiroz" Universidade de São Paulo.

TOCCHINI, R. P.; NISIDA, A L. A. C.; HASHIZUME, T. et al.. Processamento: produtos, caracterização e utilização. In: INSTITUTO DE TECNOLIGIA DE ALIMENTOS. Maracujá: cultura, matéria-prima, processamento e aspectos econômicos. 2.ed. Campinas: Secretaria da Agricultura e Abastecimento/ITAL, 1994. cap.3, p.161-195.

VASCONCELOS, M.A.S. O cultivo do maracujá doce. In: SÃO JOSÉ, A.R. (Ed). Maracujá: produção e mercado. Vitória da Conquista: DFZ/UESB, p.71-83, 1994.

VERAS, M.C. Fenologia, produção e caracterização físico-química dos maracujazeiros ácido (Passiflora edulis f. flavicarpa Deg) e doce (Passiflora alata Dryand) nas condições de Cerrado de Brasília-DF. Lavras, 1997. 105p. Dissertação (Mestrado) - Universidade Federal de Lavras.

VILLA NOVA, N.A.; ANGELOCCI, L.R.; MARIN, F.R. et al. Determinação do índice de área foliar de lima ácida "Tahiti” e de seringueira por interceptação da radiação solar com uso de luxímetro de baixo custo. (no prelo).

VIVANCOS, A. D. Fertirrigación. Madrid: Mundi-Prensa, 1993, 215p. 